\title{
CAROTENOIDS AFFECT THE STRUCTURE AND FUNCTIONS OF THE CYANOBACTERIAL PHOTOSYNTHETIC COMPLEXES
}

\author{
Ph.D. Thesis
}

\section{Sindhujaa Vajravel}

Supervisors: Dr. Zoltán Gombos \& Dr. Tünde N. Tóth

\author{
Biological Research Centre of the Hungarian Academy of Sciences \\ Institute of Plant Biology \\ Laboratory of Plant Lipid Function and Structure
}

University of Szeged

Doctoral School of Biology

Szeged, 2018 


\section{Contents}

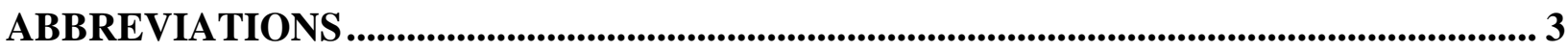

1. INTRODUCTION ......................................................................................................................... 5

1.1. General process of cyanobacterial photosynthesis ....................................................................5

1.2. The light harvesting complex of cyanobacteria ................................................................................. 7

1.2.1. The structure of PBS .................................................................................................................... 7

1.2.2. PBS degradation process............................................................................................................... 8

1.3. Cyanobacterial photosystems: structure and function .................................................................... 11

1.3.1. Photosystem I................................................................................................................................... 11

1.3.2. Photosystem II ...................................................................................................................... 14

1.4. The structure, function, and biosynthesis of carotenoids............................................................. 16

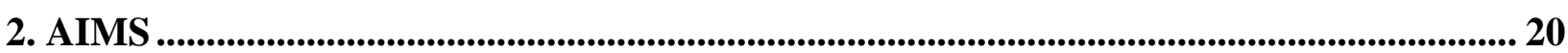

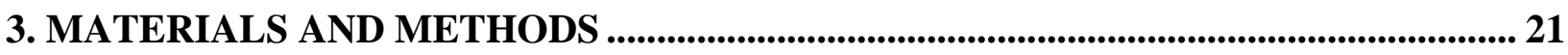

3.1. Organisms and growth conditions .......................................................................................... 21

3.2. Construction of Synechocystis PCC 6803 mutants ...................................................................... 22

3.3. Measurement of cell density and chlorophyll concentration ....................................................... 22

3.4. 77 K fluorescence emission spectroscopy ……....................................................................... 23

3.5. Circular-dichroism spectroscopy ...................................................................................................... 23

3.6. Time-resolved fluorescence spectroscopy ……………................................................................... 24

3.7. Photosynthetic oxygen polarography................................................................................... 24

3.8. Isolation of thylakoid membranes and cytosolic fraction ........................................................... 25

3.9. Sucrose density gradient separation of pigment-protein complexes........................................... 25

3.9.1. Isolation of phycobilisome.............................................................................................................. 25

3.9.2. Isolation of photosystem I................................................................................................................. 26

3.10. Protein analysis ............................................................................................................................. 26

3.10.1. Determination of protein concentration and SDS-PAGE .................................................... 26

3.10.2. BN- and CN-PAGE...................................................................................................... 26

3.11. Chromatographic techniques ..................................................................................................... 27

3.11.1. HPLC ............................................................................................................................................. 27

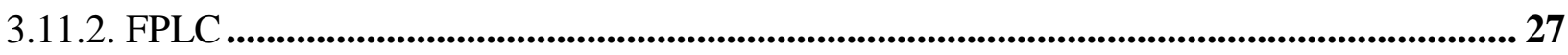

3.12. Statistical analysis ........................................................................................................................ 28

4. RESULTS AND DISCUSSIONS .............................................................................................. 29

4.1. $\beta$-carotene influences the phycobilisome structure ......................................................................... 29 
4.1.1. Fluorescence emission of cells with modified carotenoid composition or lack of photosystems

4.1.2. Protein analysis of the cytosolic fraction from crtB cells ............................................... 32

4.1.3. High light-induced damage in carotenoid deficient mutants.............................................. 34

4.1.4. Effect of glucose on crtH cells ....................................................................................... 39

4.1.5. Additional myxoxanthophyll deficiency in crtH cells .................................................. 40

4.1.6. Nitrogen shortage induced PBS degradation in crtH and crtB strains ............................. 41

4.2. Zeaxanthin and echinenone modify the structure of PSI trimer .......................................... 48

4.2.1. Pigment analysis of cells and PSI complexes ................................................................. 48

4.2.2. Testing the PSI organization by in vivo spectroscopic methods ........................................ 51

4.2.3. Protein analysis of the thylakoid membrane .......................................................................... 55

4.2.4. Spectroscopic investigation of the PSI complexes ............................................................5 59

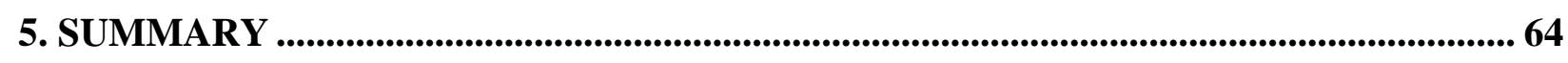

6. SUMMARY IN HUNGARIAN...................................................................................... 70

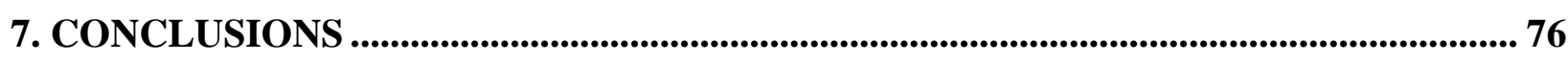

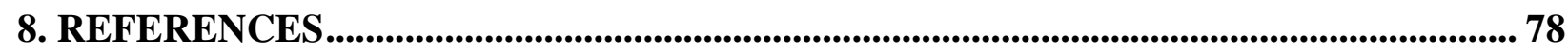

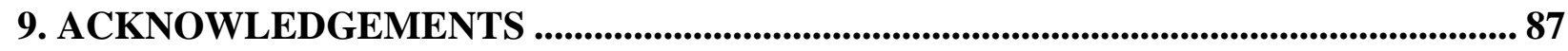

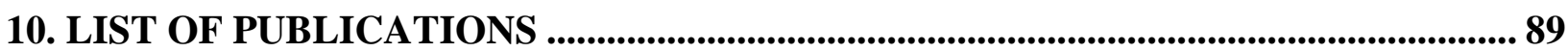




\section{ABBREVIATIONS}

${ }^{1} \mathrm{O}_{2}$ - Singlet oxygen

APC - Allophycocyanin

BN/CN/SDS-PAGE - Blue and clear native/sodium dodecyl sulfate polyacrylamide gel electrophoresis

CD - Circular dichroism

Chl - Chlorophyll

Cyt $b_{6} f$ - Cytochrome $b_{6} \mathrm{f}$

DAS - Decay associated spectrum

$\beta$-DM - n-Dodecyl $\beta$-D-maltoside

DMBQ - 2,6-Dimethylbenzoquinone

EDTA - Ethylenediaminetetraacetic acid

EET - Excitation energy transfer

FNR - Ferredoxin/NADP ${ }^{+}$oxidoreductase

FPLC - Fast protein liquid chromatography

HPLC - High performance liquid chromatography

LAHG - Light-activated heterotrophic growth

$\mathrm{L}_{\mathrm{R}} 30$ - $30 \mathrm{kDa}$ rod linker proteins

$\mathrm{L}_{\mathrm{R}} 33$ - $33 \mathrm{kDa}$ rod linker proteins

LMC - Core membrane linker

LRC - Linker rod-core

LWC - Long wavelength chlorophyll

OD - Optical density

PAG - Photoautotrophic growth

PBS - Phycobilisome

PC - Phycocyanin 
PMG - Photomixotrophic growth

PPFD - Photosynthetic photon flux density

PQ - Plastoquinone

PSI and PSII - Photosystem I and II

ROS - Reactive oxygen species

TE - Terminal emitter 


\section{INTRODUCTION}

\subsection{General process of cyanobacterial photosynthesis}

Cyanobacteria are ecologically important prokaryotes that also serve as the popular model organism for studying photosynthesis. The approximately 2.3 billion years ago, cyanobacteria started performing an oxygenic photosynthesis by utilizing the visible range of light (300-700 $\mathrm{nm}$ ) (Yagishita et al 1997). These prokaryotic photosynthetic organisms are the ancestors of plastids in algae and plants due to the evolutionary event of endosymbiosis (HohmannMarriott \& Blankenship, 2011). Since cyanobacteria show a strong homology with the photosynthetic machinery of eukaryotes, it can be used as a suitable model organism to study different aspects and regulation of photosynthesis that is often difficult to approach in higher plants and algae. The further advantages of cyanobacteria are its rapid growth under laboratory culture conditions and its immense metabolic flexibility (Eberhard et al., 2008). Due to its simplicity of single cell system, it is easy to manipulate genetically when compared to the complex multicellular systems. These advantages are also making the cyanobacterium as an important model organism to conduct basic and applied research in the field of photosynthesis, abiotic stress responses and many other cellular processes.

Photosynthesis is a process to convert light energy into chemical energy providing the basic energy source for life on earth and for the oxygenic atmosphere. Similarly to all eukaryotic photosynthetic organisms, in cyanobacteria, the photosynthetic electron transport occurs in the thylakoid membrane. The thylakoids accommodate the photosystem I (PS I), photosystem II (PS II) as reaction centers (RCs), phycobilisome (PBS), cytochrome $b_{6} f(C y t$ $b_{6} f$ ), and ATP synthase as the major photosynthetic protein complexes. The small electron transport molecules, such as plastoquinone (PQ) pool, plastocyanin (PC), cytochrome $\mathrm{c}_{6}$, and 
ferredoxin (Fd) (Fig. 1) are also involved in the electron transport mechanism (Eberhard et al 2008, Hohmann-Marriott \& Blankenship 2011).

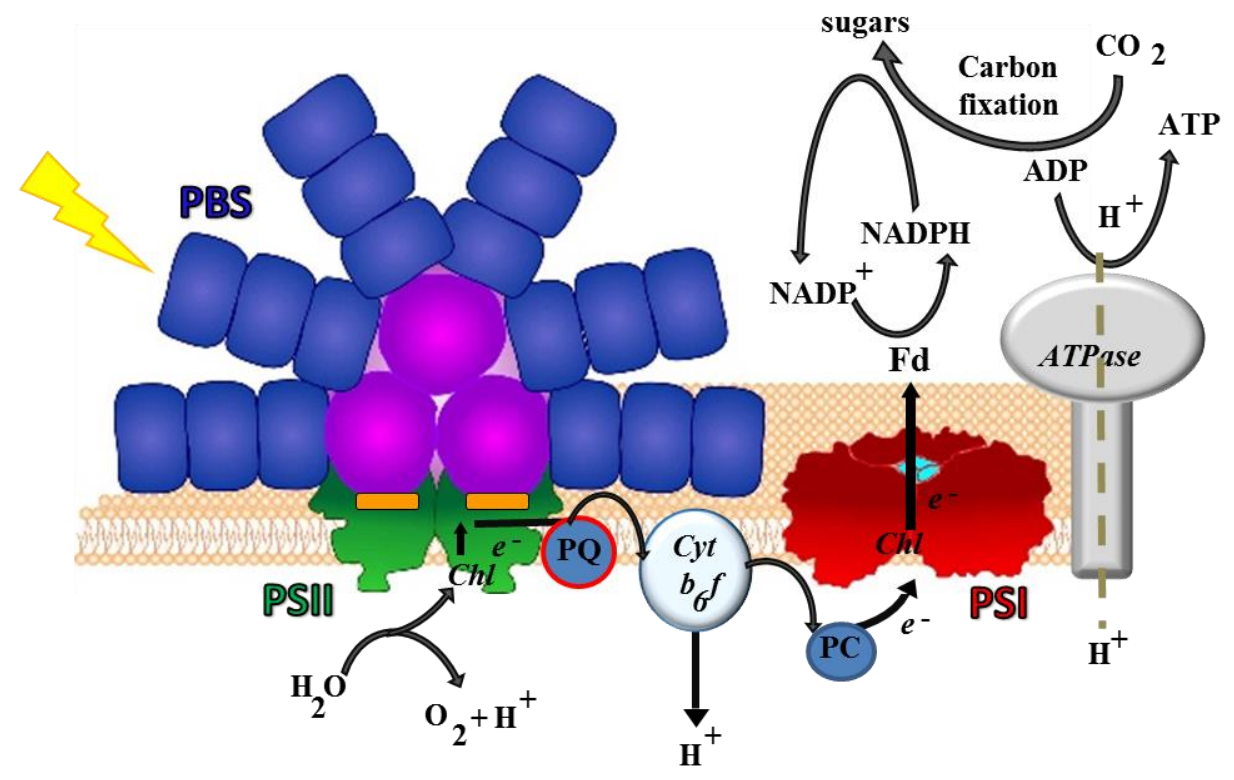

Figure 1. Schematic representation of the photosynthetic electron transport in cyanobacteria. Abbreviations: PBS, Phycobilisome; PSI, Photosystem I; PSII, Photosystem II; PQ, Plastoquinone; Cyt b6f, Cytochrome b6f; PC, Plastocyanin; Fd, Ferredoxin; ATPase, ATP synthase.

Initial event of cyanobacterial photosynthesis is the absorption of photons by the lightharvesting antennae, the PBS. The excitation energy is transferred from the PBS to the chlorophyll $a(\mathrm{Chl} a)$ molecules of PSII reaction center where the charge separation occurs and initiates electron transport. These electrons reduce PQ and transferred from PQ pool to the Cyt $b_{6} f$ complex and to a mobile electron carrier, the PC (Fig. 1). PC reduces the photooxidized PSI reaction center Chl $a$ molecules; the oxidized form of PSI reaction center is induced by the electron transfer from PSI to reduce NADPH. The above-described electron transport mechanism plays a major role in the proton transfer across the thylakoid membrane, and the created proton motive force is used by the ATPase to convert ADP to ATP. The produced ATP and NADPH are subsequently used to produce carbohydrates in the CalvinBenson cycle (carbon-fixation reactions). 


\subsection{The light harvesting complex of cyanobacteria}

\subsubsection{The structure of PBS}

In cyanobacteria, red algae and glaucophytes, the main light-harvesting antenna is the PBS: a giant, multi pigment-protein complex, which is often the most abundant protein complex of the cell. The PBS contains 200-500 phycobilin pigments covalently bound to apoproteins, the so-called phycobiliproteins which are heterodimers composed of $\alpha$ and $\beta$ subunits. Based on the spectral properties, the phycobiliproteins are divided into three groups: phycoerythrins, phycocyanins, and allophycocyanin. These phycobiliproteins are combined to form a hierarchically ordered PBS megacomplex by the support of specific linker proteins (MacColl 1998, Ughy \& Ajlani 2004). Depending on the species and growth conditions, several types of PBSs can be found. The most common form is the hemidiscoidal type of PBSs which possess six to eight peripheral rods attached to the central allophycocyanin (APC) core complex (Chang et al 2015, Watanabe \& Ikeuchi 2013).

Among cyanobacteria, Synechocystis sp. PCC 6803 (hereafter Synechocystis) is one of the most widely applied model organisms, and its PBS is dominantly present as a hemidiscoidal structure that contains phycocyanobilins as the only chromophores. The incident light mostly excites the pigments of the PBS rods then the excitation energy is transferred to the APC core. This PBS has six radial rods, each consists of up to three hexameric phycocyanin (PC) units attached together by $\mathrm{L}_{\mathrm{R}}{ }^{10}, \mathrm{~L}_{\mathrm{R}}{ }^{30}$ and $\mathrm{L}_{\mathrm{R}}{ }^{33}$ rod linker proteins (Fig. 2). 

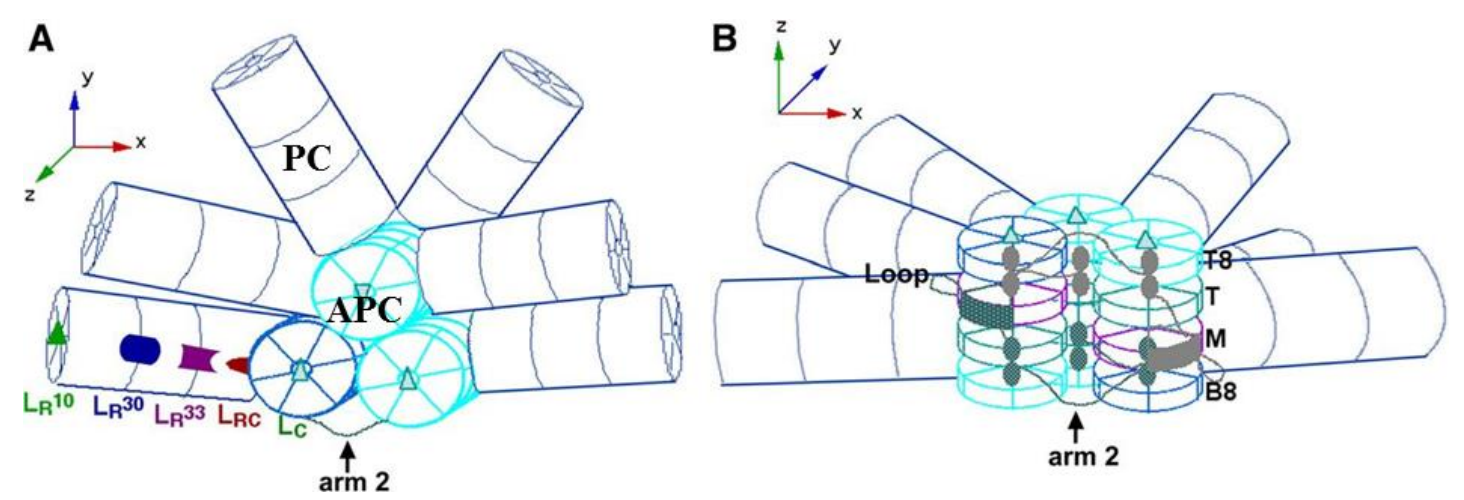

Figure 2. A model of the hemidiscoidal structure of PBS (Arteni et al 2009). Side view (A) and upward (B) view of PBS from the thylakoid membrane. Abbreviations: PC, Phycocyanin (6 rods); APC, Allophycocyanin (3 cores); $\mathrm{L}_{\mathrm{R}}{ }^{10}, \mathrm{~L}_{\mathrm{R}}{ }^{30}, \mathrm{~L}_{\mathrm{R}}{ }^{33}, \mathrm{~L}_{\mathrm{RC}}$, and $\mathrm{L}_{\mathrm{C}}$ - linker proteins; $\mathrm{T}$, T8, B8 and $\mathrm{M}$ - four subunits of APC trimers.

The central core has three cylinders, each composed of four APC trimers. Some of the APC core subunits are acting as terminal emitters (TEs) i.e. ApcD, ApcE, and ApcF which ensure the excitation energy transfer to the photosystems (Ashby \& Mullineaux 1999). As an antenna for PSI and PSII (Chang et al 2015), the PBSs absorb in the wavelength range of $500-650 \mathrm{~nm}$, which is less efficiently absorbed by the Chl $a$ molecules (380-495 and 625-740 $\mathrm{nm})$. Recently, the structure of a 16.8 MDa PBS from a red alga Griffithsia pacifica at $3.5 \AA$ resolution has been reported by using single-particle cryo-electron microscopy (Sarma et al 2016). This structure shows the important mechanisms behind the specific interactions between linkers and chromophores. It also revealed the complicated assembly and the complex mechanisms of energy transfer within the PBS and raises the question of similar processing in the PBS of the less studied species.

\subsubsection{PBS degradation process}

Beside the light harvesting function, the PBSs also function as a nutrient reservoir. Under macronutrient (e.g. nitrogen, phosphorus, and sulfur) limited conditions, the PBSs can supply amino acid residues for the cell. During macronutrient starvation, in order to release its important constituents, the PBSs go over a programmed proteolytic pathway (Schwarz \& 
Forchhammer 2005). Our present knowledge about PBS degradation was mostly obtained by using Synechococcus elongatus sp. PCC 7942 (hereafter Synechococcus) and Synechocystis strains (Schwarz \& Forchhammer 2005). The studies in these species suggested that the degradation pathway and its activation differ from species to species (Richaud et al 2001, Schwarz \& Forchhammer 2005), but the basic principles are similar.
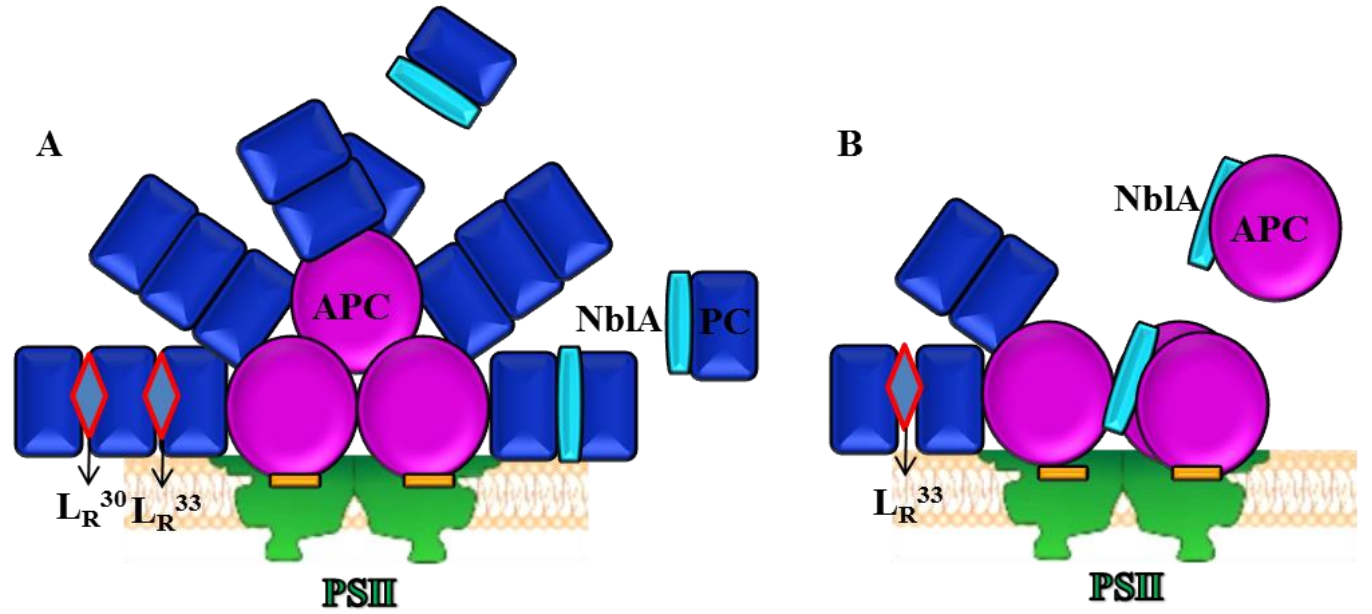

Figure 3. The simplified model of the programmed PBS degradation process. NblA protein involved in the sequential (A) rod degradation followed by (B) core degradation of PBSs.

The recent studies revealed that phosphorylational modifications of the PBS proteins are prerequisite for the directed PBS degradation (Sendersky et al 2014). The degradation is initiated by the cleavage of rod linker proteins and concomitant shortening of the rods; these events are essential for the further degradation of PBSs. Several proteins encoded by $n b l$ (non-bleaching) genes are involved in the PBS degradation (Collier \& Grossman 1994, Baier et al 2014). The NblA protein is one of the key elements involved in PBS degradation and functions as an adaptor for the PBS proteolytic enzyme (ClpC-ClpP) complex. The most recent results suggest that NblA adaptor complex interacts with the $\mathrm{N}$-terminus of $\beta$ phycocyanin (Bernát et al 2009), presents them to the ClpC-ClpP complex (Karradt et al 2008) which eventually performs the cleavage of the PBS. In contrast to the earlier hypothesis that NblA is required only for the rod degradation, recently it has been shown that 
it is also necessary for the cleavage of PBS core in Synechococcus (Fig. 3) (Sendersky et al 2015). The protein products of some of the $n b l$ genes, which participate in the PBS degradation pathway, are not only overexpressed under starvation conditions but also under high-light exposure (Kothe et al 2014). Involvement of the same proteins in the PBS degradation under starvation and high-light treatment predicts a general degradation process induced under different conditions. The alteration of the rod and core linker polypeptides are accounted for the strong light conditions (Fig. 4).

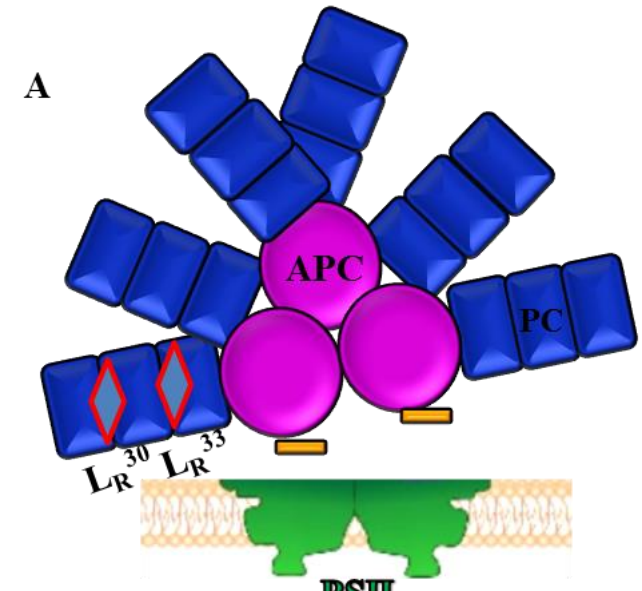

PSIII

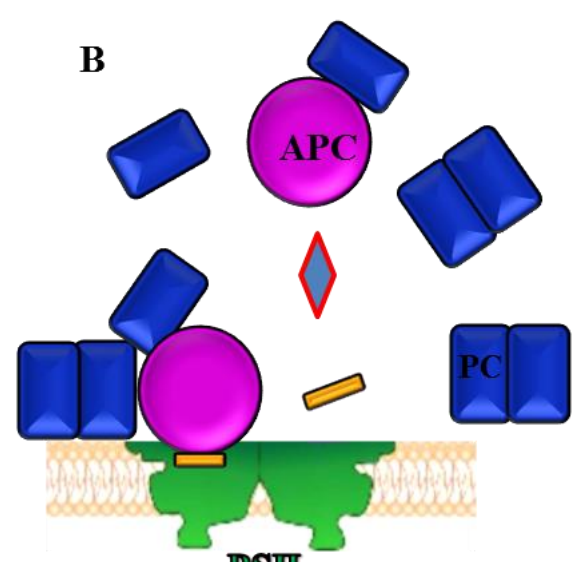

PSIII

Figure 4. The simplified model of the high light-induced effects on PBSs. (A) decoupled PBS and (B) structurally distorted PBS.

The degradation of PBSs should also occur when the cells are not exposed to stress, but probably at a lower rate. There must be a dynamic equilibrium between the assembly and degradation of PBSs which ensures the optimal level of functional PBSs (Anderson et al 2012). However, the exact mechanism and its regulation are not completely elucidated. In addition to the programmed degradation, some stress conditions such as UV-B light exposure (Six et al 2007, Zolla et al 2003), high-light treatment (Rinalducci et al 2008, Tamary et al 2012) and presence of $\mathrm{H}_{2} \mathrm{O}_{2}$ (Liu et al 2005a) can also lead to partially disassembled PBSs. Nevertheless, these structural changes are different from those observed upon programmed 
degradation and are probably due to direct damage of proteins induced by extreme stress conditions (Fig. 4).

\subsection{Cyanobacterial photosystems: structure and function}

\subsubsection{Photosystem I}

Photosystem I (PSI) is one of the major pigment-protein complexes of the oxygenic photosynthetic organisms; it is required for Fd and NADP-reduction. In PSI, the excitation energy trapping is faster than in PSII (Palsson et al 1998). The evolutionarily conserved PSI structure possesses a high sequence homology from prokaryotic cyanobacteria to higher plants. Hence, cyanobacterial PSI can be applied as a model system for investigating the mechanism of energy transfer within the PSI core complex of plants. On the other hand, while PSI complexes are present as monomers in plants, those are preferentially organized into oligomers in cyanobacteria (Kruip et al 1994, Watanabe et al 2011). Most of the wellstudied cyanobacterial species possess trimeric PSI complexes and these trimers seem to have a major physiological role at low light intensities (Fromme et al 2001) or elevated temperatures (Klodawska et al 2015). Although the exact functions of trimers have not been clarified yet, it seems that trimeric structure can improve the efficiency of the energy conversion (Karapetyan et al 1999). Until now, a high resolution (2.5 $\mathrm{A}) \mathrm{X}$-ray analysis of the complete trimeric PSI was only obtained from a thermophilic cyanobacterium, Thermosynechococcus elongatus (hereafter T. elongatus) (Jordan et al 2004). This complex is a homotrimer of multiprotein subunits where each monomer contains 127 cofactors including Chl $a, \beta$-carotene molecules and lipids (phosphatidyl-glycerol and monogalactosyldiglyceride). The monomers consist of 12 protein subunits; among those PsaA and PsaB are the biggest and most of the cofactors are bound to these proteins (Fig. 5). 


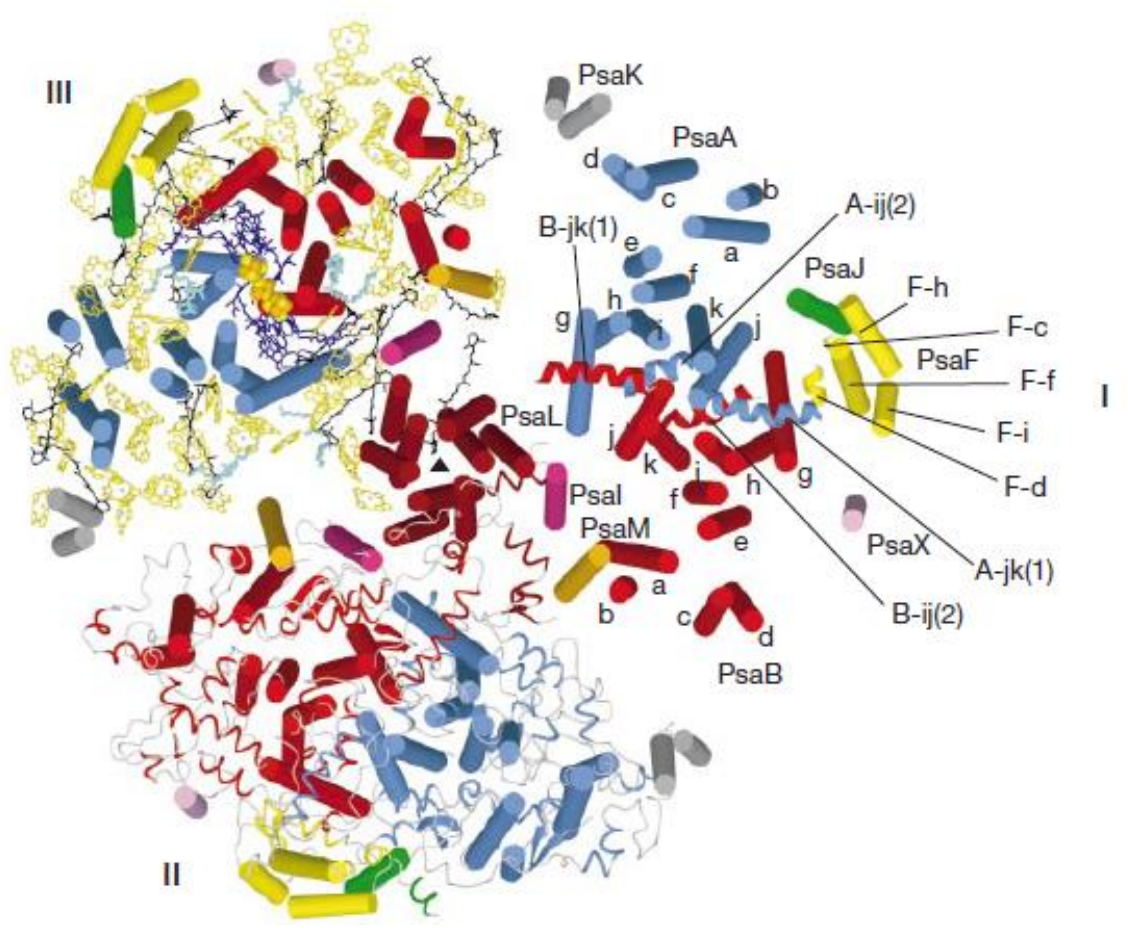

Figure 5. PSI trimeric complex of Thermosynechococcus elongatus at $2.5 \AA$ resolutions as seen from the stromal side of thylakoid membrane (Jordan et al 2001). Each monomer representation (I, II and III) shows different structural components. The arrangement of transmembrane $\alpha$-helices is shown as cylinders and different protein subunits are labeled (I). Lumenal loop regions are represented as ribbons (II). Complete set of cofactors (III): quinones and Chls (blue), iron and sulfur atoms of the three $\mathrm{Fe}_{4} \mathrm{~S}_{4}$ clusters (orange and yellow spheres, respectively); Antenna system: Chl $a$ (yellow), carotenoids (black) and lipids (turquoise).

The oligomerization of PSI is ensured by a central domain containing the PsaL protein (Chitnis \& Chitnis 1993, Klodawska et al 2015). The association of PsaL into the monomeric complex is stabilized by other subunits (i.e. PsaI and PsaM) and three $\beta$-carotene molecules (Grotjohann \& Fromme 2005, Toth et al 2015). This domain also contains the $\mathrm{Ca}^{2+}$ that is presumed to support the trimerization (Fromme et al 2001). Partial structure of PSI monomer of Synechocystis has been also obtained and revealed some structural differences between the two species (Mazor et al 2014), but further studies are needed to reveal the exact structure of trimeric PSI from Synechocystis. 
In cyanobacteria, around $90 \%$ of the total $\mathrm{Chl} a$ is bound to PSI as a consequence of the higher $\mathrm{Chl} a$ content of PSI (96 Chl $a$ /monomer) than PSII (35 Chl $a$ /monomer) (Fromme et al 2001, Gunerken et al 2015) and as high as $90 \%$ of the total Chl a molecules are associated with PSI complexes relative to PSII (Rakhimberdieva et al 2001, Tian et al 2011). Around 5-10\% of the PSI associated Chls absorb light energy at longer wavelengths; these are the so-called red-shifted or long-wavelength Chls (LWCs). The LWCs were proposed to originate from Chl-Chl interactions induced by the aggregation of Chls within the PSI complex (Fromme et al 2001, Mazor et al 2014). Generally, the number of LWCs is higher in the PSI trimers than in monomers in the studied cyanobacterial species, but their amount and spectral properties vary among species (El-Mohsnawy et al 2010, Gobets \& van Grondelle 2001). The difference in the number of LWCs in trimers and monomers were explained by the presence of Chl $a$ dimers at the trimerization domain of PSI which was also observed from T. elongatus (Jordan et al 2001) and the interaction between these two Chls is probably interrupted upon monomerization. The number of LWCs was mostly calculated based on spectroscopic data (Gobets \& van Grondelle 2001). The presence of LWCs in the Synechocystis PSI monomer structure has also been also confirmed. Synechocystis contains less LWCs than T. elongatus, but those LWCs are found in a similar orientation in the two species (Mazor et al 2014). In the present study, we also consider the amount of LWCs as an indicator for the organization of PSI complex.

In trimeric PSI complexes, a high amount of carotenoids, mostly $\beta$-carotenes were observed (Ashikawa et al 1986, Bautista et al 2005, El-Mohsnawy et al 2010). In agreement with these results, $22 \beta$-carotenes per monomer were resolved in the crystal structure of PSI from T. elongatus (Jordan et al 2001). These $\beta$-carotenes are important elements of the PSI complex influencing its structure (Toth et al 2015) and function (Bautista et al 2005). Moreover, the previous work in our laboratory demonstrated that even the xanthophyll 
deficiency (i.e. the lack of oxygenated carotene derivatives) reduces the amount of PSI oligomers in Synechocystis (Toth et al 2015).

\subsubsection{Photosystem II}

Photosystem II (PSII) is another multi-subunit protein complex of the thylakoid membranes in photosynthetic organisms. It catalyzes a unique reaction in nature - the lightinduced mechanism of water oxidation (Yagishita et al 1998). Oxygen-producing PSII pigment-protein complexes were first shown to exist primarily as dimers in a thermophilic cyanobacterium, later confirmed in plants and red algae, as well (Boekema et al 1995, Zouni et al 2005).

A high resolution structure of PSII has been obtained from T. elongatus (2.9 $\mathrm{A}$ ) (Guskov et al 2009) and Thermosynechococcus vulcanus (1.9 ^) (Umena et al 2011). These studies revealed that each monomer of PSII contains 20 protein subunits and many cofactors including $35 \mathrm{Chl} a$ molecules, $11 \beta$-carotenes, more than 20 integral lipids (monogalactosyldiacylglycerol, digalactosyl-diacylglycerol, sulfoquinovosyl-diacylglycerol and phosphatidylglycerol), 2 pheophytins, 2 plastoquinones, 2 heme irons, 1 non-heme iron, 4 manganese cluster, more than 1500 water molecules and 3 chloride ion. Each monomer of PSII possesses the antenna proteins $\mathrm{CP} 47$ and $\mathrm{CP} 43$, the main reaction center subunits D1 and D2 proteins (Fig. 6). 


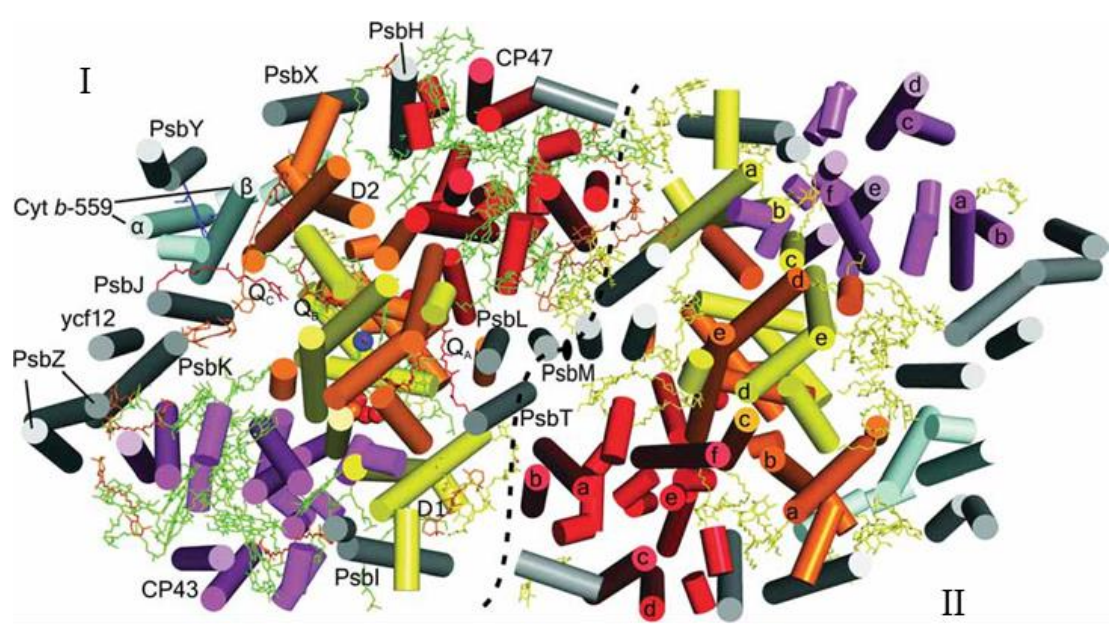

Figure 6. PSII dimeric structure of Thermosynechococcus elongatus at $2.9 \AA$ resolutions as seen from the cytoplasmic side of thylakoid membrane (Guskov et al 2009). A black dash line indicates the monomer-monomer interface. Different elements of structures have shown in each monomers (I and II). (I) Cylindrical structures are exhibiting the helical parts, D1 subunits (yellow), D2 (orange), CP43 (magenta), CP47 (red). Cofactors are shown in stick mode: Chl $a$ (green), Carotenoids (orange), heme (blue), Pheophytin (yellow), PQ (red), the $\mathrm{Mn}_{4} \mathrm{Ca}$ cluster (red and orange spheres). (II) Lipids and detergent molecules (yellow).

Chl $a$ molecules are bound to the PSII reaction center and funnel the excitation energy to the reaction center where charge separation occurs. PSII uses two types of PQ molecules $\left(\mathrm{Q}_{\mathrm{A}}\right.$ and $\left.\mathrm{Q}_{\mathrm{B}}\right)$ as mobile electron carriers to perform electron transport towards the Cyt $b_{6} f$ complex (Lamberg \& Bren 2016, Barber et al 1997). PSII is the major source for the production of harmful reactive oxygen species (ROS), especially singlet oxygen (KriegerLiszkay et al 2008) under high light stress. Singlet oxygen is highly reactive and unstable form of oxygen which has a well-known damaging effect on proteins. The D1 protein is the most sensitive to singlet oxygen but it also reacts with lipids and nucleic acids.

In cyanobacteria, the extra-membranous PBSs are attached to the PSII complex at its cytoplasmic side, whereas in plants the membrane-embedded light-harvesting antenna II is surrounded by PSII complexes (Lamberg \& Bren 2016). 


\subsection{The structure, function, and biosynthesis of carotenoids}

Carotenoids are the most widely spread pigments in nature. They are polyunsaturated hydrocarbon substances which are classified into two subgroups, the oxygen containing xanthophylls and the carotenes (oxygen free). Carotenoids are tetraterpenoids containing a long conjugated chain of double bonds which determines their light absorption (400-500 nm) properties (Sonoike et al 2001).

In photosynthetic organisms, together with tocopherol, carotenoids are the most important elements of the non-enzymatic antioxidant system (Latifi et al 2009) and also capable to quench triplet excited states of Chls (Frank \& Cogdell 1996, Domonkos et al 2013). Accordingly, in cyanobacteria the partial elimination of carotenoids decreases the stress tolerance of the cells against high-light intensities (Schafer et al 2005, Zhu et al 2010); the cells with complete carotenoid deficiency appeared to be extremely light sensitive and could be maintained only in the dark under light-activated heterotrophic growth conditions (Sozer et al 2010). Besides the protective functions, carotenoids are also important for the assembly and stabilization of photosynthetic complexes in cyanobacteria (Sozer et al 2010, Toth et al 2015), as well as in plants (Croce et al 2002, Fiore et al 2012, Dall'Osto et al 2013, Santabarbara et al 2013). The previous results in our laboratory suggested that complete carotenoid deficiency also influence the PBS structure and evokes the presence of unconnected PC rods and PBSs with shorter rods (Toth et al 2015). Although an indirect effect of carotenoids on PBS structure is more likely, further studies are needed to investigate the correlation between the carotenoid composition and the PBS organization.

Due to their physicochemical properties, the carotenoids are preferentially embedded into lipid bilayers or integrated into pigment-protein complexes (Domonkos et al 2013). In cyanobacteria, most of the $\beta$-carotene is bound to the PSs (Jordan et al 2001, Gunerken et al 
2015) and to some less abundant proteins like high-light inducible proteins (HLIPs) (Komenda \& Sobotka 2016). Besides the protein location (Daddy et al 2015, Melnicki et al 2016), a substantial fraction of non-protein-bound xanthophylls are supposed to be present in membranes (Dall'Osto et al 2013) where they can influence the molecular dynamics and microviscosity of the membranes (Gruszecki \& Strzalka 2005). Xanthophylls are often copurified with isolated PSI trimers but not considered as part of the complex ( Coufal et al 1989, Bautista et al 2005, Daddy et al 2015, Klodawska et al 2015) which predicts the presence of xanthophylls within the thylakoid membrane at the vicinity of PSI. A wide range of xanthophylls is present in various cyanobacterial species, depending on their natural habitat and taxonomical position (Takaichi \& Mochimaru 2007). In Synechocystis, the most abundant xanthophylls are zeaxanthin, echinenone, and myxoxanthophyll. In spite of the high amount of xanthophylls in the thylakoid membrane of Synechocystis, their exact localization and structural roles in the photosynthetic complexes and the thylakoid organization have not been completely unfolded yet. Several Synechocystis mutants have been generated by the inactivation of various genes, which are involved in the carotenoid biosynthesis pathways (Fig. 7).

In Synechocystis, the first step of carotenoid biosynthesis is the condensation of two molecules of geranylgeranyl diphosphate into phytoene, catalyzed by the phytoene synthase enzyme $(\mathrm{CrtB})$. The carotenoid synthesis includes subsequent isomerization steps which can be catalyzed by the carotene isomerase $(\mathrm{CrtH})$ enzyme or occur via non-enzymatic photoisomerization. Previous results showed that the non-enzymatic isomerization process obtained by photo-isomerization without $\mathrm{CrtH}$ enzyme activity results in largely decreased carotenoid content (Masamoto et al 2004, Toth et al 2015). 


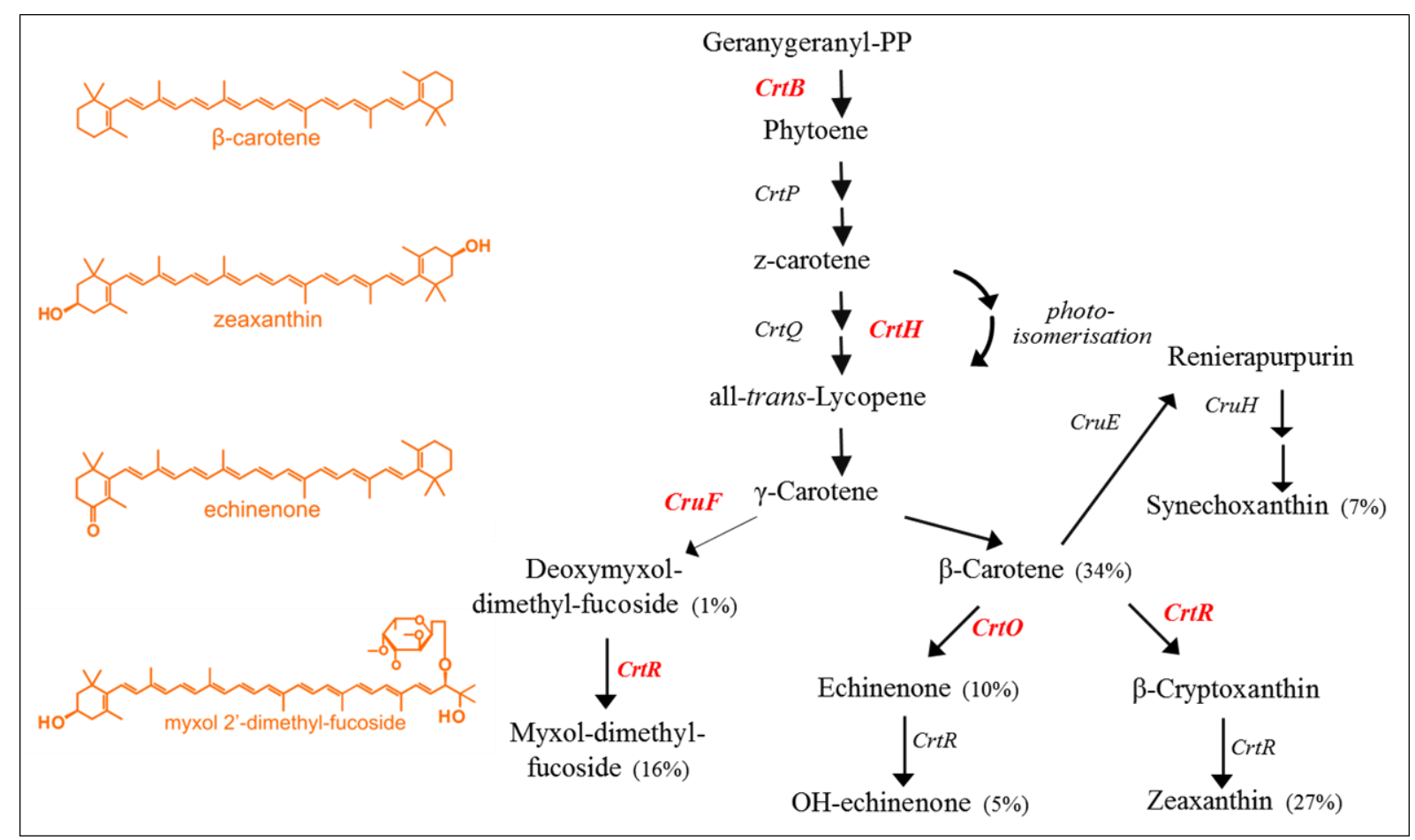

Figure 7. The chemical structure of four carotenoid molecules (A) (Domonkos et al 2013) and the major carotenoid biosynthesis pathways in Synechocystis (B). Abbreviations: CrtB, phytoene synthase; $\mathrm{CrtH}$, cis-trans carotene isomerase; $\mathrm{CrtR}$, carotene $\beta$-hydroxylase; $\mathrm{CrtO}$, carotene $\beta$-ketolase; CruF, $\gamma$-carotene 1'-hydroxylase.

Despite the low carotenoid level, crtH mutant cells are capable of growing under photoautotrophic conditions (Toth et al 2015) and maintain wild-type like growth rate and PSII activity (Masamoto et al 2004). In the following steps of the carotenoid biosynthesis, $\gamma$ carotene is produced, which supplies the myxoxanthophyll and $\beta$-carotene synthesis in parallel pathways.

Among accumulated carotenoids, $\beta$-carotene is also a key intermediate product for the synthesis of hydroxylated zeaxanthin and ketolated echinenone derivatives (Domonkos et al 2013). Zeaxanthin is synthesized from $\beta$-carotene by the $\beta$-carotene hydroxylase (CrtR) by sequentially adding hydroxyl groups at both ends of the molecule, whereas echinenone is produced by $\beta$-carotene ketolase $(\mathrm{CrtO})$, which introduces keto group at one end of $\beta$ carotene (Masamoto et al 1998). The inactivation of both the $c r t R$ and $c r t O$ genes resulted in the almost completely xanthophyll-deficient mutant, crtRO (Schafer et al 2005). Because the 
CrtR enzyme is also involved in the myxoxanthophyll biosynthesis (Lagarde \& Vermaas 1999), the $c r t R O$ and $c r t R$ mutants accumulate myxoxanthophyll intermediate (deoxymyxolfucoside) at a low level. In Synechococcus, the CruF (C-1'-hydroxylase) enzyme is essential for the synthesis of myxoxanthophyll (Zhu et al 2010). The disruption of cruF gene resulted in the generation of a myxoxanthophyll (myxol-2' fucoside) deficient mutant without relevant alteration in the amount of other carotenoid species. Using these mutants, sequential elimination of different carotenoid forms could be obtained, which allows studying their specific roles. 


\section{AIMS}

The present study was aimed at further investigating the influence of carotenoid composition on the structure and organization of the major photosynthetic complexes. In the proposed thesis, cyanobacterium Synechocystis sp. PCC 6803 was used as a photosynthetic model organism. The main advantages of using this species are its entirely sequenced genome and easy transformability. Carotenoids are the most abundant pigments in nature. They are known to be important for photoprotection, regulation of the membrane properties, but less information is available about their structural roles in the photosynthetic complexes. The photosynthetic complexes should be organized and structurally interacted in the thylakoid membrane to perform the efficient photosynthetic energy transfer.

The previous studies in our laboratory revealed that the absence or low level of carotenoids lead to the co-existence of unconnected rod units and assembled PBSs with shorter peripheral rods. It is rather surprising since the presence of carotenoids in the PBS structure has not been reported. Therefore, our aim was;

1. To find out which specific carotenoid species involved and understand the mechanism that eventually leads to the presence of unconnected PBS units, when the carotenoid composition is altered.

A reduced level of PSI oligomers upon xanthophyll deficiency was also observed, although xanthophylls are not considered to be part of any photosynthetic complexes in cyanobacteria. But these predictions were not completely clarified. Hence, our aim was also;

2. To study, how xanthophylls influence the oligomerization of PSI in Synechocystis. More specifically, which xanthophyll species contribute at what extent to the organization of the PSI complex. 


\section{MATERIALS AND METHODS}

\subsection{Organisms and growth conditions}

Cyanobacterial cells were cultivated in BG11 medium supplemented with $5 \mathrm{mM}$ HEPES-NaOH (pH 7.5). Synechocystis wild type (WT), crtH (Masamoto et al 2001), psaL (Klodawska et al 2015), PSI-/PSII- (Ermakova-Gerdes et al 1995), cruF, crtH/cruF (present study) $\operatorname{crtRO}, \mathrm{crtR}$ and $\mathrm{crtO}$ (generous gift from Kazumori Masamoto) mutant strains were grown under photoautotrophic growth (PAG) conditions. The $\operatorname{crtB}$ mutant (Toth et al 2015) and its corresponding WT cells were cultivated under light-activated heterotrophic growth (LAHG) conditions on a rotary shaker $(100 \mathrm{rpm})$ at $30{ }^{\circ} \mathrm{C}$.

Under PAG conditions, the cells were illuminated with continuous white light using $35 \mu \mathrm{mol}$ photons $\mathrm{m}^{-2} \mathrm{~s}^{-1}$ PPFD (Photosynthetic Photon Flux Density). For photomixotrophic growth (PMG) conditions, the media was supplemented with $10 \mathrm{mM}$ glucose. Under LAHG conditions, BG11 was supplemented with $10 \mathrm{mM}$ glucose and daily light pulses of $20 \mu \mathrm{mol}$ photons $\mathrm{m}^{-2} \mathrm{~s}^{-1}$ PPFD were provided for $10 \mathrm{~min}$. For oxygen polarography, the cultures were grown under $40 \mu \mathrm{mol}$ photons $\mathrm{m}^{-2} \mathrm{~s}^{-1} \mathrm{PPFD}$ of continuous white light at $3 \% \mathrm{CO}_{2}$-enriched atmosphere. High-light treatment was induced by $600 \mu \mathrm{mol}$ photons $\mathrm{m}^{-2} \mathrm{~s}^{-1}$ for WT, and $\mathrm{crtH}$ and $35 \mu \mathrm{mol}$ photons $\mathrm{m}^{-2} \mathrm{~s}^{-1}$ PPFD for $c r t B$ cells, respectively. Mutant cells were maintained in the presence of the appropriate antibiotics, $20 \mu \mathrm{g} \mathrm{ml}^{-1}$ of kanamycin for $\mathrm{crtH}$ and $\mathrm{crtR}$, spectinomycin for $c r t O, c r u F$, and $c r t B$ strains, respectively. For the double mutant $\operatorname{crtRO}$ and $c r t H / c r u F$ cells, $20 \mu \mathrm{g} \mathrm{ml} \mathrm{m}^{-1}$ kanamycin and spectinomycin were added. For the experiments, the cells were cultivated without antibiotics and used in their logarithmic growth phases. 


\subsection{Construction of Synechocystis PCC 6803 mutants}

The cosmid clone cs0508 provided by S. Tabata, was cut with the restriction enzyme HindIII. A $3.6 \mathrm{~kb}$ fragment containing the putative $c r u F$ gene (sll0814) was cloned between the SmaI and EcoRV sites of pMPMA3 (Mayer 1995) A part of the putative cruF gene coding region was removed by $S m a \mathrm{I}-E c o R I$ digestion and replaced with a $\Omega$ cassette (Sozer et al 2010). This construct was used to transform into WT and crtH mutant cells of Synechocystis. Transformants were selected under photomixotrophic growth conditions on BG11 agar plates supplemented with glucose and gradually increasing amounts of spectinomycin by several restreaking of single colonies. Complete segregation was confirmed by PCR using the primers cruF forward (5'-TTAGCGGCACCTACTTTG-3') and cruF reverse (5'-TCTGCGTTGAGTTGAGTC-3') and by pigment analysis using HPLC.

\subsection{Measurement of cell density and chlorophyll concentration}

Measurements of cell density and Chl concentration were performed by a Shimadzu UV-1601 spectrophotometer. The cell density of the cultures was determined by measuring optical density at $750 \mathrm{~nm}\left(\mathrm{OD}_{750}\right)$. For measuring absorption spectra of the cells, $\mathrm{OD}_{750}$ was adjusted; non-transparent sides of cuvettes were positioned toward the detector to decrease the effect of light scattering. Spectra were corrected to the light scattering measured at 750 $\mathrm{nm}$. For calculation of phycobilin $(630 \mathrm{~nm})$ to $\mathrm{Chl}(683 \mathrm{~nm})$ peak ratio, the amplitudes were estimated by the use of reference wavelength at 750 and $550 \mathrm{~nm}$, respectively. The Chl concentration was calculated from absorbance at $665 \mathrm{~nm}$, using 90\% methanol extract (Meeks \& Castenholz 1971). 


\section{4. $77 \mathrm{~K}$ fluorescence emission spectroscopy}

Low-temperature fluorescence emission spectra $(615-800 \mathrm{~nm})$ were measured using spectrofluorometer (Fluorolog-3/Jobin-Yvon-Spex Instrument S.A., Inc.) equipped with a liquid nitrogen cryostat. Prior to the measurements, cells containing $2 \mu \mathrm{g}$ of Chls were filtered onto the surface of a Whatman GF/C glass microfiber filter disc (25 mm diameter), dark adapted for $5 \mathrm{~min}$ and frozen in liquid nitrogen. Due to the low Chl concentration in case of $c r t B$ and PSI-/PSII- mutant strains, $1 \mathrm{ml}$ of cell suspensions adjusted to $0.35 \mathrm{OD}_{750}$ were filtered. Fluorescence was excited at 590 and $436 \mathrm{~nm}$ from the same sample without changing its orientation. The emission spectra excited at 590 and $436 \mathrm{~nm}$ were corrected for photomultiplier sensitivity and normalized to the fluorescence intensity at $720 \mathrm{~nm}$ obtained upon $436 \mathrm{~nm}$ excitation, otherwise as it is indicated in figure legends. For investigating the contribution from LWCs of PSI complexes, $2 \mathrm{~nm}$ emission slit combined with $4 \mathrm{~s}$ integration time was applied. For each spectrum, three biological samples were averaged.

\subsection{Circular-dichroism spectroscopy}

CD spectra were recorded with a JASCO J-815 dichrograph. Measurements were carried out at room temperature using $3 \mathrm{~nm}$ band-pass and $1 \mathrm{~nm}$ step size. The Chl concentration of the cell, thylakoid or PSI complex suspensions were adjusted to $10 \mu \mathrm{g} \mathrm{ml}^{-1}$ and measured in a cuvette with $1 \mathrm{~cm}$ optical path length (Klodawska et al 2015). For obtaining CD spectra after CN-PAGE, the PSI-containing bands were excised and placed between glasses and the uncovered part of the glass was masked. The recorded CD spectra were baseline-corrected using the corresponding buffers or transparent gel slices and then normalized to the $680 \mathrm{~nm}$ Chl absorption band. For each spectrum, three biological replicates were measured. To determine the amplitude of the $515 \mathrm{~nm}$ CD band, $550 \mathrm{~nm}$ was used as a reference wavelength. 


\subsection{Time-resolved fluorescence spectroscopy}

Time-correlated single-photon counting was performed according to (Reguera et al 2007) using a FluoTime 200 spectrometer (PicoQuant, Germany) equipped with a microchannel plate detector (Hamamatsu, Japan) and a PicoHarp 300 TCSPC system (PicoQuant). Room- temperature fluorescence decays were recorded with picoseconds resolution from cells in vivo at wavelengths between 620 and $720 \mathrm{~nm}$ with excitation pulses at $580 \mathrm{~nm}, 0.1 \mathrm{pJ}$ pulse energy and $20 \mathrm{MHz}$ repetition rate, generated by a WhiteLase supercontinuum laser (NKT Photonics, UK). The fluorescence decays were analyzed by global lifetime fitting (Friebe et al 2017).

\subsection{Photosynthetic oxygen polarography}

Photosynthetic oxygen-evolving activity in intact cells of WT and $c r t H$ mutant strains was measured with a Clark type oxygen electrode (Hansatech DW2). In order to provide efficient histidine (His) uptake by the cells, those were grown under $3 \% \mathrm{CO}_{2}$-enriched atmosphere at $40 \mu \mathrm{mol}$ photons $\mathrm{m}^{-2} \mathrm{~s}^{-1}$ PPFD of white light intensity for oxygen evolution experiments. Prior to the measurements, the Chl concentration of the cells was adjusted to 5 $\mu \mathrm{g} \mathrm{ml}^{-1}$ by centrifugation at $6000 \mathrm{~g}$ for $5 \mathrm{~min}$ and kept it on the shaker for at least $1 \mathrm{~h}$. In each measurement, $2 \mathrm{ml}$ of cells were used and three replicates were measured. The oxygenevolving activity of intact cells was measured in the presence or absence of $5 \mathrm{mM}$ histidine (His) using $2300 \mu \mathrm{mol}$ photons $\mathrm{m}^{-2} \mathrm{~s}^{-1}$ PPFD of white light. Singlet oxygen production was calculated as described earlier (Rehman et al 2013). PSII activity was measured in the presence of PSII electron acceptor, 0.5 mM 2,6-dimethylbenzoquinone (DMBQ), and for the photoinhibition experiments of PSII activity, $0.25 \mathrm{mM}$ lincomycin were added prior to the illumination. 


\subsection{Isolation of thylakoid membranes and cytosolic fraction}

Thylakoids were isolated by breaking the freshly collected cells in medium A $(25 \mathrm{mM}$ MES/NaOH buffer (pH 6.5), $10 \mathrm{mM} \mathrm{CaCl}_{2}, 10 \mathrm{mM} \mathrm{MgCl}_{2}$ ) containing $25 \%$ glycerol, 0.5 $\mathrm{mM}$ phenyl-methanesulfonyl fluoride (PMSF) and $1 \mathrm{mM}$ benzamidine by Bead Breaker at 5 times for 1 min using glass beads. The soluble fractions of WT LAHG and crtB LAHG cells were pelleted out by $3000 \mathrm{~g}$ at $4{ }^{\circ} \mathrm{C}$ for $5 \mathrm{~min}$. And for other cells (WT, $\operatorname{crtRO}, \operatorname{crtR}, \mathrm{crtO}$, cruF and psaL), the thylakoid membranes were collected at $35,000 \mathrm{~g}$ at $4{ }^{\circ} \mathrm{C}$ for $30 \mathrm{~min}$.

The collected thylakoid membranes were solubilized with 1 or $2 \%$ n-Dodecyl $\beta$-Dmaltoside $(\beta-\mathrm{DM})$ as it is indicated in the figure legends. Prior to the solubilization, the thylakoid membranes were washed and resuspended in the medium containing $25 \mathrm{mM}$ MES/NaOH buffer ( $\mathrm{pH} 6.5$ ), $25 \mathrm{mM}$ EDTA (ethylenediaminetetraacetic acid) and 25\% glycerol when it is indicated.

\subsection{Sucrose density gradient separation of pigment-protein complexes}

\subsubsection{Isolation of phycobilisome}

Phycobilisomes were isolated from Synechocystis of WT LAHG and crtB LAHG cells according to (Toth et al 2015). The cells were pre-treated with $0.2 \%$ lysozyme at $37{ }^{\circ} \mathrm{C}$. The cells were broken by an equal volume of glass beads $(100 \mu \mathrm{m})$ in $0.75 \mathrm{M}$ K-Na phosphate buffer ( $\mathrm{pH}$ 7.0) using Bead Breaker at 5 times for $1 \mathrm{~min}$. The thylakoid membranes were pelleted by centrifugation at 15,000 g after the treatment of Triton X-100 (5\%, w/v) at room temperature. After centrifugation, the supernatant was treated again with Triton X-100 (3\%, w/v) for $20 \mathrm{~min}$ before loading on to the discontinuous sucrose density gradient. The PBScontaining layer was collected after centrifugation at $90,000 \mathrm{~g}$ for $20 \mathrm{~h}$ at $14{ }^{\circ} \mathrm{C}$. The isolated PBS samples can be stored at room temperature for further protein and spectroscopic analysis. 


\subsubsection{Isolation of photosystem I}

Freshly isolated thylakoid membranes were washed by medium A (see section 2.9.) and solubilized with $2 \% \beta$-DM. The solubilized samples were layered on a stepwise (6 steps, $0.2-$ 0.9 M) sucrose gradient containing $20 \mathrm{mM}$ HEPES ( $\mathrm{pH} 7$ ) and $0.05 \%$ of $\beta$-DM. Centrifugation was performed at $220,000 \mathrm{~g}$ for $14 \mathrm{~h}$ at $4{ }^{\circ} \mathrm{C}$. PSI-containing fractions of the gradient were withdrawn by syringe. The collected fractions of different complexes were frozen in liquid $\mathrm{N}_{2}$ and stored at $-80{ }^{\circ} \mathrm{C}$ for further analysis.

\subsection{Protein analysis}

\subsubsection{Determination of protein concentration and SDS-PAGE}

The protein content of isolated PSI and PBSs was determined by the Bradford method (Bradford 1976). Protein composition of isolated PBSs and soluble fractions were studied using SDS-PAGE with $6 \mathrm{M}$ Urea of $15 \%$ acrylamide. The isolated PBSs were precipitated by adding an equal volume of $20 \%$ trichloroacetic acid and incubating on ice for $5 \mathrm{~min}$. The samples were denatured at $85{ }^{\circ} \mathrm{C}$ for $5 \mathrm{~min}$ in Laemmli buffer before loading. PBS samples and cytosolic fractions containing $7.5 \mu \mathrm{g}$ and $15 \mu \mathrm{g}$ of total proteins, respectively, were loaded into the wells. The separated proteins were stained with Coomassie Blue.

\subsubsection{BN- and CN-PAGE}

Thylakoid membranes were isolated (see section 2.9.). The blue-native and clear-native polyacrylamide gel electrophoresis (BN-PAGE and CN-PAGE) was performed at $4{ }^{\circ} \mathrm{C}$ in a 4-14 \% polyacrylamide gel (Lagarde \& Vermaas 1999, Komenda et al 2004). Samples were loaded onto lanes at various $\mathrm{Chl}$ content as it is indicated in the figure legend (Fig. 25). The Chl-containing protein bands were assigned based on their location in the gel (Kopecna et al 2012, Toth et al 2015). 


\subsection{Chromatographic techniques}

\subsubsection{HPLC}

Pigments were extracted from cells with an acetone-methanol mixture at a ratio of 7:2 and for the isolated PSI trimer, $80 \%$ of acetone was used. The extracted pigment solutions were passed through a $0.2 \mu \mathrm{m}$ pore size PTFE syringe filter. Samples containing equivalent amounts of Chls were separated using a $4.6 \times 250 \mathrm{~mm} \mathrm{C}_{18}$ column with $4 \mu \mathrm{m}$ particle size (Synergi Hydro-RP 80A, Phenomenex). The column was equilibrated with the solvent of acetonitrile:water:triethylamine (9:1:0.01). Pigments were eluted with one-step linear gradient from 0 to $100 \%$ ethylacetate in $25 \mathrm{~min}$ at a constant flow rate of $1 \mathrm{ml} \mathrm{min}{ }^{-1}$ (Toth et al 2015). The different pigments were identified according to their absorption spectrum and retention time. The relative content of pigments was estimated based on peak areas in the chromatograms recorded at $440 \mathrm{~nm}$ for xanthophylls (Mantoura \& Llewellyn 1983), $664 \mathrm{~nm}$ for Chl (Reguera et al 2006) and $454 \mathrm{~nm}$ for $\beta$-carotene (Hiyama et al 1969), respectively and on their corresponding extinction coefficients. The values are the mean $\pm \mathrm{SD}$ of at least three independent experiments. The synechoxanthin peak was observed only in cells but its poor resolution did not allow quantifying its amount.

\subsubsection{FPLC}

Purification of the PSI-containing fractions was achieved by using anion exchange chromatography on a Mono Q HR 5/5 column. Elution of the PSI complexes from the column was done with a linear gradient of $\mathrm{MgSO}_{4}$ (from 5 to $200 \mathrm{mM}$ ) in medium $\mathrm{B}$ (20 mM MES/NaOH buffer (pH 6.5), $10 \mathrm{mM} \mathrm{CaCl}_{2}, 10 \mathrm{mM} \mathrm{MgCl} 2,500 \mathrm{mM}$ mannitol, $0.03 \%$-DM and $0.02 \%$ sodium azide) at a flow rate of $0.4 \mathrm{ml} \mathrm{min}^{-1}$ (Fromme \& Witt 1998). The eluted fractions containing PSI trimers and monomers were pooled. The samples were concentrated 
(Millipore, Amicon ultra, $2 \mathrm{ml}, 100 \mathrm{~K}$ ) and washed by medium A containing $0.03 \% \beta$-DM. The isolated complexes were frozen in liquid $\mathrm{N}_{2}$ and stored at $-80{ }^{\circ} \mathrm{C}$ for further analysis.

\subsection{Statistical analysis}

Statistical analysis was performed using one-tailed Student's t-test in OriginPro 9.0 (OriginLab, OriginPro Software, USA). Differences were considered statistically significant with a $\mathrm{P}$-value less than 0.05 (set at $* \mathrm{P}<0.05$, $* * \mathrm{P}<0.01)$. Each value represents the mean $( \pm$ SD) of at least three independent repetitions. 


\section{RESULTS AND DISCUSSIONS}

\section{1. $\beta$-carotene influences the phycobilisome structure}

\subsubsection{Fluorescence emission of cells with modified carotenoid composition or lack of photosystems}

First of all, we have investigated the correlation between carotenoids composition and the structure of PBS antennae. In order to broaden the spectrum of light available for photosynthesis, the various elements of PBS have distinct spectral properties. Based on the spectral inhomogeneity, fluorescence spectroscopy can provide information about the energy transfer between and within the photosynthetic complexes. For instance, recording the fluorescence emission at $77 \mathrm{~K}$ (liquid nitrogen temperature) allows to separate the fluorescence emission from different complexes. This way, the emission spectra obtained upon PBS excitation refer to the energy transfer within the PBS and also from PBS to photosystems. Upon excitation, the phycocyanin (PC) rods emit fluorescence at $640-650 \mathrm{~nm}$, the allophycocyanin (APC) core at around $660 \mathrm{~nm}$, and the terminal emitter (TE) of APC has maximal fluorescence at $680 \mathrm{~nm}$.

Intensities of the fluorescence signal obtained upon PBS excitation $(590 \mathrm{~nm})$ and normalized to the PSI peak of emission spectra recorded upon Chl excitation (436 nm) contains important information about the efficiency of EET. As a first step, we identified the specific carotenoid class accountable for the previously observed unconnected PC units (Toth et al 2015). Table 1 shows the pigment composition of the various mutants used in this study. $77 \mathrm{~K}$ fluorescence emissions of carotenoid biosynthesis mutants (Table 1) such as crtRO mutant which is deficient in xanthophylls (zeaxanthin and echinenone), cruF mutant, which is deficient in myxoxanthophyll, $c r t B$ mutant does not contain any carotenoids and the less carotenoids containing $\mathrm{crtH}$ mutant were monitored and compared (Fig. 8A). 
Table 1. Distribution of the main carotenoid species in WT and partially carotenoid depleted cells. Values are given as number of pigment molecules relative to $100 \mathrm{Chl}$ molecules. Each value represents the mean of at least three independent repetitions. *The result is significant at $\mathrm{P}>0.05$ as compared to WT.

\begin{tabular}{|c|c|c|c|c|c|c|c|}
\hline $\begin{array}{c}\text { carotenoid } \\
\text { species }\end{array}$ & WT & crtRO & cruF & crtH & $\begin{array}{c}P S I^{-} \\
/ P S I I^{-}\end{array}$ & $\begin{array}{l}\text { crtH } \\
\text { PMG }\end{array}$ & $\begin{array}{l}\text { crtH/ } \\
\text { cruF }\end{array}$ \\
\hline $\begin{array}{c}\text { Myxo- } \\
\text { xanthophyll }\end{array}$ & $\begin{array}{c}6.9 \\
\pm 3.1 \\
\end{array}$ & - & - & $\begin{array}{c}7.0 \\
\pm 2.0 \\
\end{array}$ & $\begin{array}{c}57.4 \\
\pm 1.4^{*} \\
\end{array}$ & $\begin{array}{c}4.6 \\
\pm 2.9 \\
\end{array}$ & - \\
\hline Zeaxanthin & $\begin{array}{c}9.5 \\
\pm 1.2\end{array}$ & - & $\begin{array}{c}16.7 \\
\pm 0.8\end{array}$ & $\begin{array}{c}3.3 \\
\pm 0.3^{*}\end{array}$ & $\begin{array}{l}120.3 \\
\pm 0.5^{*}\end{array}$ & $\begin{array}{c}3.1 \\
\pm 0.4 *\end{array}$ & $\begin{array}{c}4.7 \\
\pm 0.3^{*}\end{array}$ \\
\hline Echinenone & $\begin{array}{c}6.4 \\
\pm 1.3 \\
\end{array}$ & - & $\begin{array}{c}8.1 \\
\pm 0.8\end{array}$ & $\begin{array}{c}1.9 \\
\pm 0.7 *\end{array}$ & $\begin{array}{r}18.6 \\
\pm 1.7 *\end{array}$ & $\begin{array}{c}1.6 \\
\pm 1.4 *\end{array}$ & $\begin{array}{c}3.1 \\
\pm 0.4 *\end{array}$ \\
\hline$\beta$-carotene & $\begin{array}{r}15.6 \\
\pm 2.7\end{array}$ & $\begin{array}{r}18.3 \\
\pm 2.3\end{array}$ & $\begin{array}{r}17.8 \\
\pm 1.8\end{array}$ & $\begin{array}{c}8.8 \\
\pm 0.5^{*}\end{array}$ & $\begin{array}{c}23.0 \\
\pm 1.9 *\end{array}$ & $\begin{array}{c}8.3 \\
\pm 0.8 *\end{array}$ & $\begin{array}{c}8.1 \\
\pm 0.3^{*}\end{array}$ \\
\hline
\end{tabular}

In the almost completely xanthophyll-deficient $\operatorname{crtRO}$ mutant (Table 1) the fluorescence spectra were not significantly affected (Fig. 8A). Upon PBS excitation, the emission spectra of WT and $c r t R O$ are dominated by three major bands; the PC related 640$650 \mathrm{~nm}$ bands, the 685 and $695 \mathrm{~nm}$ ones predominantly originate from PSII, and at $720 \mathrm{~nm}$, the PSI complex has fluorescence emission. The $c r t R O$ strain contains significant amount of desoxy-myxoxanthophyll, an intermediary product of myxoxanthophyll biosynthesis (Schafer et al 2005). Since desoxy-myxoxanthophyll molecule might substitute for myxoxanthophyll with certain functions, a completely myxoxanthophyll-deficient mutant (cruF) has been generated (Table 1) and studied. Our experiments did not reveal any significant difference in the fluorescence spectra of $c r u F$ cells relative to WT, whereas, in the completely carotenoiddeficient mutant $c r t B$, the PC as well as the TE-related $680 \mathrm{~nm}$ peaks was highly increased. The increase of the PC peak indicates functionally unattached PC units which are unable to transfer their energy towards the APC core of the PBSs. The similar effect was observed earlier in time-resolved fluorescence experiments (Toth et al 2015). The high intensity fluorescence emission from the TE indicates a disturbed EET from the PBSs to photosystems due to the absence of PSII in the $c r t B$ cells (Sozer et al 2010, Toth et al 2015). The $c r t H$ cells 
containing less carotenoid, including $\beta$-carotene, in comparison with WT (Table 1) and this mutant also showed higher PC fluorescence amplitude similarly to $\mathrm{crtB}$ cells.
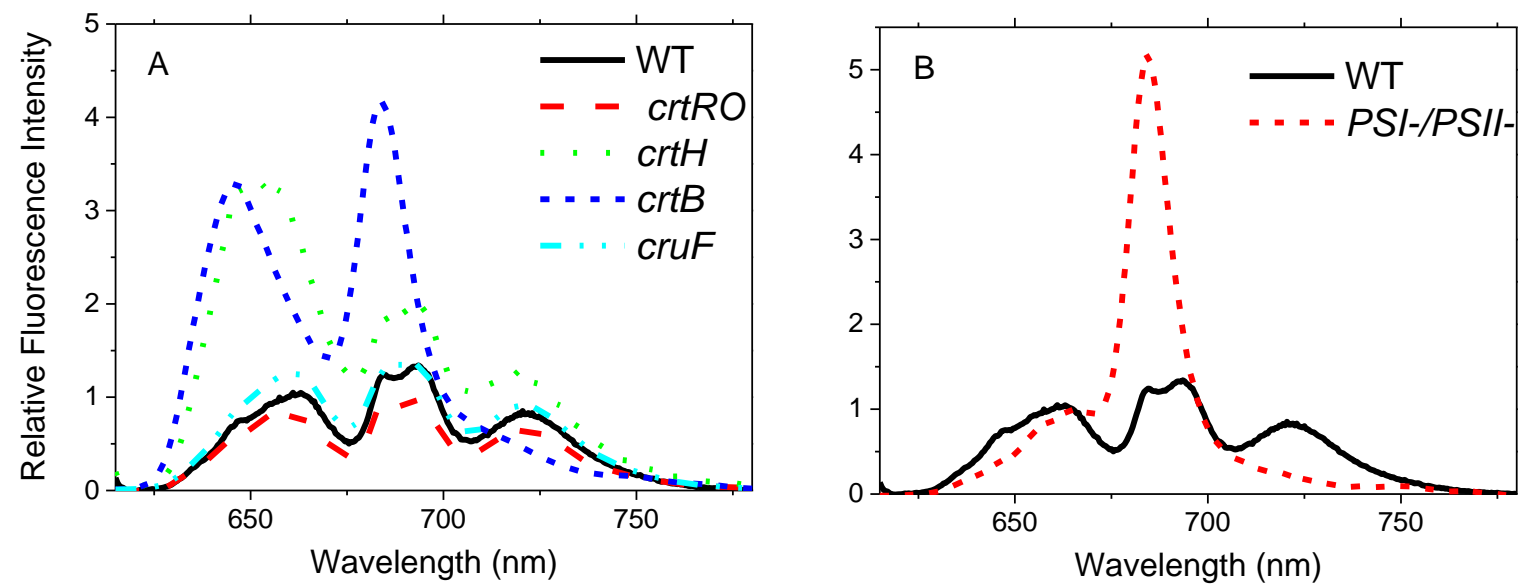

Figure 8. $77 \mathrm{~K}$ fluorescence emission spectra of Synechocystis WT, and $\operatorname{crtRO}, \operatorname{crtH}$, crtB, cruF PSI-/PSII- mutant cells. Spectra were obtained upon excitation at $590 \mathrm{~nm}$ and normalized to the amplitudes of the $720 \mathrm{~nm}$ band recorded upon $436 \mathrm{~nm}$ excitation of the same sample for WT, crtRO, $c r t H$, and $c r u F$. The fluorescence emission spectrum of $c r t B$ was normalized to the $640 \mathrm{~nm}$ amplitude of $\mathrm{crtH}$ cells upon $590 \mathrm{~nm}$ excitation and the spectrum of PSI-/PSII- mutant was normalized to the $665 \mathrm{~nm}$ band amplitude of WT.

Based on these results, we confirm that none of the xanthophylls, including myxoxanthophyll, can significantly influence the PBS structure. The previous hypothesis from our laboratory (Toth et al 2015) confirmed here. Accordingly, $\beta$-carotene is the only carotenoid that is required for assembled PBSs and the absence or decreased level of $\beta$ carotene brings about the appearance of unconnected PC units. In the completely carotenoiddeficient mutant, no active or assembled PSII complexes could be observed (Sozer et al 2010, Toth et al 2015). One might argue that in the absence of functional PSII, the PBSs could be partially degraded. In order to investigate the possible effect of photosystems on the functional assembly of PBSs, we used the PSI and PSII-deficient strain, PSI-/PSII-. The $77 \mathrm{~K}$ fluorescence emission spectrum of PSI-/PSII- mutant strain was dominated by the TE fluorescence peak, but no increase in the PC originated band was observed (Fig. 8B). Similar spectra as what is characteristic to detached PBSs were obtained from cells which are unable 
to synthesize $\mathrm{Chl}$ and consequently to accumulate photosystems (Yu et al 1999). These observations imply that the absence of photosystems in the cells cannot be held liable for the disconnected PC units.

In cyanobacteria, the majority of $\beta$-carotene molecules are present in the two photosystems (Domonkos et al 2013). Accordingly, in the PSI-/PSII- mutant, xanthophylls showed up to 10 -fold increase in their amount relative to Chl (Table 1) and the $\beta$-carotene exhibited an almost parallel decrease with Chl. These results suggest that the small fraction of non-photosystem-bound $\beta$-carotenes is necessary to avoid the presence of the unconnected PC units. Although it was proposed that all $\beta$-carotenes should be bound to proteins in cyanobacteria (Ashikawa et al 1986), this idea has not yet been proven (Domonkos et al 2013). It is noteworthy that some members of the high-light-inducible protein (HLIP) family were recently confirmed to participate in the formation of carotenoid-containing complexes (Knoppova et al 2014) (Daddy et al 2015) and known to perform mostly protective roles during high light stress. Results showed that the complex containing HliA/B binds to myxoxanthophyll and zeaxanthin (Daddy et al 2015), while the pigment-protein complex involving $\mathrm{HliC} / \mathrm{D}$ possesses $\beta$-carotene (Knoppova et al 2014). It was also demonstrated that in the absence of all five HLIP proteins, the carotenoid content was changed as compared to WT, especially the myxoxanthophyll and $\beta$-carotene level (Xu et al 2004). It is possible that these proteins indirectly influence the PBS protection or photorecovery; but, up to now, there is no indication of PBS related function of these proteins.

\subsubsection{Protein analysis of the cytosolic fraction from crtB cells}

In order to investigate the presence of rod linker proteins in the cells, we have performed the protein analysis. In the PBS complex, the $\mathrm{L}_{\mathrm{R}}{ }^{30}$ and $\mathrm{L}_{\mathrm{R}}{ }^{33}$ rod linker proteins connect the PC units to each other within the rods (Ughy \& Ajlani 2004). The previous study 
in our laboratory revealed assembled PBSs in $c r t B$ and $c r t H$ cells, but with substantially shorter PC rods. The shorter rods were reflected by the reduced level of the $\mathrm{L}_{R}{ }^{30}$ and $\mathrm{L}_{\mathrm{R}}{ }^{33}$ proteins as compared to the other linker proteins in both strains (Toth et al 2015). Cytosol of the cells contains both the assembled PBSs and disconnected PC rods. In this study, denaturing SDS-PAGE was carried out to compare the relative amount of rod linker proteins in the cytosol and in the isolated PBSs of WT and completely carotenoid deficient $\operatorname{crtB}$ cells (Fig. 9).

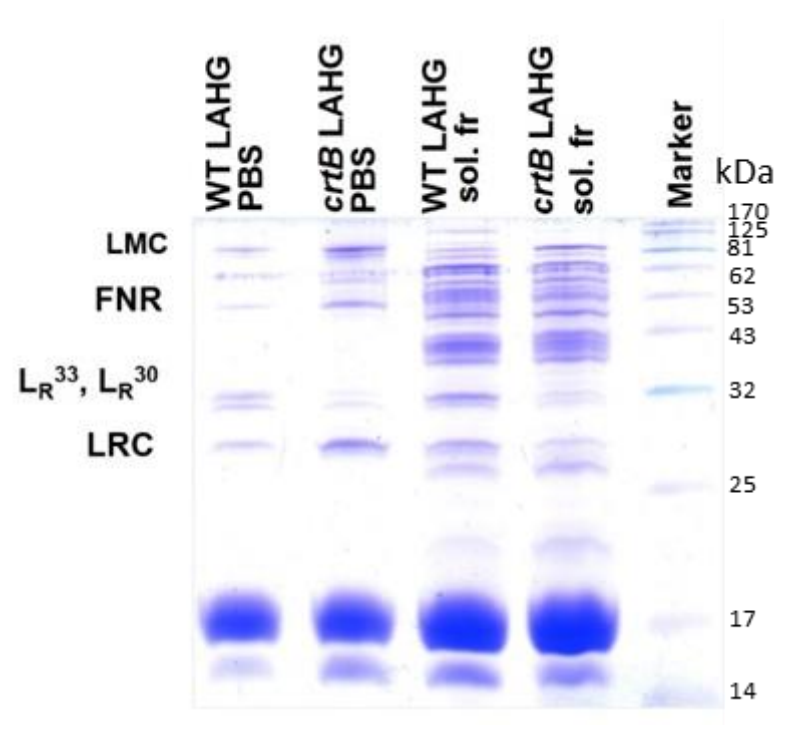

Figure 9. SDS-PAGE of the isolated PBS and cytosolic fractions of WT and $c r t B$ LAHG cells. The identities of the corresponding polypeptides such as core-membrane linker (LMC), ferredoxin/NADP ${ }^{+}$oxidoreductase (FNR), $33 \mathrm{kDa}$ rod linker proteins $\left(\mathrm{L}_{\mathrm{R}}{ }^{33}\right), 30 \mathrm{kDa}$ rod linker proteins $\left(\mathrm{L}_{\mathrm{R}}{ }^{30}\right)$ and linker rod-core $(\mathrm{LRC})$ are indicated on the left side of the gel and the molecular weight markers in $\mathrm{kDa}$ are indicated on the right side. Isolated PBS samples containing $7.5 \mu \mathrm{g}$ of protein and cytosolic fractions containing $15 \mu \mathrm{g}$ of protein were loaded.

We observed a reduced level of rod linker proteins $\left(\mathrm{L}_{\mathrm{R}}^{30}\right.$ and $\left.\mathrm{L}_{\mathrm{R}}{ }^{33}\right)$ in $\operatorname{crtB}$ strain, not only in its isolated PBS sample, but also in its cytosolic fraction. These results suggest that a higher rate of degradation or reduced synthesis of linker proteins can be accounted for the lowered amount of linkers in the absence of carotenoids. 


\subsubsection{High light-induced damage in carotenoid deficient mutants}

The completely carotenoid-deficient $(c r t B)$ strain suffers from severe effects such as extreme light sensitivity, fragmented thylakoid membranes and absence of PSII (Sozer et al 2010, Toth et al 2015). For these reasons, $c r t H$ cells grown under photoautotrophic conditions were preferentially used in the further experiments. In these cells, the photosynthetic functions were almost completely restored (Masamoto et al 2004) (Table 2), but the $\beta$ carotene dependent changes regarding the PBS structure were still noticeable. The $\mathrm{crtH}$ strain exhibited WT level of $\mathrm{CO}_{2}$ dependent $\mathrm{O}_{2}$ evolution rates (Table 2) and somewhat higher PSII activity than WT cells, similarly to the literature data (Masamoto et al 2004). These results support the presence of functional photosynthetic electron transport chain in the $\mathrm{crtH}$ mutant. Thus, using the $\mathrm{crtH}$ strain facilitates the understanding of the correlation between $\beta$-carotene and PBS structure via decreasing the complexity of the model system.

Table 2. Photosynthetic electron transport activities $\left[\mu \mathrm{mol} \mathrm{O}_{2}(\mathrm{mg} \mathrm{Chl})^{-1} \mathrm{~h}^{-1}\right]$ measured in terms of electron transport from water to $\mathrm{CO}_{2}$ in presence or absence of histidine (His) from water to DMBQ by a Clark type oxygen electrode. * The result is significant at $\mathrm{P}>0.1$ or $* *$ at $\mathrm{P}>0.05$ as compared to $\mathrm{WT}$.

\begin{tabular}{|c|c|c|c|c|}
\hline strain & $\begin{array}{c}\text { from DMBQ } \\
\text { to } \mathrm{CO}_{2}\end{array}$ & $\begin{array}{c}\text { from } \mathrm{H}_{2} \mathrm{O} \text { to } \\
\mathrm{CO}_{2}\end{array}$ & $\begin{array}{c}\mathrm{H}_{2} \mathrm{O} \text { to } \mathrm{CO}_{2} \\
\text { in presence of } \\
\text { His }\end{array}$ & $\begin{array}{c}\text { calculated } \\
\mathrm{O}_{2} \text { uptake by } \\
\text { His }\end{array}$ \\
\hline WT & $201 \pm 68$ & $141 \pm 18$ & $120 \pm 19$ & $20 \pm 3$ \\
\hline crtH & $282 \pm 59^{*}$ & $139 \pm 25$ & $103 \pm 23^{*}$ & $37 \pm 5^{* *}$ \\
\hline
\end{tabular}

In this present study, we have investigated the possibility of the reactive oxygen species (ROS) induced direct damage on the rod linker proteins. It is generally accepted that carotenoids have paramount importance in scavenging ROS (Schafer et al 2005, Latifi et al 2009, Domonkos et al 2013). In case of reduced carotenoid content, the lowered capacity to scavenge ROS can result in an increased level of these harmful agents. ROS induced damage of PBSs was previously observed (Liu et al 2005b, Rinalducci et al 2008 ), as well as the 
ROS production by the phycobiliproteins (He et al 1997) and PBSs (Rinalducci et al 2008); therefore direct damage of the PBS or the rod linkers caused by ROS is also plausible in the carotenoid deficient mutant or the cells possessing lower amount of carotenoids and subsequently, largely reduced ROS scavenging activity. Alternatively, singlet oxygen $\left({ }^{1} \mathrm{O}_{2}\right)$ may inhibit the synthesis of the linker proteins, similarly to that shown for the case of D1 protein subunit of the PSII reaction center complex (Nishiyama et al 2001, Latifi et al 2009). Neither specific degradation of PBS rod linker proteins nor inhibition of their synthesis by ${ }^{1} \mathrm{O}_{2}$ has been directly demonstrated.

We applied histidine trapping method (Rehman et al 2013) to measure the ${ }^{1} \mathrm{O}_{2}$ producing capacity of WT and $c r t H$ cells (Table 2). In our experiments, the $c r t H$ mutant showed an almost two-fold increase in the rate of ${ }^{1} \mathrm{O}_{2}$ production as represented by the calculated $\mathrm{O}_{2}$ uptake of histidine. It is generally known that upon high light stress, the ROS production especially that of ${ }^{1} \mathrm{O}_{2}$ increases (Rehman et al 2013).

PSII activity of cells with enhanced ${ }^{1} \mathrm{O}_{2}$ production should be more light sensitive (Rehman et al 2013); therefore, we followed the time-course of PSII activity under high light (600 $\mu$ mole photons $\mathrm{m}^{-2} \mathrm{~s}^{-1}$ PPFD) conditions by recording the DMBQ-dependent $\mathrm{O}_{2}$ evolution of the cells. The light treatment was performed in the presence of lincomycin, in order to exclude the possible influence of altered PSII re-synthesis. In line with our ${ }^{1} \mathrm{O}_{2}$ measurements, the $\mathrm{crtH}$ cells exhibited a more severe decrease in the PSII activity (Fig. 10). 


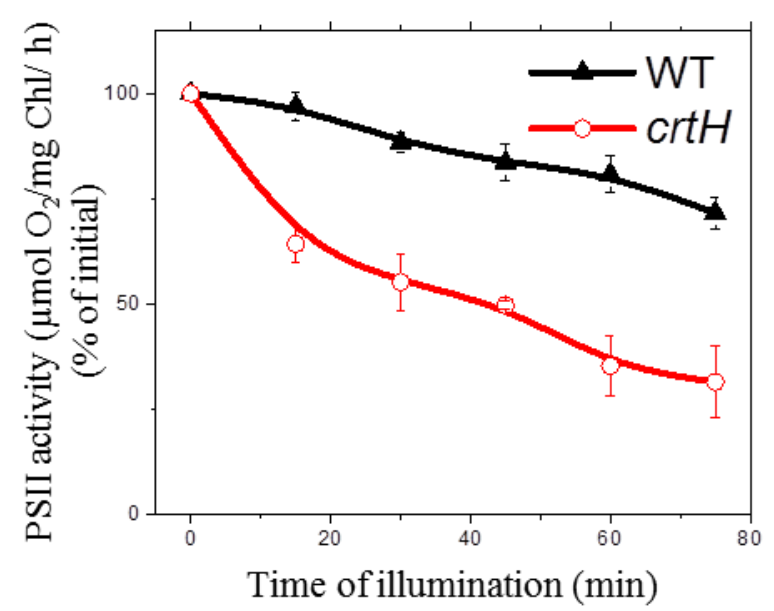

Figure 10. Effect of high light treatment on the PSII activity of WT and $c r t H$ cells. $\mathrm{O}_{2}$ evolution was recorded in the presence of artificial PSII electron acceptor (0.5 mM DMBQ) as a function of time. Cells were illuminated by $600 \mu$ mole photon $\mathrm{m}^{-2} \mathrm{~s}^{-1}$ PPFD in the presence of $0.25 \mathrm{mM}$ lincomycin. The activities corresponding to $100 \%$ for the untreated cells.

This result is in agreement with the previous findings, which showed a correlation between photodamage and enhanced ${ }^{1} \mathrm{O}_{2}$ production (Rehman et al 2013, Bersanini et al 2014), and also with the influence of carotenoid content on the rate of ${ }^{1} \mathrm{O}_{2}$ formation and the related photodamage (Hakkila et al 2014, Sedoud et al 2014). The recorded high level of ${ }^{1} \mathrm{O}_{2}$ among other ROS can cause the degradation of rod linker proteins $\left(\mathrm{L}_{\mathrm{R}}^{33}\right.$ and $\left.\mathrm{L}_{\mathrm{R}}{ }^{30}\right)$ or inhibit their synthesis and thus lead to the formation of unconnected PC units in the crtH cells. If the $\beta$-carotene limitation reduces the synthesis of rod linkers, a similar effect could be expected as in the cells deficient in these proteins (Ughy \& Ajlani 2004). The $\mathrm{L}_{\mathrm{R}}{ }^{33}$ rod linker protein attaches the second PC hexamer to the basal one and in the mutant which is unable to synthesize $\mathrm{L}_{\mathrm{R}}^{33}$ protein, the PC hexamers were accumulated only in one oligomeric form. Moreover, the $\mathrm{L}_{\mathrm{R}}{ }^{33}$ protein deficient mutant possesses one fraction of disconnected PC units with identical size as the mutants lacking $\mathrm{L}_{\mathrm{R}}{ }^{30}$ protein or both the $\mathrm{L}_{\mathrm{R}}{ }^{33}$ and $\mathrm{L}_{\mathrm{R}}{ }^{30}$ proteins (Ughy \& Ajlani 2004) suggesting a sequential assembly of PBSs in vivo despite of the high propensity for aggregation in vitro (Adir 2005). However, the previous experiments in our 
laboratory revealed two fractions of PC units in different aggregation forms in $\mathrm{crtH}$ and $\mathrm{crtB}$ cells (Toth et al 2015). We hypothesize that the presence of aggregated PC hexamers could indicate that those were previously part of assembled PBSs. Thus, the appearance of the detached PC units is more likely to occur as the results of PBS disassembly than of an improper assembly.

In order to further elucidate the relationship between ROS and PBS disassembly, we followed the time-course of changes in the fluorescence emission of $\operatorname{crtH}$ and $\mathrm{crtB}$ cells under light stress conditions (Fig. 11). In these experiments, the $c r t H$ mutant strain was illuminated with $600 \mu$ mole photons $\mathrm{m}^{-2} \mathrm{~s}^{-1}$ PPFD (Fig. 11A). This intensity is not high enough to cause PBS damage in WT (Rinalducci et al 2008), but might be sufficient to damage the PBSs of mutants possessing a lower amount of carotenoids. In the $\mathrm{crtH}$ strain, the most pronounced decreases were observed in the PSII related fluorescence emission peaks (685 and $695 \mathrm{~nm}$ ) due to the higher sensitivity of PSII complex against light stress. However, there were no significant changes in PBS peak of the cells within $3 \mathrm{~h}$. After $5 \mathrm{~h}$ treatment, the peak originating from disconnected PC was slightly decreased. Thus, $c r t H$ cells showed a higher propensity for bleaching or complete degradation of PBSs than for the accumulation of unconnected PC units. 

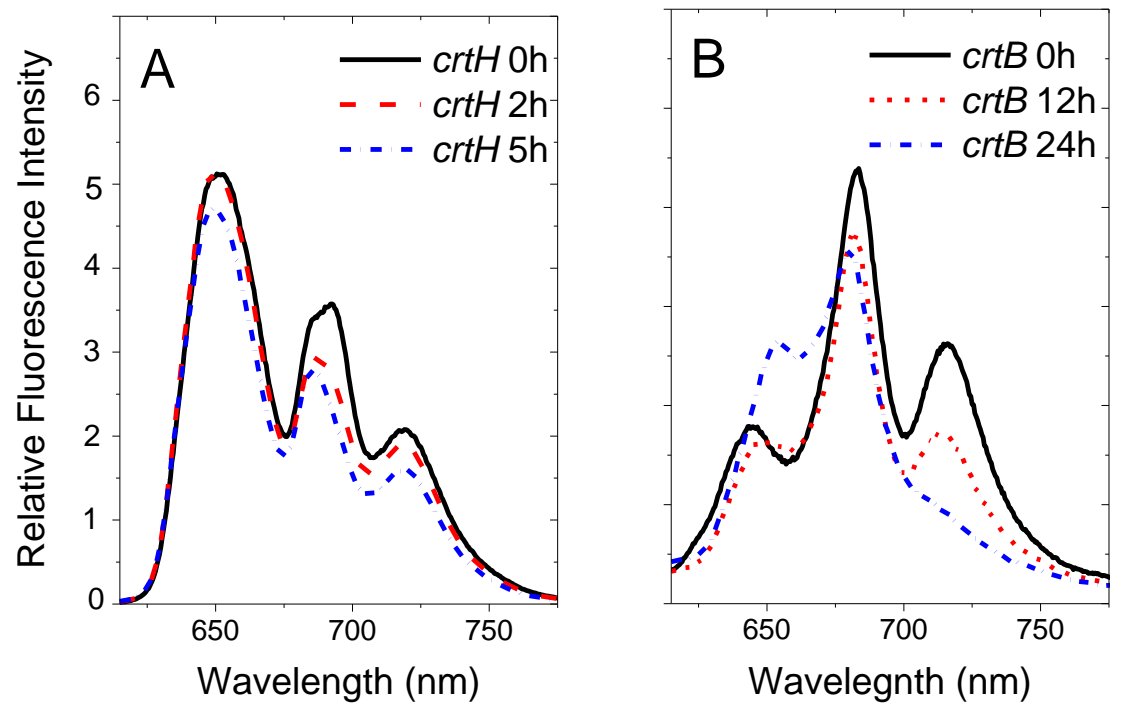

Figure 11. Photoinhibition of $c r t H$ and $c r t B$ LAHG strains were followed by recording $77 \mathrm{~K}$ fluorescence emission spectra. The light intensity during the treatment was 600 and $35 \mu$ mole photons $\mathrm{m}^{-2} \mathrm{~s}^{-1}$ for $\operatorname{crtH}(\mathrm{A})$ and $\operatorname{crtB}$ (B) cells, respectively. The spectra of $\operatorname{crtH}$ were obtained upon excitation at $590 \mathrm{~nm}$ and normalized on $720 \mathrm{~nm}$ band recorded upon $436 \mathrm{~nm}$ excitation. For crtB cells, the spectra were recorded upon $436 \mathrm{~nm}$ excitation and the measurements were performed on cells possessing the same optical density at $750 \mathrm{~nm}$.

The dark grown $c r t B$ mutant strain was also exposed to light stress (Fig. 11B), but by using low light intensity ( $35 \mu$ mole photons $\mathrm{m}^{-2} \mathrm{~s}^{-1} \mathrm{PPFD}$ ) due to its extreme light sensitivity (Sozer et al 2010). In the $\operatorname{crtB}$ mutant, the increased peak of unconnected PC units was observed only after $24 \mathrm{~h}$ when Chl bleaching (Sozer et al 2010) and most probably cell death was already occurring. It seems that light stress and consequently the increase of ROS is most likely insufficient for accelerating the damage of PBS structure more than that of photosystems in $c r t H$ and $c r t B$ mutants. Therefore, ROS are unlikely able to directly damage the rod linkers which are already integrated into PBSs. 


\subsubsection{Effect of glucose on crtH cells}

Oxidative stress to some extent is induced by the presence of glucose in the growth media (Narainsamy et al 2013) and is accompanied by a concomitant increase of carotenoid synthesis (Ryu et al 2004). Therefore, we also studied the fluorescence emission spectra of WT and crtH cells grown under photomixotrophic (PMG) conditions in glucosesupplemented media (Fig. 12A). Under PMG conditions, only slight differences were detected by the fluorescence emission spectra of WT cells. However, a higher level of disconnected PC units was observed in $c r t H$ PMG strain relative to the PSI fluorescence as reflected by the increased contribution of $640 \mathrm{~nm}$ band to the emission spectra. The absorption spectra of these cells were also recorded (Fig. 12B).
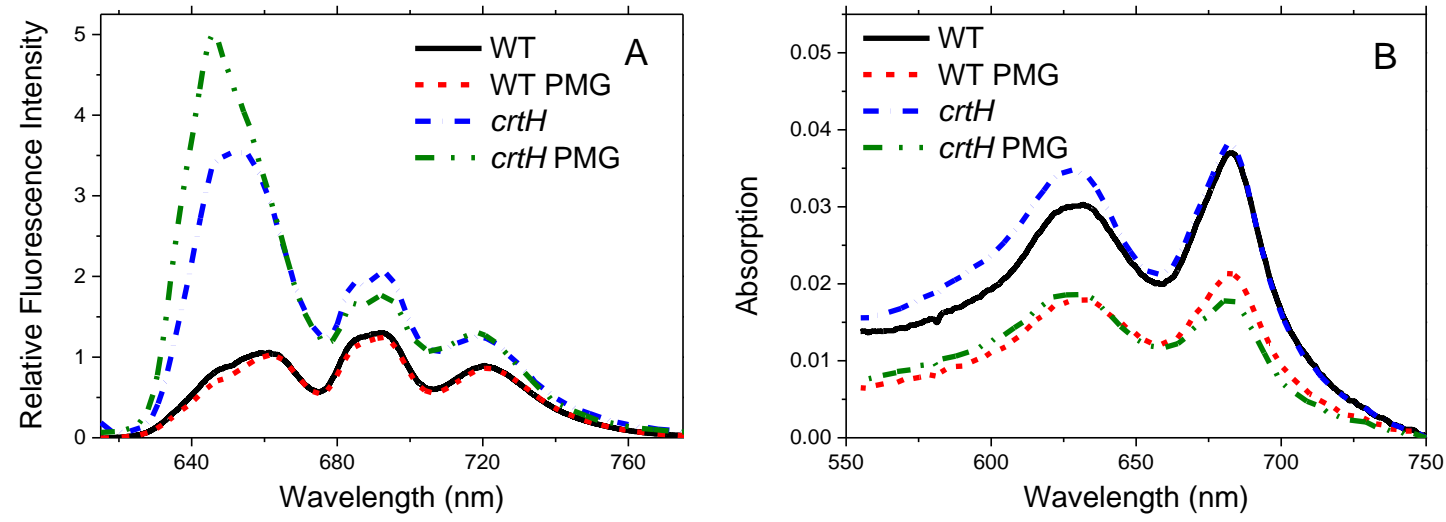

Figure 12. $77 \mathrm{~K}$ fluorescence emission (A) and absorption (B) spectra of WT and $\mathrm{crtH}$ strain grown under photoautotrophic (WT and $c r t H$ ) and photomixotrophic (WT PMG and $c r t H$ PMG) conditions. Emission spectra were obtained upon excitation at $590 \mathrm{~nm}$ and normalized to the amplitudes of $720 \mathrm{~nm}$ band recorded upon $436 \mathrm{~nm}$ excitation from the same sample. The absorption spectra were obtained from cultures with the same $\mathrm{OD}_{750}$ values and corrected for baseline.

Prior to the measurement, the cultures were adjusted to a same $\mathrm{OD}_{750}$ value that allows estimating the relative pigment content of the cells. Cultivation of the cells in the presence of glucose resulted in significantly reduced amount of pigments in both the WT and crtH cells as reflected by the substantially lower PBS and Chl peaks. The increased level of 
unconnected PC units in $c r t H$ PMG cells could be attributed to a decrease in $\beta$-carotene content when cells are cultivated in glucose-supplemented media. However, we could not establish any significant difference between the pigment composition of the $\mathrm{crtH}$ cells grown under autotrophic and PMG conditions (Table 1).

\subsubsection{Additional myxoxanthophyll deficiency in crtH cells}

Based on the pigment composition, the $c r t H$ cells possess similar myxoxanthophyll content as WT; while the amount of all other carotenoids is much lower (Table 1). Myxoxanthophyll is a very efficient scavenger of ROS (Domonkos et al 2013) and a high level of this carotenoid may indicate an increased demand for the protection against ROSmediated damage. Hence, in this present study, we generated a double mutant in which both the CrtH and CruF enzyme functions are missing (Table 1). If ROS influenced PBS distortion (Liu et al 2005a, Rinalducci et al 2008) in $\mathrm{crtH}$ cells, somewhat higher level of the disconnected PC units would be expected in the double mutant $c r t H / c r u F$ cells; but in our 77 K fluorescence measurements, no significant increase of the emission peak originating from PC was observed (Fig. 13).

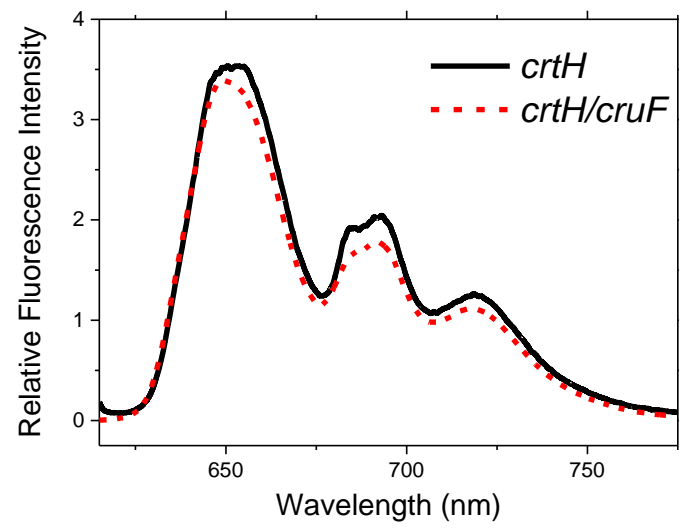

Figure 13. $77 \mathrm{~K}$ fluorescence emission spectra of $\mathrm{crtH}$ and $\mathrm{crtH} / \mathrm{cruF}$ strains obtained upon $590 \mathrm{~nm}$ excitation. The spectra normalized on $720 \mathrm{~nm}$ bands recorded upon $436 \mathrm{~nm}$ excitation. 
In fact, neither photoinhibition nor absence of myxoxanthophyll could enhance the level of unconnected PC units in $c r t H$ strain. These results support the ideas that ROS are not directly involved in the distortion of PBSs upon limited $\beta$-carotene availability and also that the increased amount of unconnected PC units in the presence of glucose is probably induced by a mechanism not related to ROS.

\subsubsection{Nitrogen shortage induced PBS degradation in crtH and crtB strains}

Our knowledge about enzymatic phycobilisome degradation has been primarily obtained by performing macronutrient-starvation experiments on various cyanobacterial strains (Schwarz \& Forchhammer 2005). Here, we used nitrogen-deficiency to trigger an enhanced PBS degradation in WT, $c r t H$, and $c r t B$ cells. In nitrogen-depleted media, the amount of the pigment-protein complexes especially that of PBSs were largely reduced within a short time as represented by the color change of the cell cultures (Fig. 14) in agreement with earlier published data in the literature. During the process of nitrogen starvation-induced proteolysis, the cyanobacterial cells were changing their color from bluegreen to yellow-green (Fig. 14); this process is known as bleaching or chlorosis (Blankenship \& Chen 2013). In our experiments, the $c r t H$ mutant showed greenish color even at the later stage of nitrogen starvation. The observed effect could be explained by the lower level of the yellow color carotenoids in $\mathrm{crtH}$ cells relative to the bluish PBS or by the delayed degradation of phycobiliproteins under $\beta$-carotene limited conditions as compared to the WT (Fig. 14).

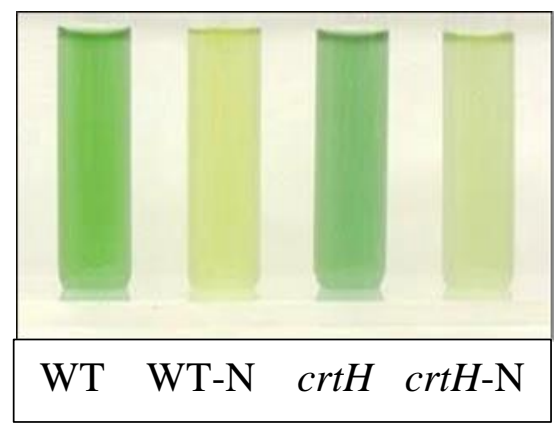


Figure 14. Effect of nitrogen starvation on the Synechocystis WT and crtH mutant cells. Cells were incubated in nitrogen-free media for $48 \mathrm{~h}$.

The absorption spectra of WT cells showed a stronger decrease in the PBS peak relative to the $\mathrm{Chl}$ peak after $24 \mathrm{~h}$ (from the ratio of 0.69 to 0.48 ) and this difference was more pronounced after $48 \mathrm{~h}$ (Fig. 15) (to 0.17) treatment.

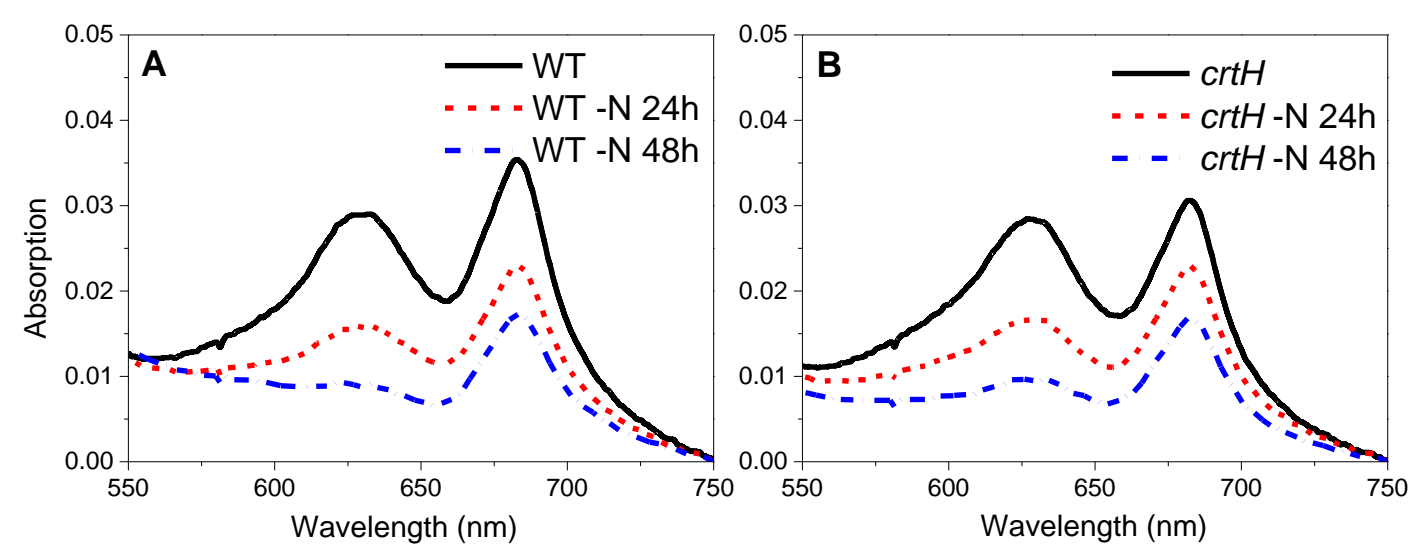

Figure 15. Effect of nitrogen starvation on the absorption spectra of WT and $c r t H$ strains. Cells were cultivated in nitrogen-free media $(-\mathrm{N})$ for $24 \mathrm{~h}$ or $48 \mathrm{~h}$. The absorption spectra were baseline corrected and normalized to the Chl peak.

In agreement with our absorption measurements, the $77 \mathrm{~K}$ fluorescence emission spectra also implied smaller antenna size of the photosystems in WT cells, especially after 48 h (Fig. 16) of nitrogen starvation. The reduced PBS level led to decreased EET to photosystems represented by lowered PSII fluorescence bands upon PBS excitation. Based on absorption spectra, the rate of PBS degradation seemed to be similar in the $c r t H$ strain to that of WT after $24 \mathrm{~h}$ nitrogen starvation (PBS to Chl ratio decreases from 0.80 to 0.55 ), but there was a pronounced difference after $48 \mathrm{~h}$ (Fig. 15) (0.36 PBS to Chl ratio). The absorption spectra of $c r t H$ cells after $48 \mathrm{~h}$ treatment implied almost twice as a high amount of phycobilins than in the WT suggesting lower degradation rate of phycobiliproteins. Interestingly, the $77 \mathrm{~K}$ fluorescence emission spectra of nitrogen deprived $\mathrm{crtH}$ cells upon 
$590 \mathrm{~nm}$ excitation revealed an increased intensity of the PC peak despite of the decrease in phycobilin content relative to Chl (Fig. 16).
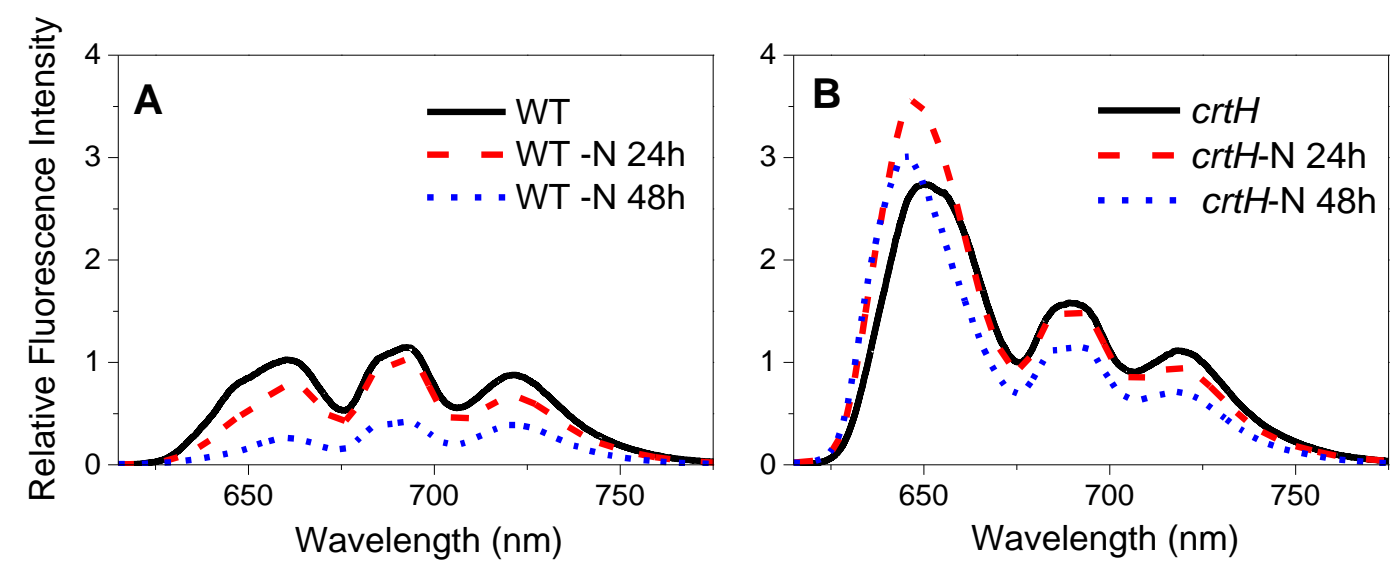

Figure 16. Effect of nitrogen starvation on $77 \mathrm{~K}$ fluorescence emission spectra of WT and $\mathrm{crtH}$ strains. Cells were cultivated on nitrogen-free media (-N) for $24 \mathrm{~h}$ or $48 \mathrm{~h}$. Fluorescence emission spectra were obtained upon $590 \mathrm{~nm}$ excitation and normalized on $720 \mathrm{~nm}$ band recorded upon $436 \mathrm{~nm}$ excitation.

The increase in the relative amount of the energetically disconnected PC subunits especially those which are in smaller aggregation form are resulting in the shift from $650 \mathrm{~nm}$ towards $640 \mathrm{~nm}$. However, the fluorescence emission spectra obtained upon $590 \mathrm{~nm}$ excitation were normalized; therefore, the increased PC peak did not necessarily indicate a higher level of unconnected rods on the cell basis.

We performed time-resolved fluorescence measurements with picoseconds (ps) time resolution on $\mathrm{crtH}$ mutant and WT cells incubated in nitrogen free media. This technique is useful to confirm the presence of undisturbed EET processes or to demonstrate the distortion of it. We have recorded fluorescence decays at various wavelengths upon $590 \mathrm{~nm}$ excitation before and after $24 \mathrm{~h}$ nitrogen starvation. The data were fitted as the sum of exponential decays. The wavelength distributions of the amplitudes corresponding to the individual decay components are called decay-associated spectra (DAS). Upon $590 \mathrm{~nm}$ excitation, the 
fluorescence decays exhibited at least five exponential decay components resolved by global analysis (Fig. 17). In WT cells, the fastest-decaying component reflects the downhill EET from $\mathrm{PC}$ to $\mathrm{APC}_{660}$ (Fig. 17A, blue curves). The second component (red curves) has a characteristic peak with a positive amplitude at shorter wavelengths and negative amplitude at longer wavelengths and therefore reflects the EET from $\mathrm{APC}_{660}$ to $\mathrm{APC}_{680}+\mathrm{Chls}$. The 170 ps component (yellow) reflects energy trapping by the RCs, which in turn shows the equilibrated EET over PBS subunits and Chls. The long lifetime components ( 534 ps, purple, and $\sim 1.42 \mathrm{~ns}$, green) have very small amplitudes. These components probably reflect the competition between secondary charge separation and charge recombination (Tian et al 2011).
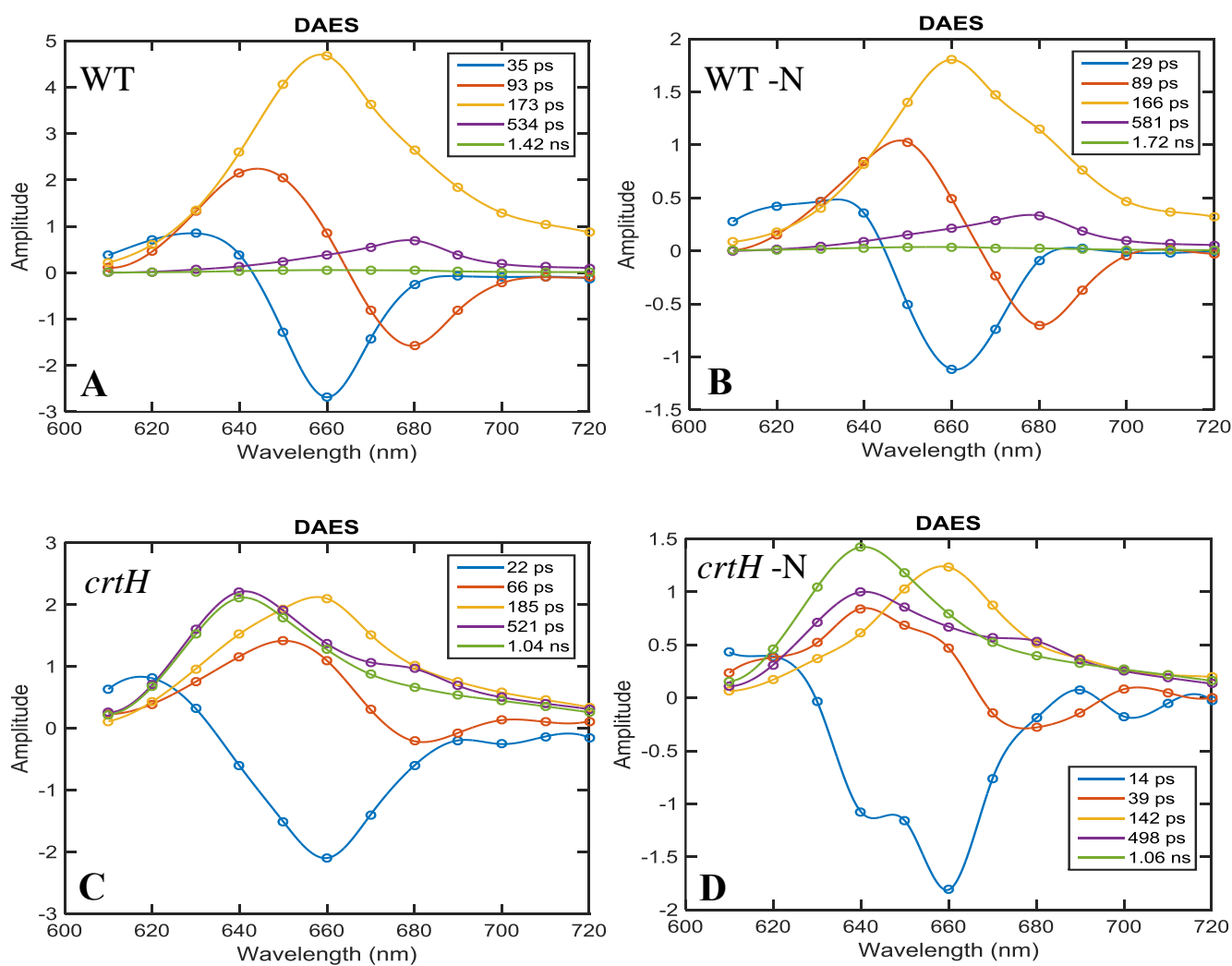

Figure 17. The decay-associated spectra of Synechocystis WT (A), WT -N (nitrogen free) (B), $c r t H(C)$ and $c r t H-\mathrm{N}$ (nitrogen free) (D) upon $590 \mathrm{~nm}$ excitation before and after (-N) $24 \mathrm{~h}$ of nitrogen starvation. The corresponding lifetimes are given in the figures. 
In our experiments even after $24 \mathrm{~h}$ of nitrogen shortage, the WT cells did not show any major changes in the EET only a slight change in the corresponding life-times (Fig. 17B). On the other hand, the obtained DAS for untreated $\mathrm{crtH}$ cells are strongly different from those of WT cells. In the $c r t H$ cells, a decrease in the amplitude of the red component reflects the decrease in energy transfer from PBS to the $\mathrm{APC}_{680}+$ Chls (Fig. 17C).

Most notably, the $\mathrm{crtH}$ cells were exhibited the dominant long living components, the purple and green components with $521 \mathrm{ps}$ and $1.42 \mathrm{~ns}$ lifetime and fluorescence maxima at around $640-650 \mathrm{~nm}$. These components originate from the functionally disconnected PC rods of PBS. Similar DAS for $c r t H$ mutant was obtained from the previous study in our laboratory (Toth et al 2015). In case of nitrogen shortage, the DAS of $c r t H$ cells displayed a component peaking around 640-650 $\mathrm{nm}$ wavelengths with even higher amplitude ( $1.06 \mathrm{~ns})$ (Fig. 17D) and no clear component for EET from was observed. These observations support the enrichment of the cells in energetically disconnected PC rods of PBS under nitrogen starvation.

Nitrogen starvation in carotenoids-deficient $c r t B$ cells was also monitored. The $c r t B$ cells can only grow in light-activated heterotrophic growth (LAHG) conditions (Sozer et al 2010), thus the PBS degradation induced by nitrogen starvation can be investigated without the possible influence of light. Prior to both the absorption and fluorescence emission measurements, the cultures were adjusted to the same $\mathrm{OD}_{750}$ value in order to compare the pigment content and corresponding fluorescence intensity on the cell basis. Based on the absorption spectra, the $\operatorname{crtB}$ cells possessed low $\mathrm{Chl}$ content relative to the amount of phycobilins (Fig. 18A). 

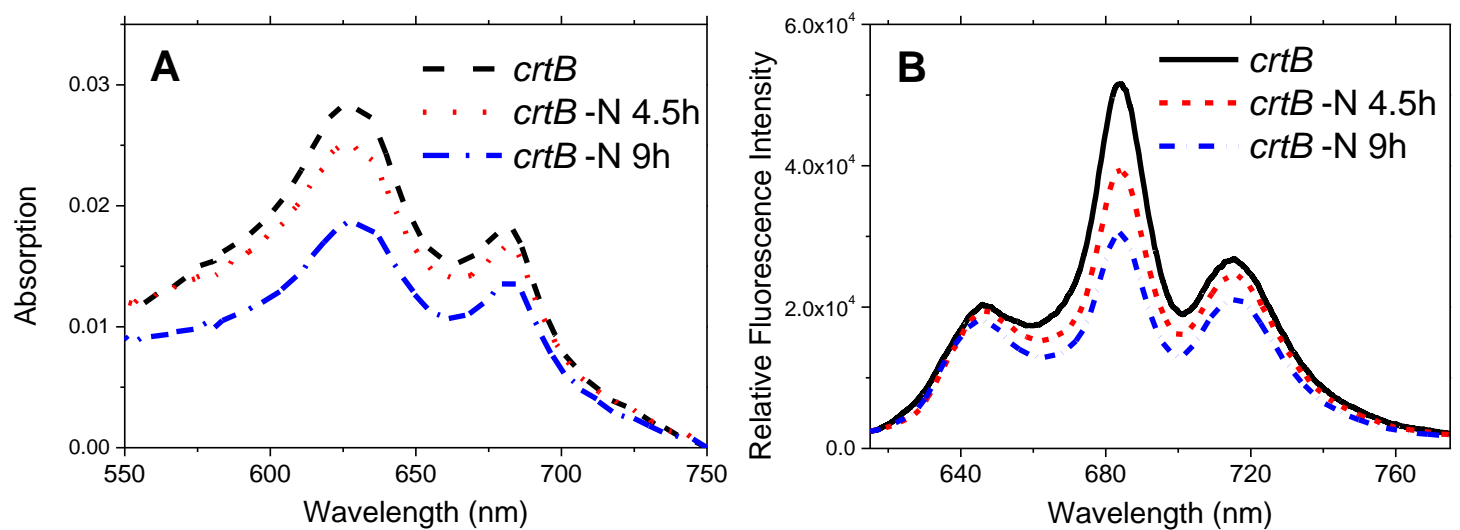

Figure 18. Effect of nitrogen starvation on the absorption and $77 \mathrm{~K}$ fluorescence emission spectra of $c r t B$ strains. Cells were cultivated on nitrate free media (-N) for $4.5 \mathrm{~h}$ or $9 \mathrm{~h}$. The absorption spectra (A) were obtained from cells possesses the same $\mathrm{OD}_{750}$ and baseline corrected. The fluorescence spectra (B) were recorded upon $436 \mathrm{~nm}$ excitation of cells with identical $\mathrm{OD}_{750}$.

Both the Chl and phycobilin related peaks showed a decrease after $4.5 \mathrm{~h}$ of nitrogen starvation which further reduced after $9 \mathrm{~h}$ treatment. In $\operatorname{crt} B$ cells similarly to WT, the absorption of phycobilins decreases faster than that of Chl. After $4.5 \mathrm{~h}$ treatment, the fluorescence emission spectra of the $c r t B$ cells (Fig. 18B) revealed a substantial decrease in the TE fluorescence emission, while PSI fluorescence only slightly lowered. After $9 \mathrm{~h}$ of nitrogen starvation, the TE peak and PSI peak further decreased, while the intensity of PC band remained almost at the original level.

The results from nitrogen starvation experiments could be explained by a slower degradation of unconnected PC rods, or an enhanced disassembly of PBSs upon $\beta$-carotene shortage in both the $c r t B$ and $c r t H$ strains. However, no fluorescence from TE of $c r t H$ cells appeared during the starvation, which supports the idea of the delayed degradation of PC rod units. This way, a role of $\beta$-carotene in the recognition or degradation of detached phycobiliproteins can be hypothesized. It is plausible that even under normal growth conditions, the degradation of unconnected rods is delayed to a certain extent; this delayed 
degradation of rods can result in the observed phenotype of the low $\beta$-carotene containing cells. The delayed degradation of detached PC units would also explain their increased presence in $c r t H$ cells grown under PMG conditions, where the cells have lower PBS and Chl content than under autotrophic conditions.

On the other hand, the delayed degradation of PC units itself would not explain the shorter rods of assembled PBSs. It is known that the degradation of PBSs is sequential (Schwarz \& Forchhammer 2005, Bernát et al 2009), thus the detachment of the last two rod units (Toth et al 2015) cannot be part of an active mechanism targeting to reduce the antenna size. Two mechanisms could explain such shortening of the rods. The detachment of the rods should occur even under non-stressed conditions (Anderson \& Toole 1998). In case of $\beta$ carotene shortage, there might be a defect of the PBS repair system. More likely, under $\beta$ carotene limitation PC detachment could occur due to damage of PBS linkers by a factor different from ROS. Indeed, cyanobacterial cells with linker protein deficiency accumulate a high level of disconnected phycobiliproteins (Anderson \& Toole 1998, Ughy \& Ajlani 2004), while the mutations related to the phycobiliprotein structure lead to a decreased amount of these proteins (Anderson \& Toole 1998). It seems that the cyanobacterial cells are unable to efficiently eliminate the disconnected PC oligomers although those have a capacity to produce harmful ROS (He et al 1997, Anderson \& Toole 1998). It is plausible that carotenoids participate in a complex similar to those formed by HLIP proteins (Knoppova et al 2014, Daddy et al 2015 ) and can protect the PBSs similarly to chaperons (Sato et al 2010). Thus, an important function of $\beta$-carotene may be the prevention of PBS disassembly. 


\subsection{Zeaxanthin and echinenone modify the structure of PSI trimer}

\subsubsection{Pigment analysis of cells and PSI complexes}

Firstly, we tested whether the xanthophyll deficiency influences the pigment content of PSI or if we can detect xanthophylls in the PSI complex of WT cells. We analyzed the pigment composition of whole cells and isolated PSI complexes by HPLC (Table 3).

Table 3. Relative distribution of the main carotenoid species from the whole cell extract, as well as isolated PSI trimers of WT, crtRO, crtR, crtO, cruF and monomers of psaL. Values are given as the number of pigment molecules relative to $100 \mathrm{Chl}$ molecules. Each value represents the mean ( \pm SD) of at least three independent repetitions. Abbreviation of carotenoids: Myx, myxoxanthophyll; Zea, zeaxanthin; Ech, echinenone; $\beta$-car, $\beta$-carotene. $*$ The result is significant at $\mathrm{P}<0.05$ or $* *$ at $\mathrm{P}<0.01$ as compared to WT using the t-test for equal variance.

\begin{tabular}{|c|c|c|c|c|c|c|c|}
\hline & \multicolumn{5}{|c|}{ Whole cells } & \multicolumn{2}{c|}{ Isolated PSI trimer/monomer } \\
\hline & Myx & Zea & Ech & $\beta$-car & Zea & Ech & $\beta$-car \\
\hline WT & $15.1 \pm 4.9$ & $21.1 \pm 2.2$ & $9.8 \pm 0.4$ & $26.0 \pm 0.9$ & $1.3 \pm 0.1$ & $8.0 \pm 0.9$ & $17.7 \pm 0.2$ \\
\hline crtRO & - & - & - & $34.3 \pm 0.1 * *$ & - & - & $23.2 \pm 1.0 * *$ \\
\hline crtR & - & - & $10.0 \pm 1.3$ & $21.6 \pm 1.1 * *$ & - & $9.2 \pm 1.2$ & $15.9 \pm 0.2 * *$ \\
\hline crtO & $7.9 \pm 1.4 *$ & $18.2 \pm 0.7 *$ & - & $38.6 \pm 2.9 * *$ & $1.5 \pm 0.18 *$ & - & $23.9 \pm 0.3 * *$ \\
\hline cruF & - & $27.1 \pm 2.7 *$ & $12.1 \pm 2.6$ & $30.3 \pm 1.2 * *$ & $1.5 \pm 0.2$ & $8.3 \pm 0.3$ & $17.6 \pm 0.2$ \\
\hline$p s a L$ & $9.1 \pm 1.9 *$ & $26.4 \pm 1.2 * *$ & $17.1 \pm 1.5 * *$ & $43.2 \pm 4.3 * *$ & $1.5 \pm 0.2 *$ & $7.2 \pm 0.3$ & $14.9 \pm 0.8 * *$ \\
\hline
\end{tabular}

Besides the almost completely xanthophyll-deficient (crtRO) mutant, we also investigated the PSI complex of $c r t R$, crtO and $c r u F$ mutants which are deficient in various xanthophyll species. Furthermore, we applied psaL mutant, which contains only PSI monomers due to the absence of the PsaL protein (Chitnis \& Chitnis 1993).

In order to minimize the amount of xanthophylls that co-purify, but unspecifically bind to PSI, $2 \% \beta$-DM was used for solubilization of the thylakoid membrane. Our data confirmed the presence of xanthophyll molecules, zeaxanthin and echinenone in the purified PSI complexes. In line with our findings, both zeaxanthin (Bautista et al 2005, Klodawska et 
al 2015, Komenda \& Sobotka 2016) and echinenone (Klodawska et al 2015, Daddy et al 2015) molecules were previously detected in Synechocystis PSI samples using lower (1\% $\beta$ DM) detergent concentration.

In spite of its large quantity in the cells, myxoxanthophyll was not observed in the isolated PSI complexes so far (Table 3) (Bautista et al 2005, Klodawska et al 2015). No compensation of the absence of echinenone by zeaxanthin was observed, but the echinenone deficiency (in $\operatorname{crt} O$ and $c r t R O$ ) coincided with an increase in the amount of $\beta$-carotene (Fig. 19) in the trimeric PSI complex.

The results are expressed relative to the Chl content, thus the increased amount of $\beta$ carotene in $\operatorname{crtO}$ and $\operatorname{crtRO}$ can be explained by a higher $\beta$-carotene content of the PSI (Fig. 19B) or a decrease in the Chl content of the complexes. The loss of peripheral Chl molecules during isolation of PSI complexes has been reported previously (Rogner et al 1990, ElMohsnawy et al 2010) and could provide a potential explanation for the apparent increase in the amount of $\beta$-carotene in the mutant PSI.
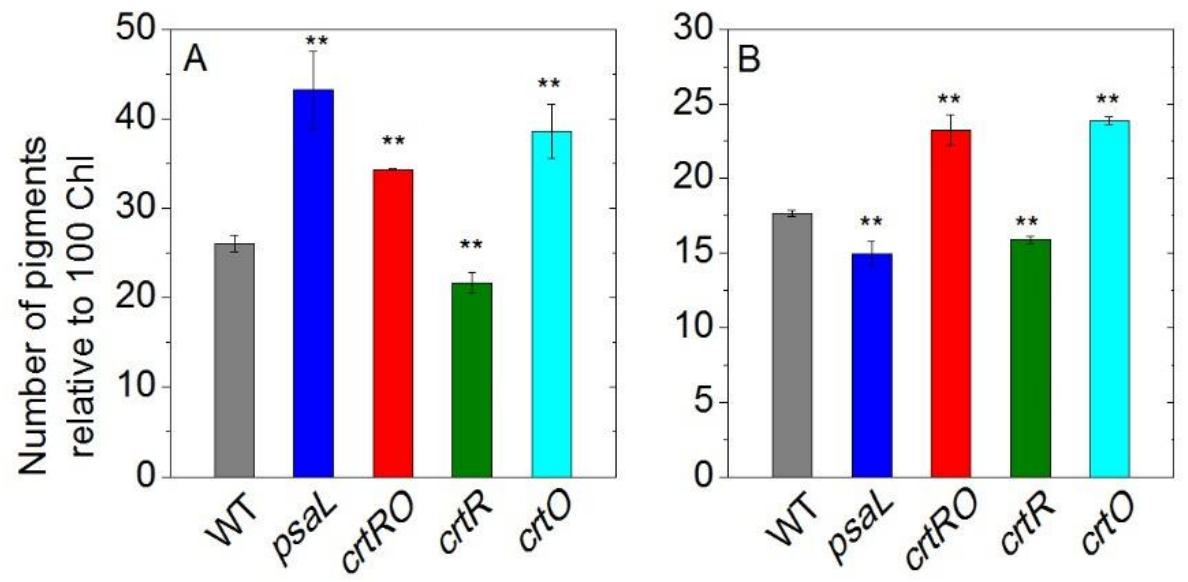

Figure 19. The $\beta$-carotene content of the whole cell extracts of WT, $\operatorname{crtRO}, \operatorname{crtR}, \operatorname{crt} O$, and psaL (A) and the corresponding PSI complexes (B). The values are given as the number of $\beta$ carotene molecules relative to $100 \mathrm{Chl}$ molecules. Each value represents the mean $\pm \mathrm{SD}$ of at least three independent repetitions. 
However, the Chl release should be accompanied by a parallel increase in the amount of zeaxanthin and $\beta$-carotene relative to $\mathrm{Chl}$ in the PSI of echinenone-deficient cells. In case of such degree of Chl loss, the Chl to protein ratio would substantially increase. We would expect around $30 \%$ increase in the $\mathrm{Chl}$ to protein ratio of echinenone or xanthophyll-deficient PSI relative to that of WT. However, we could not detect any significant difference in the Chl to protein ratio between PSI of crtRO and WT cells. These values were estimated as $3.02 \pm 0.06(n=3)$ and $3.13 \pm 0.09(n=3)$ for trimeric PSI of WT and the crtRO cells, respectively. In contrast, when the zeaxanthin synthesis was inhibited (in $\operatorname{crt} R$ ), a decrease of $\beta$-carotene was detected in the trimeric PSI complex. Due to the low amount of zeaxanthin in the PSI samples, it is difficult to see if the absence of zeaxanthin is compensated by echinenone.

The amount of $\beta$-carotene was also lower in PSI monomers of psaL cells (Fig. 19A). In the PSI monomers of $p s a L$ mutant, the reduced number of $\beta$-carotene molecules could be explained by the loss of those three $\beta$-carotenes which are involved in the binding of the PsaL protein to the PSI core (Grotjohann \& Fromme 2005, Toth et al 2015). Our earlier results did not reveal any change in the PsaL binding in the absence of xanthophylls, only when the cells were also deficient in $\beta$-carotene (Toth et al 2015). Therefore, the decrease in the $\beta$-carotene content of the isolated PSI trimer obtained from zeaxanthin-deficient cells probably represents the loss of $\beta$-carotene molecules different from those located at the trimerization domain.

Surprisingly, the amount of $\beta$-carotene (Table 3) showed the same tendency for the whole cells in the $\operatorname{crtRO}, \mathrm{crtR}$ and $\operatorname{crt} O$ genotypes as in the isolated PSI complexes. This effect could be explained by the fact that most of the $\mathrm{Chl}$ and $\beta$-carotene are associated with PSI due to the high abundance of PSI complexes. The same tendency of $\beta$-carotene levels 
was recorded in PSI complexes of the xanthophyll mutants $(\operatorname{crtRO}, \operatorname{crt} R, \operatorname{crt} O)$ at cellular level supporting that those differences in $\beta$-carotene to Chl ratio of PSI probably exist in vivo (Table 3) (Kusama et al 2015), as well. But for the psaL mutant where the decrease of the $\beta$ carotene content of PSI was accompanied by an increase of the cellular $\beta$-carotene level. This effect could be explained by the increased level of carotenoid-binding proteins (Daddy et al 2015).

\subsubsection{Testing the PSI organization by in vivo spectroscopic methods}

We addressed the question whether the absence of xanthophylls alters the organization of PSI in vivo. The circular dichroism (CD) and fluorescence measurements were proved to exhibit distinct spectral features for trimeric and monomeric PSI-containing samples both in vitro (Shubin et al 1993, Gobets et al 2001, El-Mohsnawy et al 2010, Karapetyan et al 2014 ) and in vivo (Klodawska et al 2015, Toth et al 2015) based on the specific pigment-protein interactions, the CD spectroscopy can be applied to investigate the role of xanthophylls in terms of structural rearrangement of PSI complex.

The circular dichroism (CD) spectra possess a characteristic fingerprint for PSI complex at around $515 \mathrm{~nm}$ wavelength based on specific pigment-protein interactions within the complex (Shubin et al 1993, Klodawska et al 2015, Zakar et al 2017). In this study, the CD spectra were obtained from cell suspensions of xanthophyll deficient mutant $\operatorname{crtRO}$, and psaL relative to that of WT and revealed differences in the $515 \mathrm{~nm}$ peak (Fig. 20A). The PSIrelated signal was expressed by the CD amplitudes measured at $515 \mathrm{~nm}$ using a reference wavelength of $550 \mathrm{~nm}$. Values are also given in percentage (Fig. 20B), where 0\% corresponds to the level of $515 \mathrm{~nm}$ signal in the psaL (only PSI monomers) and $100 \%$ to that in WT (predominantly PSI trimers). 

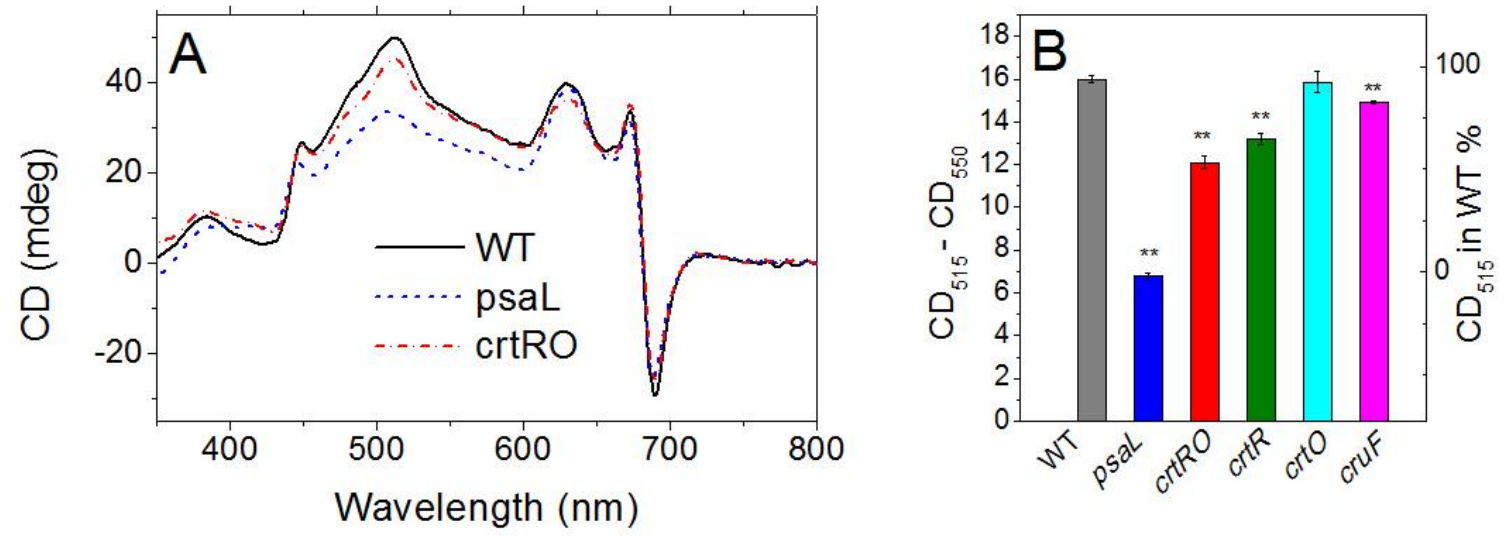

Figure 20. Circular dichroism spectroscopy analysis of WT and various mutants of Synechocystis cells. A: Overlaid CD spectra of psaL, crtRO, and WT cells. The spectra were normalized to the $\mathrm{Chl}$ absorption measured at $680 \mathrm{~nm}$. B: Comparison of the amplitudes of the PSI-related $515 \mathrm{~nm}$ bands. Error bars represent standard deviation. * The result is significant at $\mathrm{P}<0.05$ or $* *$ at $\mathrm{P}<0.01$ as compared to $\mathrm{WT}$.

In our experiments, the PSI-related CD signal did not decrease in $\operatorname{crtO}$ and only to a small extent in cruF cells, while approximately $30 \%$ and $40 \%$ reduction of the PSI signal was observed in $c r t R$ and $c r t R O$ cells, respectively. Thus, mostly the absence of zeaxanthin could be accounted for the decrease in the PSI-related CD signal observed in vivo upon complete xanthophyll deficiency.

The CD spectra were normalized to the total Chl absorption of the cell suspensions; consequently, any changes in the PSI to PSII ratio of cells could alter the intensity of the PSIrelated CD signal. The influence of xanthophyll content on PSI to PSII ratio was investigated by the fluorescence emission of cells upon Chl (436 nm) excitation (Fig. 21) at low temperature. This way both PSI and PSII are excited and any changes in the relative ratio of fluorescence emitted by the photosystems suggest the alteration of their approximate ratios. The spectra of the strains investigated in this study exhibited no or only a small (less than 5\%) decrease in PSII peaks (685 and $695 \mathrm{~nm})$ relative to the PSI band $(720 \mathrm{~nm})$. 
The spectra were obtained from dark-adapted cells, thus the effect of light-induced non-photochemical quenching on the intensity of the PSII peaks should not be considerable. In line with these results, the time-resolved fluorescence measurements also did not reveal any significant changes in the fluorescence lifetimes of the photosystems (Toth et al 2015). Therefore, the difference observed in the CD spectra of the cells cannot be strongly influenced by the change in the PSI to PSII ratio of the mutants.

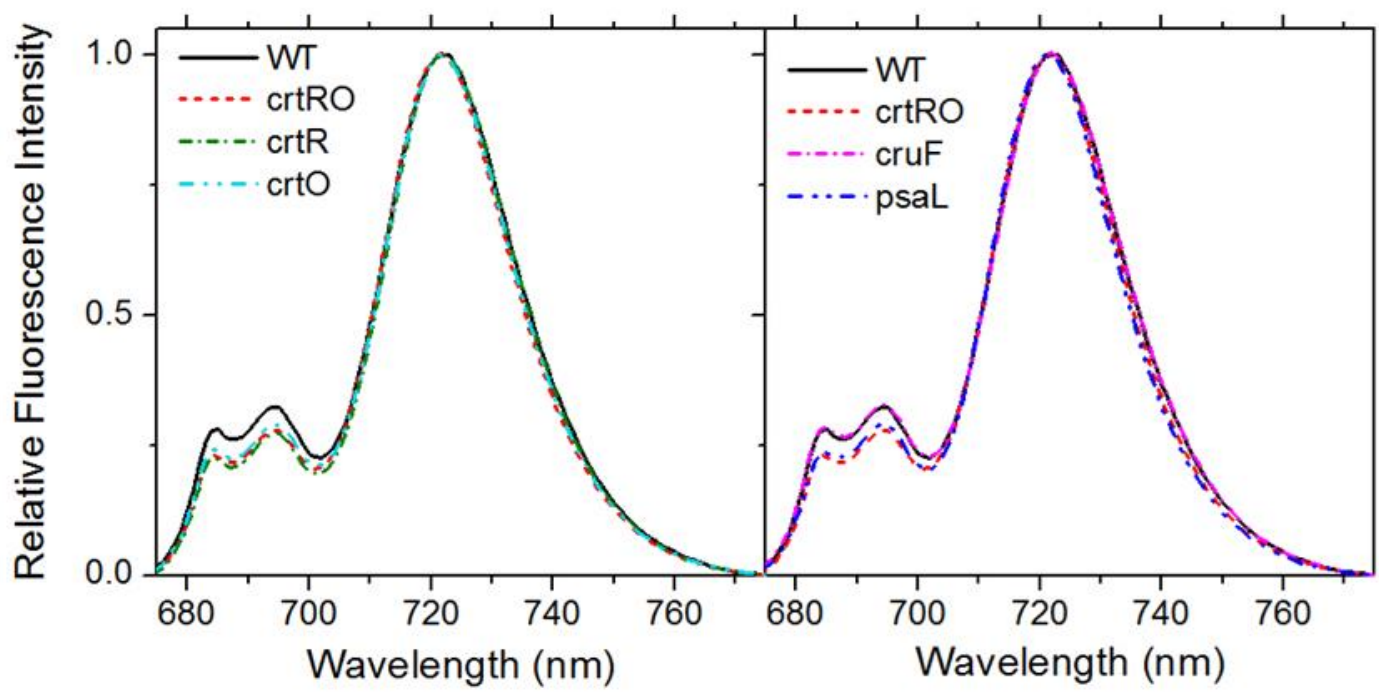

Figure 21. 77K fluorescence emission spectra of Synechocystis WT and $\operatorname{crtRO}, \operatorname{crtR}, \operatorname{crtO}$, $c r u F$ and psaL mutant cells. The spectra were recorded upon $436 \mathrm{~nm}$ excitation of samples with equivalent $\mathrm{Chl}$ content and normalized to their maxima.

The fluorescence technique was also useful to obtain further information about the PSI trimer in vivo, based on the spectroscopic feature of the LWCs. Although LWCs are responsible for only a small fraction of the total absorption, they have a strong effect on the fluorescence properties of the PSI, especially when recorded at low (77K or less) temperature (El-Mohsnawy et al 2010). Around five-six LWCs in the trimer and three-four in the monomer of Synechocystis were proposed based on experimental results (Gobets et al 2001, Mazor et al 2014). These LWCs absorb light around $700 \mathrm{~nm}$ and emit fluorescence above 710 nm depending on temperature (van der Lee et al 1993, Gobets et al 2001, Karapetyan et al 
2014). Hence, here we recorded fluorescence emission at $77 \mathrm{~K}$ temperature to obtain information about the level of PSI trimer in vivo, based on the "red" Chl interaction. According to our results, a decrease in the LWC signal was observed not only in psaL but also in $\operatorname{crtRO}$ cells (Fig. 22A).
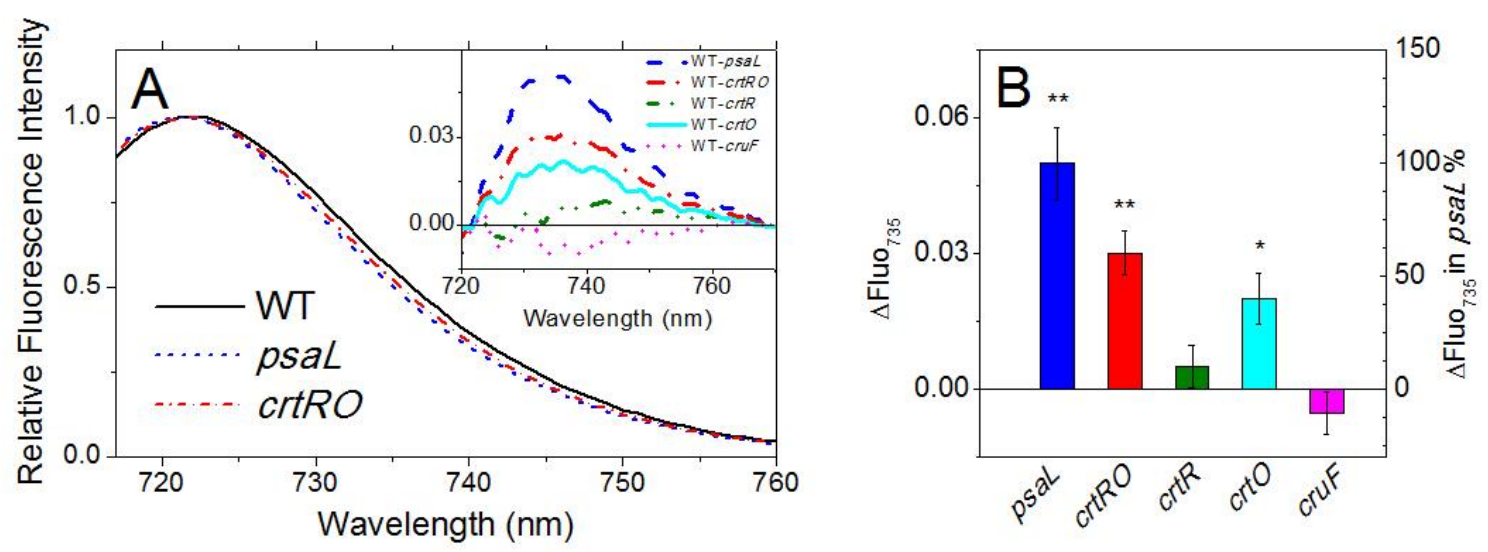

Figure 22. 77K fluorescence emission spectra recorded on WT and mutant Synechocystis cells. A: The spectra were recorded upon $436 \mathrm{~nm}$ excitation of samples with equivalent $\mathrm{Chl}$ content and normalized to their maxima. The inset shows the WT minus mutant difference spectra for various cells. B: Difference in the fluorescence emission between the WT and mutants at $735 \mathrm{~nm}$. Error bars represent standard error $(\mathrm{n}=3)$. * The result is significant at $\mathrm{P}<$ 0.05 or $* *$ at $\mathrm{P}<0.01$ as compared to WT.

We found around $60 \%$ decrease in the amplitude of the LWC signal obtained from the crtRO mutant (Fig. 22B), in conditions when WT and psaL represent 0\% and $100 \%$, respectively. Our results showed around $45 \%$ reduction of the LWC signal in crtO cells, and no significant difference $(\mathrm{P}>0.05)$ in $c r t R$ and $c r u F$ cells. Consequently, mostly the CrtO mutation contributed to the PSI-assigned fluorescence change observed in the crtRO mutant.

The changes of the PSI-related CD signal do not essentially coincide with alteration of the LWC fluorescence of the PSI (Fig. 20 and 22). Based on these results, we suppose that both zeaxanthin and echinenone influence the structure of PSI, specifically, in a different manner in vivo. In order to support our hypothesis biochemical investigation of the xanthophyll-deficiency-induced effect on PSI were carried out. 


\subsubsection{Protein analysis of the thylakoid membrane}

To investigate the importance of the specific xanthophylls in the organization of PSI trimer, protein analysis was performed on the same set of mutants. We applied CN-PAGE (Fig. 23) which allows comparing the intensity of Chl-containing bands. Identification of the bands on the gel was performed based on the relative electrophoretic mobility (Kopecna et al 2012, Toth et al 2015).

A

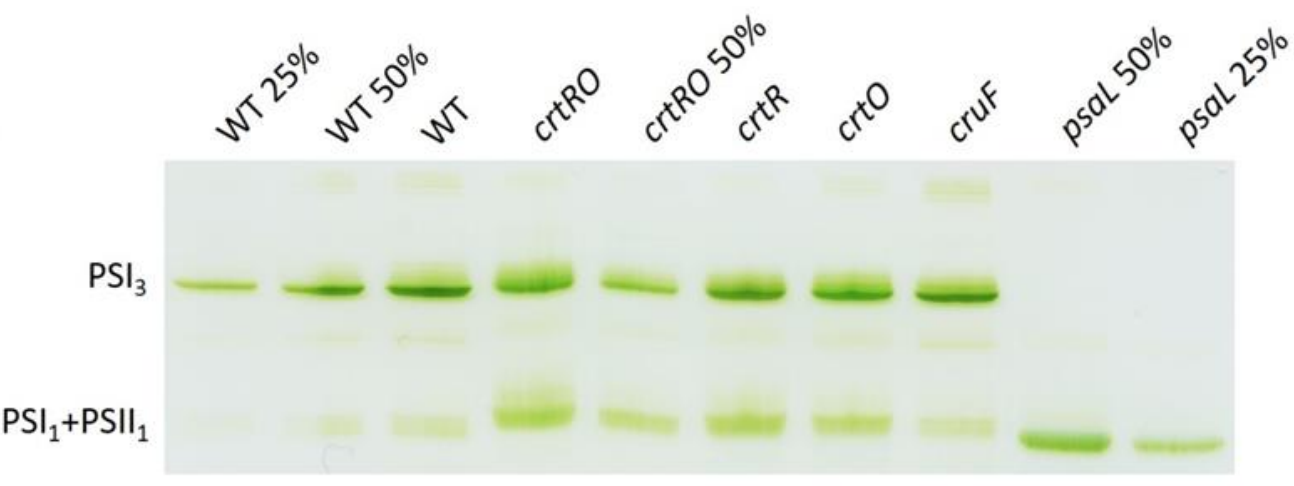

B

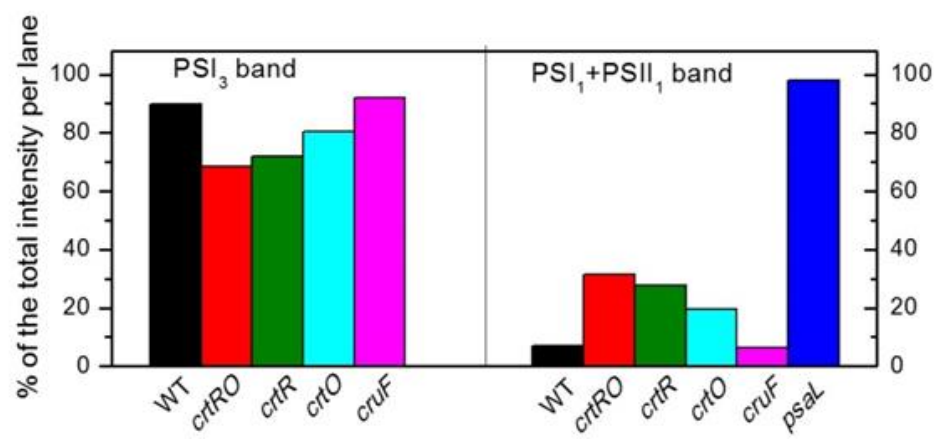

Figure 23. CN-PAGE analysis of thylakoid membrane protein complexes of various xanthophyll biosynthesis mutants. A: Thylakoid membranes of WT, crtRO, crtR, $c r t O, c r u F$ and psaL cells were solubilized with $1 \% \beta$-DM (w/v). Samples containing 1, $0.5(50 \%)$ or $0.25(25 \%) \mu \mathrm{g}$ of Chl were loaded, as it is indicated. The positions of PSI trimeric or PSI and PSII monomeric complexes are indicated in the left side. B: Quantitative densitometry results for the Chl-containing protein bands separated by the CN-PAGE. The results obtained from the same sample loaded at various concentrations have been averaged after normalization.

Thylakoid sample of the psaL mutant with $50 \%$ and $25 \%$ of Chl concentration was loaded on the gel to achieve a better assessment of the amount of monomers in the mutant cells. It is noteworthy, that most of the Chl molecules (approximately 90\%) bound to PSI; thus, the intensity changes of the green bands are well correlating with the alterations in PSI 
organization. In our experiments, the electrophoretic separation of native protein complexes revealed a somewhat higher amount of monomers at the expense of PSI trimers in $\operatorname{crtRO}$, $c r t R$, and $c r t O$ thylakoids, but these monomeric PSI bands were still much fainter than that of the two-fold diluted psaL sample (Fig. 23A). Based on densitometry results, the crtRO, crtR, and $\operatorname{crtO}$ mutants exhibited around $25 \%$ increase in the intensity of the monomeric band relative to the WT independently of the applied Chl concentration (Fig. 23B).

The stability of PSI trimers was also tested using various treatments, like EDTA washing, increased detergent concentration and high temperature (Fig. 24). We found that the PSI trimer of xanthophyll-deficient $\operatorname{crtRO}$ mutant possessed a strongly increased propensity for decomposing into monomers, as compared to WT upon EDTA treatment. Due to technical limitations, the detailed structure of PSI trimer has only been obtained from $T$. elongatus (Jordan et al 2001), while the only partial structure of PSI monomer is available from Synechocystis PSI complex (Mazor et al 2014).

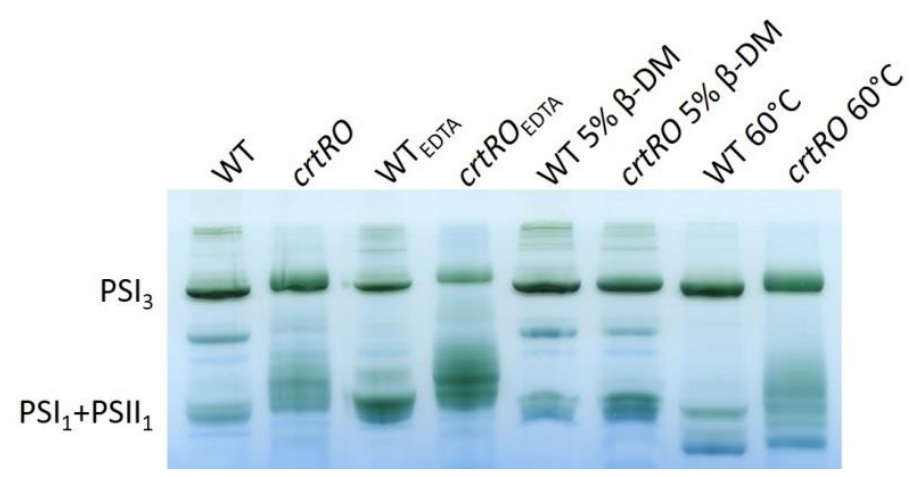

Figure 24. Protein analysis of Synechocystis thylakoid membrane of WT and the xanthophyll-deficient mutant, crtRO by BN-PAGE. The membranes of WT and crtRO mutant were solubilized with $1 \% \beta$-DM (w/v) and treated with $25 \mathrm{mM}$ EDTA, 5\% $\beta$-DM or $60^{\circ} \mathrm{C}$ heat where indicated. Samples containing $2.5 \mu \mathrm{g}$ of Chl were loaded on each lane. The positions of PSI trimeric ( $\left.\mathrm{PSI}_{3}\right)$, PSI and PSII monomeric $\left(\mathrm{PSI}_{1}+\mathrm{PSII}_{1}\right)$ complexes are indicated on the left side.

The high-resolution structure supposes a $\mathrm{Ca}^{2+}$ ion in the PSI trimeric complex which is released during the transition of trimer to monomers (Jordan et al 2001). Based on the 
structural homology of PSI between Synechocystis and T. elongatus, we assume that in our experiments, the structural differences at the monomer-monomer interface in the absence of xanthophylls could lead to the easier release of $\mathrm{Ca}^{2+}$ and eventually the disassembly of the trimer into monomers. This hypothesis is supported by the substantial sensitivity of the mutant trimer to the chelating agent, EDTA (Fig. 24). Thus, a weaker binding of divalent cations (i.e. $\mathrm{Ca}^{2+}$ ) in the absence of xanthophylls can be accounted for the reduced PSI trimer stability. However, PSI trimer was not showing increased susceptibility to other factors (e.g. detergent, high temperature). Interestingly, in $\operatorname{crtRO}$ samples, the PSI monomers exhibited multiple bands with poor resolution upon solubilization with $1 \% \beta$-DM, while separated into one distinct band after solubilization with 5\% $\beta$-DM (Fig. 24). This suggests a modified interaction of the monomeric PSI with the surrounding lipid molecules

We performed sucrose density gradient centrifugation during purification of the PSI complexes from solubilized thylakoids. Mostly, trimeric PSI was obtained from the WT and cruF mutants, while only monomers were observed in psaL samples (Fig. 25). Surprisingly, our results revealed an extreme instability of the trimeric PSI complexes in $c r t R O$ and $c r t R$ mutants under these conditions and to some extent in $\operatorname{crt} O$. In $\operatorname{crt} R O, \operatorname{crt} R$ and $\operatorname{crtO}$ samples the ratio of PSI trimers to monomers varied from isolation to isolation (Fig. 25 and 26); but in crtRO mutant cells, we could not retain more than $50 \%$ of the trimers. These observations correlate with the changes observed in CN and BN-PAGE (Fig. 23 and 24), but show a more pronounced effect. 


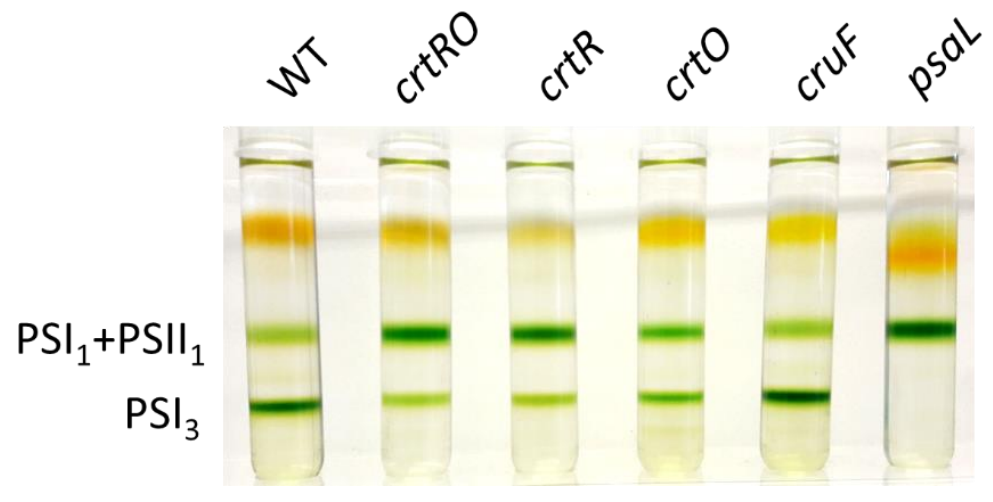

Figure 25. Sucrose density gradient fractionation of solubilized thylakoid membranes. Thylakoid membranes were solubilized by $2 \% \beta$-DM and samples with equivalent $\mathrm{Chl}$ content were loaded onto each tube. The band designation is indicated next to the corresponding bands.

These results also demonstrate a weakening of the driving force responsible for maintaining the trimeric structure upon the absence of xanthophylls. It seems that the instability of the PSI trimer of $\operatorname{crtRO}$ mutant is mostly due to the $\operatorname{crtR}$ and, at less extent, to the crtO mutation. Accordingly, predominantly zeaxanthin and, in a certain degree, echinenone could be accountable for the stabilization of the PSI trimeric complex.

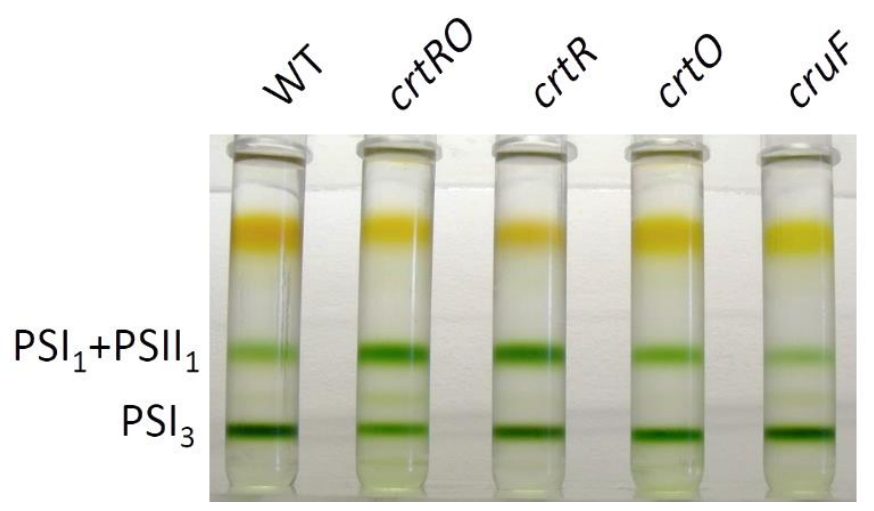

Figure 26. Sucrose density gradient fractionation of solubilized thylakoid membranes. Thylakoid membranes were solubilized by $2 \% \beta$-DM and samples with equivalent Chl content was loaded onto each tube. The band designation is indicated next to the corresponding bands.

Such important role of xanthophylls in the trimeric structure of Synechocystis PSI raises the question as to where those structurally important xanthophylls are located and how 
they influence the protein structure. Although it was observed that some carotenoid-binding proteins can also bind xanthophylls (Melnicki et al 2016), it is unlikely that those are copurified with PSI complexes. However, the influence of certain membrane-localized carotenoid molecules on the structure and function of membrane proteins was previously demonstrated (Chegeni et al 2016, Janik et al 2016). Such effect of non-protein-bound xanthophylls on the PSI trimer structure could occur via their influence on the lipid environment in the vicinity of the complex e.g. modifying the width or fluidity of the membrane (Gruszecki \& Strzalka 2005, Klodawska et al 2015) or via direct interaction of the peripheral xanthophylls with specific parts of the transmembrane protein domains. In fact, the impact of the membrane lipid compositions on the xanthophyll content and PSI oligomerization was already established in Synechocystis cells (Domonkos et al 2009, Zakar et al 2017).

\subsubsection{Spectroscopic investigation of the PSI complexes}

We have investigated the PSI trimeric complex in vivo by spectroscopic methods in order to reveal the location of structurally important xanthophylls in the PSI complex and understand how they influence it. Our idea of structurally modified PSI trimers was confirmed in vitro by the CD spectra of the PSI complexes separated by native gel electrophoresis (Fig. 27). The difference between PSI trimer of WT and monomer of psaL spectra was similar to what was observed for whole cells. Moreover, trimers of both the $c r t R O$ and $c r t R$ retained their spectral difference from WT, while $c r t O$ and $c r u F$ are still do not differ significantly (Fig. 27A). 

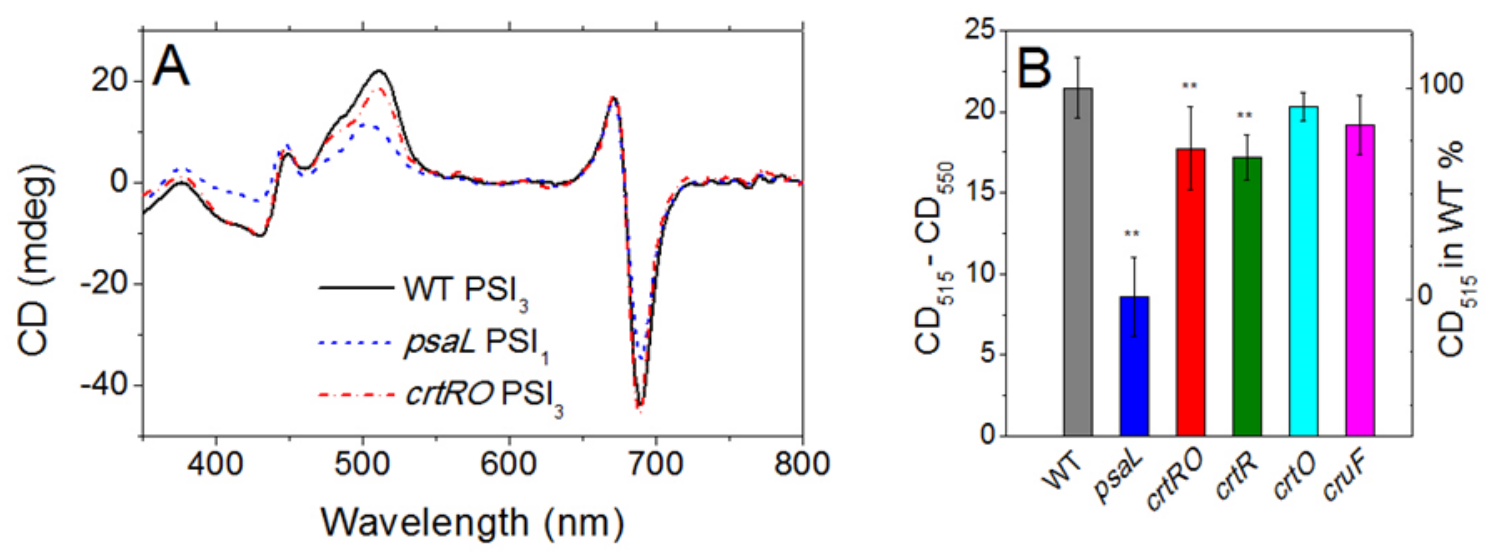

Figure 27. Circular dichroism spectroscopy analysis of PSI complex of WT and various mutants of Synechocystis cells. The thylakoid membranes were solubilized by $1 \% \beta$-DM. A: Overlaid CD spectra of CN-PAGE separated PSI complex of psaL, crtRO, and WT. The spectra were normalized to the $\mathrm{Chl}$ absorption measured at $680 \mathrm{~nm}$. B: Comparison of the amplitudes of the PSI-related $515 \mathrm{~nm}$ bands. Error bars represent standard deviation. ** The result is significant at $\mathrm{P}<0.01$ as compared to $\mathrm{WT}$.

Similar results were obtained on sucrose density gradient fractions containing dominantly PSI complexes (Fig. 28). Thus, specific action sites for the xanthophylls at the PSI complex were predicted from the spectroscopic results.

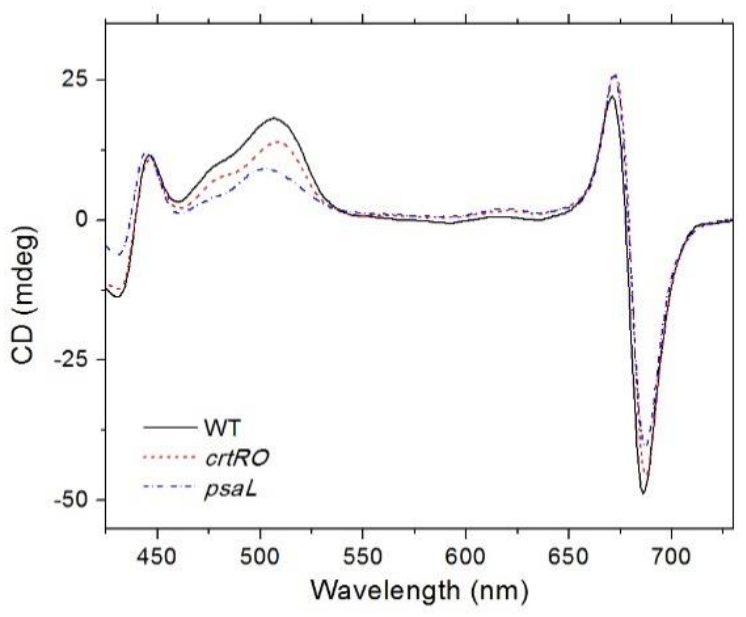

Figure 28. Circular dichroism spectroscopy analysis of thylakoid membranes isolated from WT, crtRO, and psaL cells. The spectra were normalized to the Chl absorption measured at $680 \mathrm{~nm}$. 
The pigment analysis revealed the same amount of xanthophylls per trimer as in the monomer (see section 4.2.1) in spite of the high (2\%) detergent concentration. We have also tested by spectroscopic methods the PSI trimeric complexes isolated by a multistep purification method (sucrose density gradient followed by anion exchange chromatography) from thylakoid membrane solubilized with higher detergent concentration ( $2 \% \beta$-DM). Under these conditions, the $\mathrm{CD}$ spectrum of $c r t R O$ trimer appeared to be almost identical to the WT one (Fig. 29A).

On the other hand, the similar difference between WT trimer and psaL monomer was observed, as it was previously observed for these oligomers of PSI (Fig. 29A) (Shubin et al 1993).
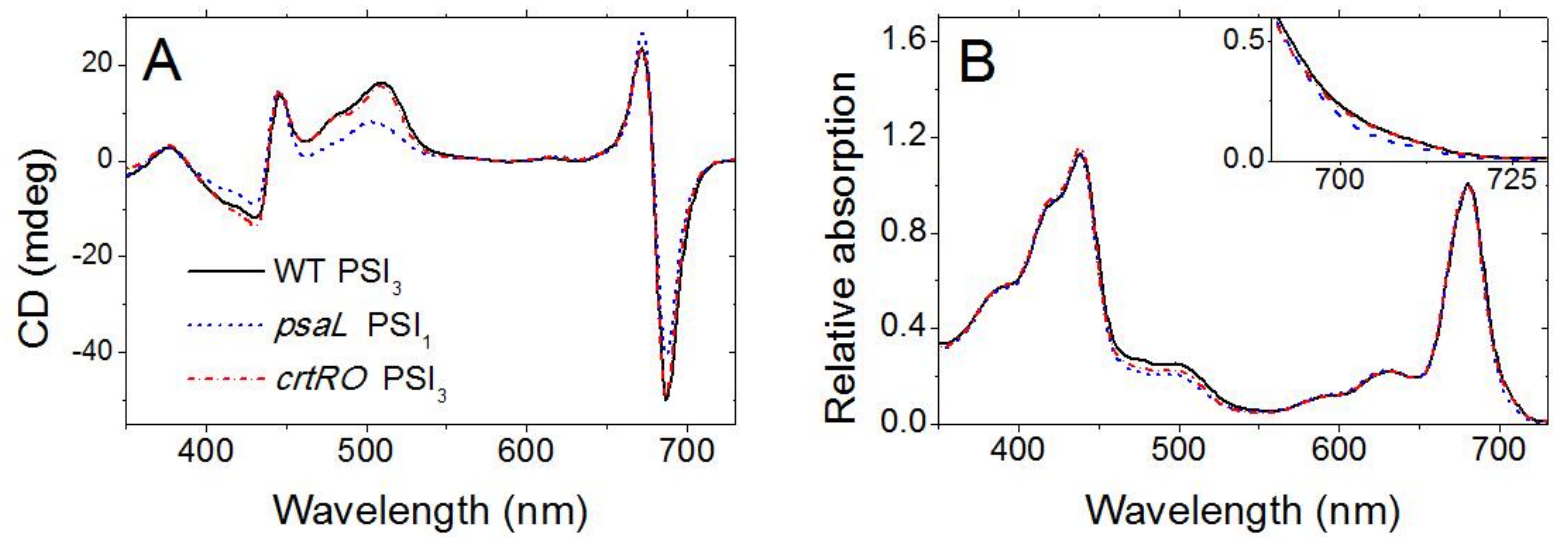

Figure 29. Spectroscopic analysis of PSI complexes obtained by multistep isolation. The thylakoid membranes were solubilized with $2 \% \beta$-DM. A: Circular dichroism spectra of the PSI complexes. The spectra were normalized to the Chl absorption at $680 \mathrm{~nm}$. B: Absorption spectra of the trimeric PSI isolated from WT and $\operatorname{crtRO}$ overlaid with the spectrum of monomeric PSI from psaL. The inset shows the absorption region of the LWCs.

In order to monitor the presence of LWCs, we recorded the absorption spectra of the trimeric PSI from WT and crtRO, as well as the PSI monomer of psaL cells (Fig. 29B). Interestingly, the absorption spectrum of crtRO PSI trimer also did not show any difference from WT trimer in the region of $690-720 \mathrm{~nm}$, while PSI monomer of psaL has a lower 
absorbance at this range (Fig. 29B). Thus, the PSI complexes seemed to undergo structural modification during multistep isolation, which eventually can lead to the loss of the spectral difference between WT and xanthophyll-deficient PSI trimers (Fig. 29). Based on our observations, we predict the presence of the xanthophylls in the peripheral part of the protein in the membrane plane where they can also interact with the surrounding lipid molecules.

We suppose that xanthophylls are performing mostly fine regulation of the PSI structure. Very recently, our predictions regarding the presence of zeaxanthin and echinenone molecules in the PSI trimeric complex of Synechocystis were confirmed by X-ray crystallography (Malavath et al 2018). The high resolutions structure of the partial (subunit depleted) PSI trimeric complex was obtained. Their measurements suggest at least 4 zeaxanthin and 7 echinenone and one hydroxyl-echinenone molecule in the PSI trimeric complex. Their data also support the presence of the xanthophylls mostly at the periphery of the monomeric complexes.

Furthermore, our experiments on the isolated trimeric PSI complex of T. elongatus also suggest that around two molecules of zeaxanthin and echinenone are present per PSI monomer (Table 4).

Table 4. Relative distribution of the main carotenoid species of PSI trimers isolated from WT Synechocystis and T. elongatus. Values are given as the number of pigment molecules relative to $100 \mathrm{Chl}$ molecules. Each value represents the mean $\pm \mathrm{SD}$ of at least three independent repetitions.

\begin{tabular}{|l|c|c|c|}
\hline & Zea & Ech & $\beta$-car \\
\hline Synechocystis PCC 6803 & $1.3 \pm 0.1$ & $8.0 \pm 0.9$ & $17.7 \pm 0.2$ \\
\hline Thermosynechococcus elongatus & $2.1 \pm 0.3$ & $1.7 \pm 0.3$ & $24.3 \pm 3.0$ \\
\hline
\end{tabular}

Based on the sequence homology, the structure of PSI complexes are very similar in various cyanobacterial species; this predicts that the involvement of xanthophylls in the stabilization of the complexes could be a more general phenomenon, not specific for 
Synechocystis strain. Our previous measurements in the xanthophyll-deficient mutant of Synechocystis revealed slightly lower stability of PSII dimer as well (Toth et al 2015). Thus, the analogous effect of xanthophylls on both photosystems is plausible, but its confirmation requires further studies on the PSII structure and its related functions. 


\section{SUMMARY}

The dissertation is focused on the role of carotenoids in the assembly, structure, and function of cyanobacterial photosynthetic complexes, namely the phycobilisome (PBS) antenna and photosystem I (PSI) trimer. Cyanobacteria are widely studied and important group of photosynthetic organisms; they are a major class of primary biomass producers and represent a taxonomic group closely related to the common ancestor of oxygenic photosynthetic organisms. Cyanobacteria are the only prokaryotic oxygen-evolving organisms and are also easily amenable to genetic engineering approaches (used in this thesis) while having the potential for industrial biofuel applications as well.

\section{i. $\quad \beta$-carotene influences the phycobilisome structure}

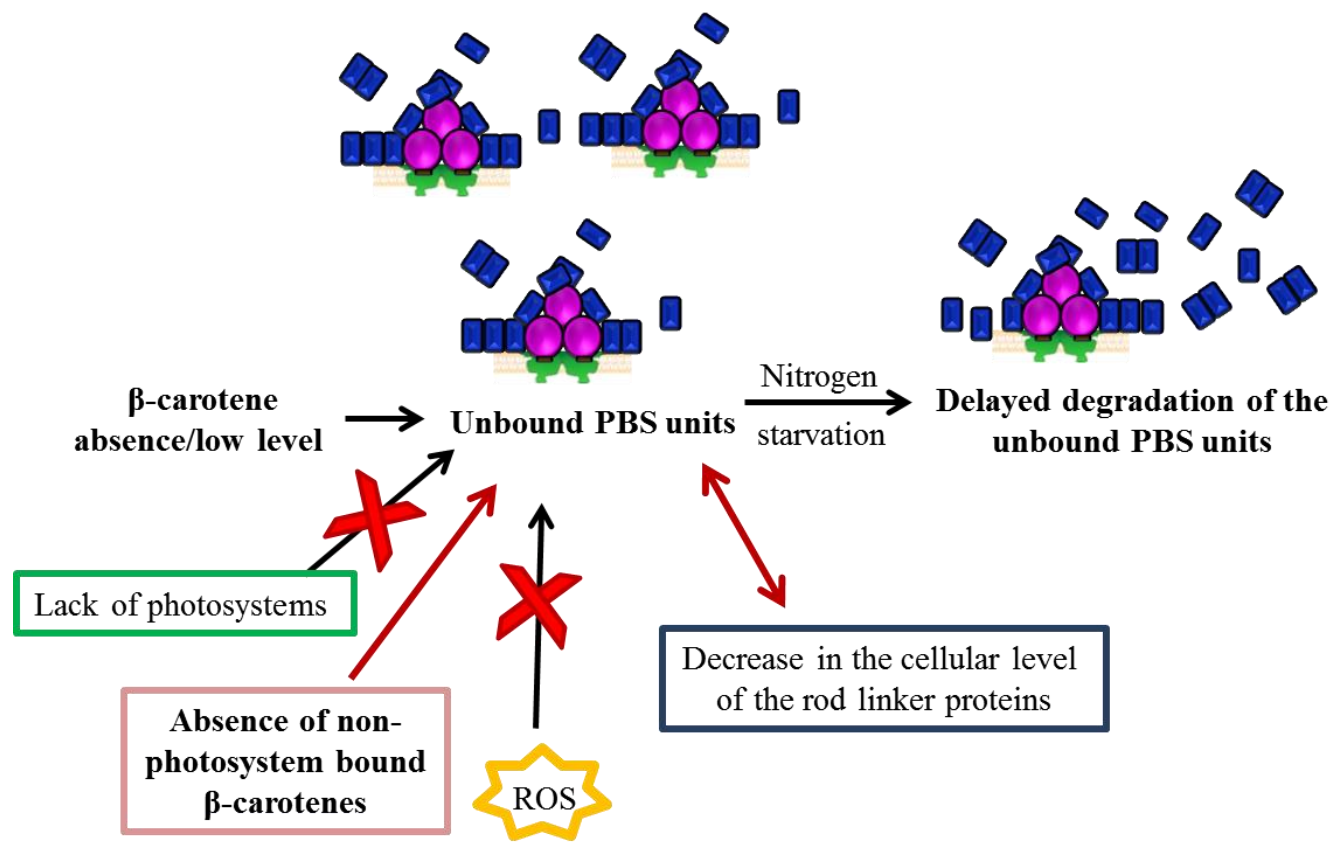

(Reactive oxygen species) 
In the first part of the thesis, we have investigated the relationship between the carotenoid composition and the structure of PBS antenna. It was previously found that the complete carotenoid deficiency ( $c r t B$ cells) and also the low level of carotenoids ( $c r t H$ cells) resulted in the presence of disconnected PC rods of PBS besides the assembled PBSs with shorter rods. We have proved with a set of mutants, including a newly generated myxoxanthophyll deficient mutant ( $c r u F$, in this thesis), that none of the xanthophylls could significantly influence the structure of PBS. It is generally known that most of the $\beta$-carotene is bound to the photosystems. Although the absence of photosystems was observed upon the complete carotenoid deficiency, we showed that it does not affect the PBS structure. Thus, a small fraction of $\beta$-carotene, which is not connected to the photosystems, is important for the properly assembled PBS.

The presence of unconnected rod units could be explained by the absence or improper function of the rod linker proteins which connect the PC rods to the rest of the PBS complex. We found that the amounts of these linker proteins were reduced at the cellular level in the complete carotenoid deficient mutant $(\mathrm{crtB})$. Thus, a higher rate of degradation or inhibition of linker protein synthesis can occur upon $\beta$-carotene shortage and results in the altered PBS structure. The complete carotenoid deficient ( $\operatorname{crtB}$ ) mutant possesses an extreme light sensitivity and does not show photosynthetic activity. On the other hand, the cells with lower carotenoid content ( $\mathrm{crtH}$ mutant) possess the same PBS related distortion as the complete carotenoid deficient cells ( $c r t B)$ without severe effects on the basic photosynthetic functions. In order to decrease the complexity of our model system, the mutant with lower carotenoid content was used in most of the further experiments for understanding the correlation between $\beta$-carotene and PBS structure. 
One of the main functions of carotenoids is the protection against ROS induced damage. The effects of $\beta$-carotene shortage on the PBSs are in fact can be caused by an increased production of ROS. Accordingly, the cells with lower carotenoid content $(\mathrm{crtH})$ exhibited an increased production of a harmful ROS, so-called ${ }^{1} \mathrm{O}_{2}$. These cells were also more susceptible to high light treatment but displayed a higher tendency for complete degradation of PBSs rather than the increased accumulation of disconnected PC rods. In spite of the fact that the mutant cells possess a lower amount of carotenoids, they contain a similar level of myxoxanthophyll as wild-type cells. The remaining myxoxanthophyll could ensure the ROS protection of the PBS linker proteins in this mutant. This hypothesis was conclusively rejected by the use of the newly created double mutant (crtH/cruF, in this thesis), which also lacks myxoxanthophyll. Based on our observations, we propose that ROS induced direct damage is unlikely to cause a significant reduction in the level of the PBS rod linker proteins upon limited $\beta$-carotene availability.

As a next approach, the enzymatic PBS degradation was induced by the nitrogen starvation condition in the mutants ( $c r t H$ and $c r t B)$ possessing disconnected PBS units. During nitrogen-limited conditions, the wild-type cells degrade their phycobiliproteins through a programmed pathway to release the composing nutrients and ensure the survival of cells. Surprisingly, a slower degradation of the disconnected PBS units was observed in the mutants under the nitrogen shortage. Consequently, our results suggest that the increased amount of unconnected PC units upon limited $\beta$-carotene availability is most probably due to an insufficient degradation rate of phycobiliproteins and/or an increased disassembly of PBS.

\section{ii. Zeaxanthin and echinenone modify the structure of photosystem I trimer}

In the second part of this thesis, the function of xanthophylls in the organization and structure of PSI trimer was demonstrated. Our pigment analysis confirmed the presence of 
xanthophylls, namely zeaxanthin and echinenone in the PSI trimeric complex. Both the zeaxanthin and echinenone molecules can be part of the complex or be embedded in the membrane in the vicinity of PSI. Despite the presence of a high amount of myxoxanthophyll in the cells, we could not observe it in the isolated complex, thus only specific xanthophyll molecules are present in PSI. In the xanthophyll-deficient mutant, a compensatory increase in the level of $\beta$-carotene was observed, which suggest that xanthophylls might have important functions in the complex.

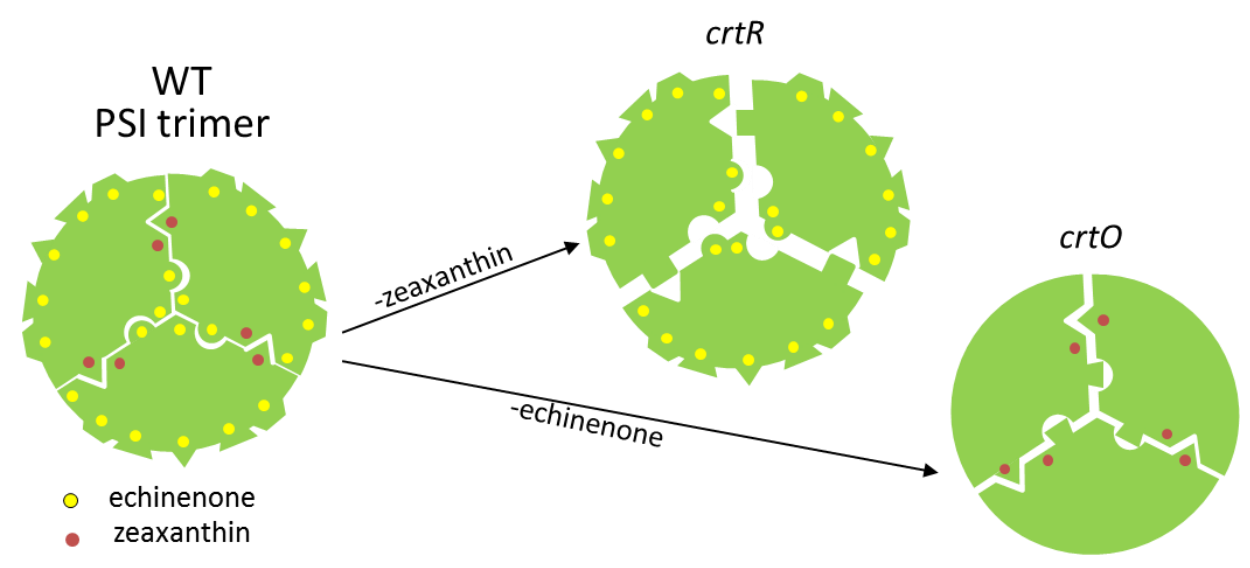

We have monitored the organization of PSI trimer upon xanthophyll deficiency in vivo and in vitro as well. The spectroscopic methods used in this study are based on specific pigment-protein and pigment-pigment interactions within the PSI complex. One of our methods, the circular dichroism, showed that only the absence of zeaxanthin resulted in a noticeable change in the in vivo PSI trimer signal. On the other hand, the absence of echinenone, much more than that of zeaxanthin, led to a reduced level of LWC fluorescence. These LWCs are present at the PSI trimeric complex in a higher amount. These results showed that both $\mathrm{x}$ have specific and not interchangeable roles in the structural organization of PSI trimer in vivo. 
The further biochemical investigations were performed to study the influence of specific xanthophylls in the organization of PSI. The poor resolution of monomeric PSI bands was observed in the xanthophyll deficient mutants, but this effect was eliminable by higher detergent concentration. Thus, we presume a modified interaction of monomers with the surrounding lipids upon xanthophyll-deficiency. A most conspicuous result was the propensity of PSI trimers to disassemble into monomers in the absence of xanthophylls upon treatment by a chelating agent, ethylenediaminetetraacetic acid (EDTA). We propose that the structural differences in the monomer-monomer interface of the protein probably led to an easier removal of the important $\mathrm{Ca}^{2+}$ upon xanthophyll deficiency.

The xanthophylls-related spectral differences were also detected in the isolated PSI trimers, which prove that the monomerization is not the only change brought about the lack of xanthophylls. It also predicts the specific sites for the xanthophylls at the PSI complex. A more rigorous purification protocol was able to eliminate the spectral difference between wild-type and xanthophyll deficient PSI trimers. This finding led to the proposition that the xanthophylls are either closely associated or present in the peripheral part of the PSI complex and can also interact with the surrounding lipid matrix. We propose that xanthophylls are performing mostly fine regulation of the PSI structure. It is rather surprising because xanthophylls were not considered to have a vital structural role in the photosynthetic complexes of cyanobacteria. It is noteworthy that based on this work the presence of xanthophylls in PSI presumes has been supported by the very recently published partial structure of Synechocystis PSI trimer. This high-resolution crystal structure reveals that the PSI complex contains both zeaxanthin and echinenone.

We also observed a low number of zeaxanthin and echinenone molecules in the PSI complexes of $T$. elongatus. The stability of the PSII complexes is also influenced by the 
absence of xanthophylls, based on the previous work in our laboratory. It seems that the structural function of xanthophylls for photosystems could be a more general phenomenon, not only specific for Synechocystis species or PSI. 


\section{6. ÖSSZEFOGLALÓ}

A jelen tézis a karotinoidok szerkezeti jelentőségét vizsgálja biokémiai és biofizikai módszerekkel a Synechocystis sp. PCC 6803 (Synechocystis) cianobaktérium fénybegyüjtő fikobiliszóma (FB) antennájának és az első fotokémiai rendszerének (PS1) szerveződésében és müködésében. A cianobaktériumok széles körben tanulmányozott és nagy jelentőséggel bíró fotoszintetikus szervezetek. Kiemelkedő jelentőségüek az elsődleges biomassza termelésben és taxonómiailag közel állnak a mai oxigéntermelő fotoszintetikus szervezetek őseihez. A prokarióták között egyedül a cianobaktériumok oxigénfejlesztők, genetikailag is könnyen módosíthatóak és az ipar számára potenciálisan felhasználható biomassza vagy bioüzemanyag termelők.

\section{i. $\quad$ A $\beta$-karotin befolyásolja a fikobiliszóma antenna szerkezetét}

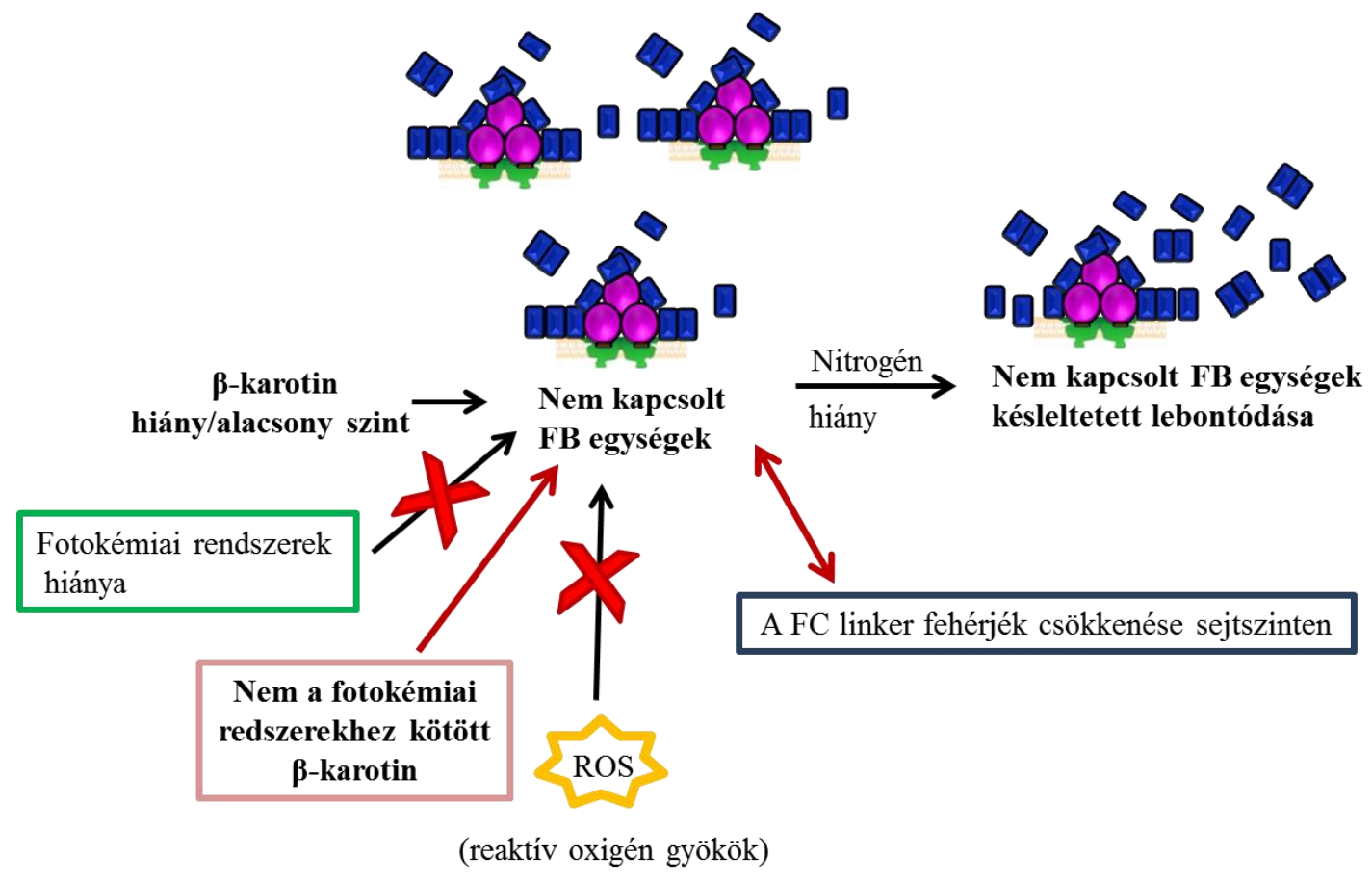

A tézis első részében a karotinoidösszetétel és a FB antenna szerveződése közötti összefüggést vizsgáltam. Korábban megfigyelték, hogy a teljes karotinoidhiány ( $c r t B$ sejt) és 
az alacsony karotinoid szint ( $c r t H$ sejt) is szabadon álló, FB-hoz nem kapcsolt fikocianin (FC) FB alegységek, valamint kevesebb FC egységet tartalmazó FBk megjelenéséhez vezet. Tanulmányoztunk számos mutáns vonalat és előállítottunk egy teljes mixoxantofillhiányos mutánst (cruF, jelen tézisben). Méréseinkkel megerősítettük, hogy egyik xantofill sem befolyásolja jelentősen a FB szerkezetét, tehát egyedül a $\beta$-karotin hiánya felelős a nemkapcsolt FC egységek jelenlétéért. Az általánosságban ismert, hogy a legtöbb $\beta$-karotin molekula a fotokémiai rendszerekhez kötve található a sejtben. Ugyanakkor, a fotokémiai rendszerek hiánya, ami a karotinoidhiányos sejtekre is jellemző, nem befolyásolta a FB szerkezetét az elvégzett kísérletekben. Valószínűleg egy kis mennyiségü, nem a fotokémiai rendszerekhez kötött $\beta$-karotin szükséges a FB megfelelő szerveződéséhez.

A nem-kapcsolt FC egységek megjelenése magyarázható a FC alegységeket a FB többi részéhez csatoló linker fehérjék hiányával vagy nem megfelelő müködésével. A teljes karotinoidhiányos mutánssal végzett kísérleteink azt mutatják, hogy a FC linkerek mennyisége sejtszinten és a tisztított FB-ban egyaránt alacsonyabb volt. Következésképpen, karotinoidok hiányában a módosult FB szerkezet valószínüleg a linker fehérjék nagyobb mértékü lebontódásának vagy az azok szintézisében bekövetkező zavarnak a következménye.

A teljes karotinoidhiányos (crtB) mutáns extrém fényérzékeny és fotoszintetikus aktivitással sem rendelkezik. Ugyanakkor, az alacsonyabb karotinoidtartalommal rendelkező sejtek $(c r t H)$ az alapvető fotoszintetikus funkciók nagymértékü zavara nélkül tartalmazzák ugyanazt a FB szerkezeti zavart, mint a teljes karotinoidhiányos mutáns $(\operatorname{crtB})$. Ezért a további kísérleteinkben túlnyomórészt az alacsonyabb karotinoidtartalommal rendelkező mutáns sejteket használtuk a $\beta$-karotin és a FB szerkezet kapcsolatának feltárására, a modellrendszerünk komplexitásának csökkentése érdekében. 
A karotinoidok egyik legfontosabb szerepe a reaktív oxigén gyökök (ROS) elleni védelem. Tehát csökkent $\beta$-karotin szint esetén felmerül a ROS által indukált direkt FB károsodás lehetősége. Kísérleteinkben az alacsonyabb karotinoidtartalommal rendelkező sejtek $(\operatorname{crtH})$ megnövekedett szinglet oxigén $\left({ }_{1} \mathrm{O}^{2}\right)$ termelödést mutattak, amely egy igen reaktív ROS. Ezek a sejtek továbbá érzékenyebbnek bizonyultak az erős fénnyel szemben is. Ugyanakkkor a mutáns sejtben, magas fényintenzitások mellett, erősebb tendenciát figyeltünk meg a teljes FB lebontódására, mint a szabadon álló FC alegységek további felhalmozódására. Habár a mutáns sejtek alacsonyabb karotinoidtartalommal rendelkeznek, mégis a vad típushoz hasonló mennyiségü mixoxantofill található bennük. A mutánsban jelenlévő mixoxantofill képes lehet a PB linker fehérjéinek a ROS elleni védelmét részlegesen ellátni. Ezt a hipotézist kizártuk az általunk az alacsony karotinoidtartalommal rendelkező sejtekből létrehozott, mixoxantofill bioszintézisére sem képes kettős mutáns (cruF/crtH, jelen tézis) vizsgálatával. Ezen eredmények alapján azt feltételezzük, hogy nem a ROS-k okozta direkt károsodás a felelös a FC linker fehérjék mennyiségének csökkenéséért korlátozott $\beta$-karotin hozzáférhetőség esetén.

Következő megközelítési módként a FB-k nitrogénhiány által indukált enzimatikus lebontását használtuk a nem kapcsolt FC alegységeket tartalmazó sejtek (crtB és $\operatorname{crtH}$ ) esetében. Korlátozott nitrogén forrás esetében a vad típusú sejtek a saját fikobiliproteinjeik programozott lebontásából nyernek vissza szükséges anyagokat a túlélésük érdekében. Meglepő módon, a kísérleteinkben a nem-kapcsolt FC egységek alacsonyabb lebontódási sebességét figyeltük meg a mutáns sejtekben. Ezért feltételezzük, hogy a FC egységek lassabb lebontása vagy a FB-k fokozott szétesése okozza a nem-kötött FC egységek feldúsulását $\beta$-karotin korlátozottság esetén. 


\section{ii. A zeaxantin és az echinenon módosítja az elsö fotokémiai rendszer trimerének szerkezetét}

Dolgozatom második felében a xantofilloknak a PS1 trimer szerveződésében játszott szerepét vizsgáltuk meg. Az általunk végzett pigmentanalízis zeaxantin és echinenon molekulák jelenlétét mutatta ki a tisztított PS1 komplex esetében. Tehát a zeaxantin és az echinenon pigmentek a komplex részei, vagy a membránba ágyazva a PS1 komplex közvetlen közelében helyezkednek el. A mixoxantofillt azonban a sejtben jelenlevő nagy mennyisége ellenére sem tudtuk kimutatni a PS1 komplexben, vagyis csak bizonyos xantofill molekulák vannak jelen a PS1-ben. A xantofillhiányos sejtek PS1 komplexében a $\beta$-karotin molekulák számának növekedését figyeltünk meg, ami arra utal, hogy a xantofillok fontos szerepet játszhatnak a PS1-ben.

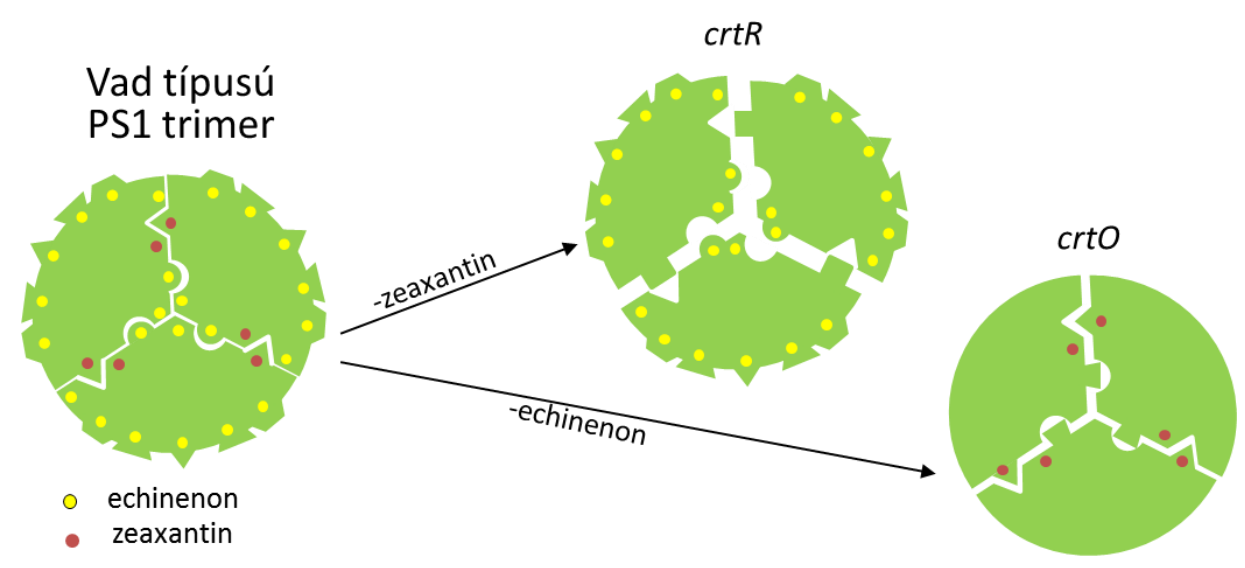

Megvizsgáltuk a xantofillek szerepét a PS1 trimer szerveződésében spektroszkópiai módszerekkel in vivo és in vitro is. Ezek a módszerek a PS1 komplexben levő specifikus pigment-fehérje vagy pigment-pigment kölcsönhatásokon alapulnak. Az egyik módszerünk, a cirkuláris dikroizmus, azt mutatta, hogy csak a zeaxantin hiánya okozott számottevő változást az in vivo PS1 trimer jelében. A másik módszer azt az eredményt adta, hogy a zeaxantin nem, de az echinenon hiánya csökkenti a hosszú-hullámhosszú klorofillok (LWC) 
fluoreszcenciáját a PS1 komplexben. Ezek a LWC-k a PS1 trimerben nagyobb mennyiségben vannak jelen mint a monomerben. A különböző xantofillek hiányának látszólag ellentmondásos hatása a PS1 komplex szerkezetére arra utal, hogy a mind a zeaxantin, mind az echinenon képes befolyásolni a PS1 komplexet in vivo körülmények között, méghozzá specifikus módon.

További biokémiai vizsgálatokat végeztünk a különböző xantofillek PS1-ben betöltött specifikus szerepének tisztázására. Natív gélelektroforézis segítségével rosszul elválasztódó monomer PS1 sávot kaptunk a xantofillhiányos mintákban. Ezt a hatást azonban képesek voltunk magasabb detergens koncentráció használatával megszüntetni. Ezen eredmények alapján feltételezzük a PS1 fehérjéi és az őket körülvevő lipidek közti fehérje-lipid kölcsönhatások zavarát a xantofilllhiányos mutánsban.

A legszembetűnőbb eredmény a teljes xantofillhiányos mutánsból izolált PS1 trimerek monomerekké szétesése a kelátképző etilén-diamin-tetraecetsav (EDTA) kezelés hatására. Az eredményeink alapján azt tételezzük fel, hogy a xantofillok hiányában létrejövő szerkezeti módosulás a monomer-monomer határon levő kiemelkedő jelentőségű $\mathrm{Ca}^{2+}$ ion gyengébb kötődését eredményezi.

A xantofillfüggő spektrális különbségek az izolált PS1-ben is megfigyelhetőek voltak, ami arra utal, hogy a monomerizáció nem az egyetlen változás, amit a xantofillek előidéznek. Továbbá, feltételezi specifikus xantofillkötő helyek jelenlétét a PSI komplexben. A vad típusú és xantofillhiányos PS1 trimer közötti szerkezeti különbség képes eltünni a soklépéses tisztítási eljárás során. Ennek eredményeképp arra következtettünk, hogy a xantofillok a komplex membránhoz közel eső részén helyezkednek el a fehérjébe ágyazódva, vagy annak közvetlen közelében, ahol képesek kölcsönhatni a komplexet körülvevő lipidmolekulákkal. Feltételezhető tehát, hogy a xantofillek főleg a PS1 szerkezetének finom 
szabályozásában játszanak szerepet. Ezen feltételezés meglepő annak függvényében, hogy a xantofilleknek nem tulajdonítottak kiemelkedő szerepet a cianobakteriumok fotoszintetikus komplexeiben.

Figyelemre méltó, hogy a jelen munka eredményeként a PS1-ben feltételezett xantofillek jelenlétét a közelmúltban a Synechocystisböl nyert részleges PS1 trimer szerkezetben is kimutatták. A nagyfelbontású kristályszerkezet alapján tudjuk, hogy mind zeaxantin mind echinenon molekula detektálható a PS1 trimer komplexben. Továbbá kis mennyiségü zeaxantin és echinenon molekulát a Thermosynechococcus elongatus PS1 monomerében is megfigyeltünk. A csoportunkban elért korábbi eredmények azt mutatják, hogy a xantofillok hiánya a PS2 szerkezetét is képes befolyásolni. Ez arra enged következtetni, hogy a xantofillok szerkezetet befolyásoló szerepe egy általánosabb jelenség és nem kizárólag a Synechocystis fajokra vagy a PS1-re jellemző. 


\section{CONCLUSIONS}

We confirmed the role of carotenoids in the photosynthetic pigment-protein complexes:

i) PBS and ii) PSI trimeric complex of Synechocystis.

\section{Role of carotenoids in the PBS structure}

- The non-photosystem bound $\beta$-carotene population is important for the assembly of PBS.

- The carotenoid deficiency also resulted in a reduced cellular level of rod linker proteins which explains the presence of unconnected rods of PBS.

- In spite of the reduced antioxidant protection of the cell, ROS induced direct damage did not seem to affect the phycobiliproteins or rod linkers of a cell possessing limited $\beta$ carotene.

- The enzymatic PBS degradation induced by nitrogen starvation demonstrated a slower degradation of the unconnected PC units.

- We propose that an insufficient degradation rate of phycobiliproteins and/or an increased disassembly of PBS occur under the limited $\beta$-carotene availability.

\section{Effect of xanthophylls on the PSI trimer}

- We confirmed the presence of two kinds of xanthophylls, zeaxanthin and echinenone in the PSI trimeric complex. These xanthophylls should be part of the complex or be embedded in the membrane in the vicinity of PSI.

- Both of these PSI-associated xanthophylls appeared to be structurally important and perform specific structural modifications in the PSI complex.

- Although zeaxanthin is present at a much lower level in the isolated PSI complex, it is structurally more important than echinenone for maintaining the trimeric PSI complex. 
- We propose that xanthophylls are important for the fine-tuning of the PSI trimer. 


\section{REFERENCES}

Adir N. 2005. Elucidation of the molecular structures of components of the phycobilisome: reconstructing a giant. Photosynth. Res. 85: 15-32

Anderson JM, Horton P, Kim EH, Chow WS. 2012. Towards elucidation of dynamic structural changes of plant thylakoid architecture. Phil. Trans. R. Soc. B 367: 3515-24

Anderson LK, Toole CM. 1998. A model for early events in the assembly pathway of cyanobacterial phycobilisomes. Mol. Microbiol. 30: 467-74

Arteni AA, Ajlani G, Boekema EJ. 2009. Structural organisation of phycobilisomes from Synechocystis sp strain PCC6803 and their interaction with the membrane. Biochim. Biophys. Acta 1787: 272-79

Ashby MK, Mullineaux CW. 1999. The role of ApcD and ApcF in energy transfer from phycobilisomes to PSI and PSII in a cyanobacterium. Photosynth. Res. 61: 169-79

Ashikawa I, Miyata A, Koike H, Inoue Y, Koyama Y. 1986. Light-induced structuralchange of beta-carotene in thylakoid membranes. Biochemistry 25: 6154-60

Baier A, Winkler W, Korte T, Lockau W, Karradt A. 2014. Degradation of phycobilisomes in Synechocystis sp. PCC6803: evidence for essential formation of an NblA1/NblA2 heterodimer and its codegradation by A Clp protease complex. J. Biol. Chem. 289: 11755-66

Barber J, Nield J, Morris EP, Zheleva D, Hankamer B. 1997. The structure, function and dynamics of photosystem two. Physiol. Plant. 100: 817-27

Bautista JA, Rappaport F, Guergova-Kuras M, Cohen RO, Golbeck JH, Wang JY, Beal D, Diner BA. 2005. Biochemical and biophysical characterization of photosystem I from phytoene desaturase and $\zeta$-carotene desaturase deletion mutants of Synechocystis sp PCC 6803. J. Biol. Chem. 280: 20030-41

Bernát G, Waschewski N, Rögner M. 2009. Towards efficient hydrogen production: the impact of antenna size and external factors on electron transport dynamics in Synechocystis PCC 6803. Photosynth. Res. 99: 205-16

Bersanini L, Battchikova N, Jokel M, Rehman A, Vass I, Allahverdiyeva Y, Aro EM. 2014. Flavodiiron protein Flv2/Flv4-related photoprotective mechanism dissipates excitation pressure of PSII in cooperation with phycobilisomes in cyanobacteria. Plant Physiol. 164: 805-18

Blankenship RE, Chen M. 2013. Spectral expansion and antenna reduction can enhance photosynthesis for energy production. Curr. Opin. Chem. Biol. 17: 457-61

Boekema EJ, Hankamer B, Bald D, Kruip J, Nield J, Boonstra AF, Barber J, Rogner M. 1995. Supramolecular structure of the Photosystem II complex from green plants and cyanobacteria. Proc. Natl. Acad. Sci. U.S.A. 92: 175-79 
Bradford MM. 1976. A rapid and sensitive method for the quantitation of microgram quantities of protein utilizing the principle of protein-dye binding. Anal. Biochem. 72: 248-54

Chang L, Liu X, Li Y, Liu CC, Yang F, Zhao J, Sui SF. 2015. Structural organization of an intact phycobilisome and its association with photosystem II. Cell Res. 25: 726-37

Chegeni FA, Perin G, Gupta KBSS, Simionato D, Morosinotto T, Pandit A. 2016. Protein and lipid dynamics in photosynthetic thylakoid membranes investigated by in-situ solid-state NMR. Biochim. Biophys. Acta 1857: 1849-59

Chitnis VP, Chitnis PR. 1993. PsaL subunit is required for the formation of photosystem I trimers in the cyanobacterium Synechocystis sp PCC 6803. FEBS Lett. 336: 330-34

Collier JL, Grossman AR. 1994. A small polypeptide triggers complete degradation of light-harvesting phycobiliproteins in nutrient-deprived cyanobacteria. EMBO J. 13: 1039-47

Coufal J, Hladik J, Sofrova D. 1989. The carotenoid content of photosystem I pigmentprotein complexes of the cyanobacterium Synechococcus elongatus. Photosynthetica 23: $603-16$

Croce R, Morosinotto T, Castelletti S, Breton J, Bassi R. 2002. The Lhca antenna complexes of higher plants photosystem I. Biochim. Biophys. Acta 1556: 29-40

Daddy S, Zhan J, Jantaro S, He C, He Q, Wang Q. 2015. A novel high light-inducible carotenoid-binding protein complex in the thylakoid membranes of Synechocystis PCC 6803. Sci Rep-Uk 5: 1-8

Dall'Osto L, Piques M, Ronzani M, Molesini B, Alboresi A, Cazzaniga S, Bassi R. 2013. The Arabidopsis nox mutant lacking carotene hydroxylase activity reveals a critical role for xanthophylls in photosystem I biogenesis. Plant Cell 25: 591-608

Domonkos I, Kis M, Gombos Z, Ughy B. 2013. Carotenoids, versatile components of oxygenic photosynthesis. Prog. Lipid Res. 52: 539-61

Domonkos I, Malec P, Laczko-Dobos H, Sozer O, Klodawska K, Wada H, Strzalka K, Gombos Z. 2009. Phosphatidylglycerol depletion induces an increase in myxoxanthophyll biosynthetic activity in Synechocystis PCC 6803 Cells. Plant Cell Phys. 50: 374-82

Eberhard S, Finazzi G, Wollman FA. 2008. The dynamics of photosynthesis. Annu. Rev. Genet. 42: 463-515

El-Mohsnawy E, Kopczak MJ, Schlodder E, Nowaczyk M, Meyer HE, Warscheid B, Karapetyan NV, Rögner M. 2010. Structure and function of intact photosystem I monomers from the cyanobacterium Thermosynechococcus elongatus. Biochemistry 49: 4740-51 
Ermakova-Gerdes S, Shestakov S, Vermaas WFJ. 1995. Development of a photosystem Iless strain of Synechocystis sp. PCC 6803 for analysis of mutations in the photosystem II proteins D2 and CP43 In Photosynthesis: From Biology to Biosphere, ed. P Mathis, pp. 483-86. Dordrecht: Kluwer

Fiore A, Dall'Osto L, Cazzaniga S, Diretto G, Giuliano G, Bassi R. 2012. A quadruple mutant of Arabidopsis reveals a beta-carotene hydroxylation activity for LUT1/CYP97C1 and a regulatory role of xanthophylls on determination of the PSI/PSII ratio. BMC Plant Biol. 12: 1-15

Frank HA, Cogdell RJ. 1996. Carotenoids in photosynthesis. Photochem. Photobiol. 63: 257-64

Friebe VM, Millo D, Swainsbury DJK, Jones MR, Frese RN. 2017. Cytochrome c Provides an Electron-Funneling Antenna for Efficient Photocurrent Generation in a Reaction Center Biophotocathode. ACS Appl. Mater. Inter. 9: 23379-88

Fromme P, Jordan P, Krauss N. 2001. Structure of photosystem I. Biochim. Biophys. Acta 1507: 5-31

Fromme P, Witt HT. 1998. Improved isolation and crystallization of Photosystem I for structural analysis. Biochim. Biophys. Acta 1365: 175-84

Gobets B, van Grondelle R. 2001. Energy transfer and trapping in photosystem I. Biochim. Biophys. Acta 1507: 80-99

Gobets B, van Stokkum IH, Rogner M, Kruip J, Schlodder E, Karapetyan NV, Dekker JP, van Grondelle R. 2001. Time-resolved fluorescence emission measurements of photosystem I particles of various cyanobacteria: a unified compartmental model. Biophys. J. 81: 407-24

Grotjohann I, Fromme P. 2005. Structure of cyanobacterial photosystem I. Photosynth. Res. 85: 51-72

Gruszecki WI, Strzalka K. 2005. Carotenoids as modulators of lipid membrane physical properties. Biochim. Biophys. Acta 1740: 108-15

Gunerken E, D'Hondt E, Eppink MHM, Garcia-Gonzalez L, Elst K, Wijffels RH. 2015. Cell disruption for microalgae biorefineries. Biotechnol. Adv. 33: 243-60

Guskov A, Kern J, Gabdulkhakov A, Broser M, Zouni A, Saenger W. 2009. Cyanobacterial photosystem II at 2.9-angstrom resolution and the role of quinones, lipids, channels and chloride. Nat. Struct. Mol. Biol. 16: 334-42

Hakkila K, Antal T, Rehman AU, Kurkela J, Wada H, Vass I, Tyystjarvi E, Tyystjarvi T. 2014. Oxidative stress and photoinhibition can be separated in the cyanobacterium Synechocystis sp. PCC 6803. Biochim. Biophys. Acta 1837: 217-25

He JA, Hu YZ, Jiang LJ. 1997. Photodynamic action of phycobiliproteins: In situ generation of reactive oxygen species. Biochim. Biophys. Acta 1320: 165-74 
Hiyama T, Nishimura M, Chance B. 1969. Determination of carotenes by thin-layer chromatography. Anal. Biochem. 29: 339-42

Hohmann-Marriott MF, Blankenship RE. 2011. Evolution of Photosynthesis. Annu. Rev. Plant Biol. 62: 515-48

Janik E, Bednarska J, Zubik M, Sowinski K, Luchowski R, Grudzinski W, Matosiuk D, Gruszecki WI. 2016. The xanthophyll cycle pigments, violaxanthin and zeaxanthin, modulate molecular organization of the photosynthetic antenna complex LHCII. Arch. Biochem. Biophys. 592: 1-9

Jordan P, Fromme P, Witt HT, Klukas O, Saenger W, Krauss N. 2001. Threedimensional structure of cyanobacterial photosystem I at 2.5 angstrom resolution. Nature 411: 909-17

Karapetyan NV, Bolychevtseva YV, Yurina NP, Terekhova IV, Shubin VV, Brecht M. 2014. Long-wavelength chlorophylls in photosystem I of cyanobacteria: Origin, localization, and functions. Biochemistry 79: 213-20

Karapetyan NV, Holzwarth AR, Rögner M. 1999. The photosystem I trimer of cyanobacteria: molecular organization, excitation dynamics and physiological significance. FEBS Lett. 460: 395-400

Karradt A, Sobanski J, Mattow J, Lockau W, Baier K. 2008. NblA, a key protein of phycobilisome degradation, interacts with ClpC, a HSP100 chaperone partner of a cyanobacterial Clp protease. J. Biol. Chem. 283: 32394-403

Klodawska K, Kovacs L, Varkonyi Z, Kis M, Sozer O, Laczko-Dobos H, Kobori O, Domonkos I, Strzalka K, Gombos Z, Malec P. 2015. Elevated growth temperature can enhance photosystem I trimer formation and affects xanthophyll biosynthesis in cyanobacterium Synechocystis sp. PCC6803 Cells. PCP 56: 558-71

Knoppova J, Sobotka R, Tichy M, Yu J, Konik P, Halada P, Nixon PJ, Komenda J. 2014. Discovery of a chlorophyll binding protein complex involved in the early steps of photosystem II assembly in Synechocystis. Plant Cell 26: 1200-12

Komenda J, Reisinger V, Muller BC, Dobakova M, Granvogl B, Eichacker LA. 2004. Accumulation of the D2 protein is a key regulatory step for assembly of the photosystem II reaction center complex in Synechocystis PCC 6803. J. Biol. Chem. 279: 48620-29

Komenda J, Sobotka R. 2016. Cyanobacterial high-light-inducible proteins - Protectors of chlorophyll-protein synthesis and assembly. Biochim. Biophys. Acta 1857: 288-95

Kopecna J, Komenda J, Bucinska L, Sobotka R. 2012. Long-term acclimation of the cyanobacterium Synechocystis sp PCC 6803 to high light is accompanied by an 
enhanced production of chlorophyll that is preferentially channeled to trimeric Photosystem I. Plant Physiol. 160: 2239-50

Kothe T, Poller S, Zhao FY, Fortgang P, Rogner M, Schuhmann W, Plumere N. 2014. Engineered electron-transfer chain in Photosystem I based photocathodes outperforms electron-transfer rates in natural photosynthesis. Chem.-Eur. J. 20: 11029-34

Krieger-Liszkay A, Fufezan C, Trebst A. 2008. Singlet oxygen production in photosystem II and related protection mechanism. Photosynth Res 98: 551-64

Kruip J, Bald D, Boekema E, Rogner M. 1994. Evidence for the existence of trimeric and monomeric photosystem-I complexes in thylakoid membranes from cyanobacteria. Photosynth. Res. 40: 279-86

Kusama Y, Inoue S, Jimbo H, Takaichi S, Sonoike K, Hihara Y, Nishiyama Y. 2015. Zeaxanthin and echinenone protect the repair of photosystem II from inhibition by singlet oxygen in Synechocystis sp. PCC 6803. Plant Cell Phys. 56: 906-16

Lagarde D, Vermaas W. 1999. The zeaxanthin biosynthesis enzyme beta-carotene hydroxylase is involved in myxoxanthophyll synthesis in Synechocystis sp. PCC 6803. FEBS Lett. 454: 247-51

Lamberg P, Bren KL. 2016. Extracellular electron transfer on sticky paper electrodes: Carbon paste paper anode for microbial fuel cells. Acs Energy Lett 1: 895-98

Latifi A, Ruiz M, Zhang CC. 2009. Oxidative stress in cyanobacteria. FEMS Microbiol. Rev. 33: $258-78$

Liu LN, Chen XL, Zhang YZ, Zhou BC. 2005a. Characterization, structure and function of linker polypeptides in phycobilisomes of cyanobacteria and red algae: An overview. Biochim. Biophys. Acta 1708: 133-42

Liu XG, Zhao JJ, Wu QY. 2005b. Oxidative stress and metal ions effects on the cores of phycobilisomes in Synechocystis sp PCC 6803. FEBS Lett. 579: 4571-76

MacColl R. 1998. Cyanobacterial Phycobilisomes. J. Struct. Biol. 124: 311-34

Malavath T, Caspy I, Netzer-EI SY, Klaiman D, Nelson N. 2018. Structure and function of wild-type and subunit-depleted photosystem I in Synechocystis. Biochim. Biophys. Acta

Mantoura RFC, Llewellyn CA. 1983. The rapid-determination of algal chlorophyll and carotenoid-pigments and their breakdown products in natural-waters by reverse-phase high-performance liquid-chromatography. Anal. Chim. Acta 151: 297-314

Masamoto K, Hisatomi S, Sakurai I, Gombos Z, Wada H. 2004. Requirement of carotene isomerization for the assembly of photosystem II in Synechocystis sp PCC 6803. Plant Cell Phys. 45: 1325-29 
Masamoto K, Misawa N, Kaneko T, Kikuno R, Toh H. 1998. Beta-carotene hydroxylase gene from the cyanobacterium Synechocystis sp. PCC6803. Plant Cell Phys. 39: 56064

Masamoto K, Wada H, Kaneko T, Takaichi S. 2001. Identification of a gene required for cis-to-trans carotene isomerization in carotenogenesis of the cyanobacterium Synechocystis sp PCC 6803. Plant Cell Phys. 42: 1398-402

Mayer MP. 1995. A new set of useful cloning and expression vectors derived from pBlueScript. Gene 163: 41-46

Mazor Y, Nataf D, Toporik H, Nelson N. 2014. Crystal structures of virus-like photosystem I complexes from the mesophilic cyanobacterium Synechocystis PCC 6803. Elife 3: 117

Meeks JC, Castenholz RW. 1971. Growth and photosynthesis in an extreme thermophile, Synechococcus lividus (Cyanophyta). Arch. Microbiol. 78: 25-41

Melnicki MR, Leverenz RL, Sutter M, Lopez-Igual R, Wilson A, Pawlowski EG, Perreau F, Kirilovsky D, Kerfeld CA. 2016. Structure, diversity, and evolution of a new family of soluble carotenoid binding proteins in Cyanobacteria. Molecular Plant 9: 1379-94

Narainsamy K, Cassier-Chauvat C, Junot C, Chauvat F. 2013. High performance analysis of the cyanobacterial metabolism via liquid chromatography coupled to a LTQOrbitrap mass spectrometer: evidence that glucose reprograms the whole carbon metabolism and triggers oxidative stress. Metabolomics 9: 21-32

Nishiyama Y, Yamamoto H, Allakhverdiev SI, Inaba M, Yokota A, Murata N. 2001. Oxidative stress inhibits the repair of photodamage to the photosynthetic machinery. EMBO J. 20: 5587-94

Palsson LO, Flemming C, Gobets B, van Grondelle R, Dekker JP, Schlodder E. 1998. Energy transfer and charge separation in photosystem I: P700 oxidation upon selective excitation of the long-wavelength antenna chlorophylls of Synechococcus elongatus. Biophys. J. 74: 2611-22

Rakhimberdieva MG, Boichenko VA, Karapetyan NV, Stadnichuk IN. 2001. Interaction of phycobilisomes with photosystem II dimers and photosystem I monomers and trimers in the cyanobacterium Spirulina platensis. Biochemistry 40: 15780-88

Reguera G, Nevin KP, Nicoll JS, Covalla SF, Woodard TL, Lovley DR. 2006. Biofilm and nanowire production leads to increased current in Geobacter sulfurreducens fuel cells. Appl. Environ. Microbiol. 72: 7345-8

Reguera G, Pollina RB, Nicoll JS, Lovley DR. 2007. Possible nonconductive role of Geobacter sulfurreducens pilus nanowires in biofilm formation. J. Bacteriol. 189: 2125-7 
Rehman AU, Cser K, Sass L, Vass I. 2013. Characterization of singlet oxygen production and its involvement in photodamage of photosystem II in the cyanobacterium Synechocystis PCC 6803 by histidine-mediated chemical trapping. Biochim. Biophys. Acta 1827: 689-98

Richaud C, Zabulon G, Joder A, Thomas JC. 2001. Nitrogen or sulfur starvation differentially affects phycobilisome degradation and expression of the NblA gene in Synechocystis strain PCC 6803. J. Bacteriol. 183: 2989-94

Rinalducci S, Pedersen JZ, Zolla L. 2008. Generation of reactive oxygen species upon strong visible light irradiation of isolated phycobilisomes from Synechocystis PCC 6803. Biochim. Biophys. Acta 1777: 417-24

Rogner M, Muhlenhoff U, Boekema EJ, Witt HT. 1990. Monomeric, dimeric and trimeric PSI reaction center complexes isolated from the thermophilic cyanobacterium Synechococcus sp - size, shape and activity. Biochim. Biophys. Acta 1015: 415-24

Ryu JY, Song JY, Lee JM, Jeong SW, Chow WS, Choi SB, Pogson BJ, Park YI. 2004. Glucose-induced expression of carotenoid biosynthesis genes in the dark is mediated by cytosolic $\mathrm{pH}$ in the cyanobacterium Synechocystis sp. PCC 6803. J. Biol. Chem. 279: $25320-25$

Santabarbara S, Casazza AP, Ali K, Economou CK, Wannathong T, Zito F, Redding KE, Rappaport F, Purton S. 2013. The requirement for carotenoids in the assembly and function of the photosynthetic complexes in Chlamydomonas reinhardtii. Plant Physiol. 161: 535-46

Sarma MK, Kaushik S, Goswami P. 2016. Cyanobacteria: A metabolic power house for harvesting solar energy to produce bio-electricity and biofuels. Biomass. Bioenergy 90: 187-201

Sato T, Minagawa S, Kojima E, Okamoto N, Nakamoto H. 2010. HtpG, the prokaryotic homologue of Hsp90, stabilizes a phycobilisome protein in the cyanobacterium Synechococcus elongatus PCC 7942. Mol. Microbiol. 76: 576-89

Schafer L, Vioque A, Sandmann G. 2005. Functional in situ evaluation of photo synthesisprotecting carotenoids in mutants of the cyanobacterium Synechocystis PCC 6803. J. Photochem. Photobiol. B: Biol. 78: 195-201

Schwarz R, Forchhammer K. 2005. Acclimation of unicellular cyanobacteria to macronutrient deficiency: emergence of a complex network of cellular responses. Microbiology 151: 2503-14

Sedoud A, Lopez-Igual R, Rehman AU, Wilson A, Perreau F, Boulay C, Vass I, Krieger-Liszkay A, Kirilovsky D. 2014. The cyanobacterial photoactive orange carotenoid protein is an excellent singlet oxygen quencher. Plant Cell 26: 1781-91 
Sendersky E, Kozer N, Levi M, Garini Y, Shav-Tal Y, Schwarz R. 2014. The proteolysis adaptor, NblA, initiates protein pigment degradation by interacting with the cyanobacterial light-harvesting complexes. Plant J. 79: 118-26

Sendersky E, Kozer N, Levi M, Moizik M, Garini Y, Shav-Tal Y, Schwarz R. 2015. The proteolysis adaptor, NblA, is essential for degradation of the core pigment of the cyanobacterial light-harvesting complex. Plant J. 83: 845-52

Shubin VV, Tsuprun VL, Bezsmertnaya IN, Karapetyan NV. 1993. Trimeric forms of the photosystem I reaction center complex pre-exist in the membranes of the cyanobacterium Spirulina platensis. FEBS Lett. 334: 79-82

Six C, Joubin L, Partensky F, Holtzendorff J, Garczarek L. 2007. UV-induced phycobilisome dismantling in the marine picocyanobacterium Synechococcus sp. WH8102. Photosynth Res 92: 75-86

Sonoike K, Hihara Y, Ikeuchi M. 2001. Physiological significance of the regulation of photosystem stoichiometry upon high light acclimation of Synechocystis sp. PCC 6803. Plant Cell Phys. 42: 379-84

Sozer O, Komenda J, Ughy B, Domonkos I, Laczko-Dobos H, Malec P, Gombos Z, Kis M. 2010. Involvement of carotenoids in the synthesis and assembly of protein subunits of photosynthetic reaction centers of Synechocystis sp. PCC 6803. Plant Cell Phys. 51: 823-35

Takaichi S, Mochimaru M. 2007. Carotenoids and carotenogenesis in cyanobacteria: unique ketocarotenoids and carotenoid glycosides. Cell. Mol. Life Sci. 64: 2607-19

Tamary E, Kiss V, Nevo R, Adam Z, Bernat G, Rexroth S, Roegner M, Reich Z. 2012. Structural and functional alterations of cyanobacterial phycobilisomes induced by high-light stress. Biochim. Biophys. Acta 1817: 319-27

Tian L, van Stokkum IH, Koehorst RB, Jongerius A, Kirilovsky D, van Amerongen H. 2011. Site, rate, and mechanism of photoprotective quenching in cyanobacteria. $J$. Am. Chem. Soc. 133: 18304-11

Toth TN, Chukhutsina V, Domonkos I, Knoppova J, Komenda J, Kis M, Lenart Z, Garab G, Kovacs L, Gombos Z, van Amerongen H. 2015. Carotenoids are essential for the assembly of cyanobacterial photosynthetic complexes. Biochim. Biophys. Acta 1847: 1153-65

Ughy B, Ajlani G. 2004. Phycobilisome rod mutants in Synechocystis sp strain PCC6803. Microbiology 150: 4147-56

Umena Y, Kawakami K, Shen JR, Kamiya N. 2011. Crystal structure of oxygen-evolving photosystem II at a resolution of 1.9 angstrom. Nature 473: 55-U65 
van der Lee J, Bald D, Kwa SL, van Grondelle R, Rogner M, Dekker JP. 1993. Steadystate polarized light spectroscopy of isolated Photosystem I complexes. Photosynth. Res. 35: 311-21

Watanabe M, Ikeuchi M. 2013. Phycobilisome: architecture of a light-harvesting supercomplex. Photosynth. Res. 116: 265-76

Watanabe M, Kubota H, Wada H, Narikawa R, Ikeuchi M. 2011. Novel supercomplex organization of photosystem I in Anabaena and Cyanophora paradoxa. PCP 52: 1628

Xu H, Vavilin D, Funk C, Vermaas W. 2004. Multiple deletions of small cab-like proteins in the cyanobacterium Synechocystis sp PCC 6803 - Consequences for pigment biosynthesis and accumulation. J. Biol. Chem. 279: 27971-79

Yagishita T, Sawayama S, Tsukahara K, Ogi T. 1997. Behavior of glucose degradation in Synechocystis sp. M-203 in bioelectrochemical fuel cells. Bioelectrochem. Bioenerget. 43: $177-80$

Yagishita T, Sawayama S, Tsukahara KI, Ogi T. 1998. Performance of photosynthetic electrochemical cells using immobilized Anabaena variabilis M-3 in discharge/culture cycles. J. Ferment. Bioeng. 85: 546-49

Yu JJ, Wu QY, Mao HB, Zhao NM, Vermaas WFJ. 1999. Effects of chlorophyll availability, on phycobilisomes in Synechocystis sp PCC 6803. IUBMB Life 48: 62530

Zakar T, Herman E, Vajravel S, Kovacs L, Knoppova J, Komenda J, Domonkos I, Kis M, Gombos Z, Laczko-Dobos H. 2017. Lipid and carotenoid cooperation-driven adaptation to light and temperature stress in Synechocystis sp. PCC6803. Biochim. Biophys. Acta 1858: 337-50

Zhu Y, Graham JE, Ludwig M, Xiong W, Alvey RM, Shen G, Bryant DA. 2010. Roles of xanthophyll carotenoids in protection against photoinhibition and oxidative stress in the cyanobacterium Synechococcus sp. strain PCC 7002. Arch. Biochem. Biophys. 504: 86-99

Zolla L, Timperio AM, Walcher W, Huber CG. 2003. Proteomics of light-harvesting proteins in different plant species. Analysis and comparison by liquid chromatography-electrospray ionization mass spectrometry. Photosystem II. Plant Physiol. 131: 198-214

Zouni A, Kern J, Frank J, Hellweg T, Behlke J, Saenger W, Irrgang KD. 2005. Size determination of cyanobacterial and higher plant photosystem II by gel permeation chromatography, light scattering, and ultracentrifugation. Biochemistry 44: 4572-81 


\section{ACKNOWLEDGEMENTS}

I would like to express my sincere gratitude to my supervisors Zoltán Gombos, for providing me the great opportunity and a big support to work in this promising research and Tunde N. Toth whose continuous support and friendly guidance made my Ph.D. work possible and for her great effort to explain things clearly, her patience and motivation that, taken together, she has been a great mentor, a friend, and an inspiration.

My sincere thanks go to Mihály Kis and László Kovács for actively interested in my work and for always available to advise me.

I would like to thank our collaborators Imre Vass, Przemysław Malec, Peter H. Lambrev, Kinga Kłodawska, Ateeq Ur Rehman, Parveen Akhtar, and Sandeesha Kodru for sparing their valuable time and showing me the way ahead. They have been great contributors to the completion of my Ph.D. work.

I would like to express my gratitude to Ildikó Domonkos, Anna Kunné Sallai, Hajnalka Laczkó-Dobos, Tomas Zakar, Éva Hermann and my other colleagues who have been so helpful and co-operative at all times.

A very special gratitude goes to the Research Funds: The National Research, Development and Innovation Office of Hungary NKFIH (K108411 to Z.G, T.N.T. and PD108551 to H.L-D), The Hungarian Governmental Grant (GINOP-2.3.2-15-2016-00001), The Hungarian Ministry for National Economy (GINOP-2.3.2-15-2016-00001), Hungarian Scholarship Board (Balassi Institute), and European Biophysical Societies' Association (EBSA) Bursary for supporting our work. 
My warmest thanks to my family for their moral support. Words cannot express how grateful I am to my family. Thanks a lot for keep supporting me and especially all your prayers for me. And, my beloved grandparents: To them, I dedicate this thesis.

Many thanks to my friends for all the unforgettable memories.

Thank you for all your encouragement. 


\section{LIST OF PUBLICATIONS (MTMT: 10058037)}

\section{Publications included in the thesis}

1. Vajravel S, Kis M, Kłodawska K, Laczko-Dobos H, Malec P, Kovács L, Gombos Z, Toth T.N (2017) Zeaxanthin and echinenone modify the structure of photosystem I trimer in Synechocystis sp. PCC 6803. Biochim. Biophys. Acta 1858(5): 510-518. (IF: 4.93).

2. Vajravel S, Kovács L, Kis M, Rehman A. U, Vass I, Gombos Z, Toth T.N (2016) $\beta$ Carotene influences the phycobilisome antenna of cyanobacterium Synechocystis sp. PCC 6803. Photosynthesis Res 130(1): 403-415. (IF: 3.86).

\section{Other publications}

1. Zakar T, Herman E, Vajravel S, Kovacs L, Knoppová J, Komenda J, Domonkos I, Kis M, Gombos Z, Laczko-Dobos H (2017) Lipid and carotenoid cooperation-driven adaptation to light and temperature stress in Synechocystis sp. PCC6803. Biochim. Biophys. Acta 1858(5): 337-350. (IF: 4.93).

2. Petrova N, Todinova S, Laczko-Dobos H, Zakar T, Vajravel S, Taneva S, Gombos Z, Krumova S (2018) Structural integrity of Synechocystis sp. PCC 6803 phycobilisomes evaluated by means of differential scanning calorimetry. Photosynthesis Res (in-press). (IF: 3.86).

3. Zakar T, Kovacs L, Vajravel S, Herman E, Kis M, Laczko-Dobos H, Gombos Z (2018) Determination of PS I oligomerisation in various cyanobacterial strains and mutants by non-invasive methods. Photosynthetica (in-press). (IF: 1.4). 